\title{
Synthesis and Properties of a Series of Well-defined and Polydisperse Benzo[1,2-b:4,3-b']dithiophene Oligomers
}

Yosuke Nishide, Hideji Osuga,* Masaki Saito, Toshiki Aiba, Yusuke Inagaki, Yuyu Doge, and Kazuhiko Tanaka

Department of Material Science and Chemistry, Faculty of Systems Engineering, Wakayama University, 930 Sakaedani, Wakayama 640-8510, Japan

osuga@sys.wakayama-u. ac.jp

General

Preparation and Characterization Data for 16-41

S3-S14

GPC Chromatograms of $\mathbf{1 1}$ (Figure S1)

S15

LDI-TOF mass spectra of polydisperse oligomers 5, 10 (Figure S2 and S3)

S16

${ }^{1} \mathrm{H}$ NMR and ${ }^{13} \mathrm{C}$ NMR Spectra

S16-S82 


\section{General}

All reactions were carried out under an atmosphere of argon unless otherwise noted. Commercially available anhydrous THF and DMF were used without further purification. Acetonitrile, dichrolomethane, and benzonitrile were distilled from calcium hydride and stored over molecular sieves 4A. Toluene was distilled from sodium and stored over molecular sieves 4A. Hexane solution of nbutyllithium was titrated using diphenylacetic acid. Melting points were determined on a hot stage apparatus and are not corrected. Thin layer chromatography was performed by using precoated silica gel sheets $60 \mathrm{~F}_{254}$. Silica gel (Fuji Silysia PSQ100B) was used for column chromatography. NMR spectra were obtained in $\mathrm{CDCl}_{3}$ and $\mathrm{C}_{6} \mathrm{D}_{5} \mathrm{CD}_{3}$ solution with tetramethylsilane as an internal standard. Cyclic voltammograms (CVs) were recorded in benzonitrile or $\mathrm{CH}_{2} \mathrm{Cl}_{2}$ containing $\mathrm{Bu}_{4} \mathrm{NClO}_{4}(0.1 \mathrm{M})$ as supporting electrolyte at a scan rate of $100 \mathrm{mV} / \mathrm{s}$. Counter and working electrodes were made of $\mathrm{Pt}$, and the reference electrode was $\mathrm{Ag} / \mathrm{AgCl}$. All organic layers of $\mathrm{EL}$ device were prepared by spin coating from toluene. The devices were tested in air under ambient conditions with no encapsulation. 
$\left.b^{\prime}\right]$ dithiophene 15 was prepared using the literature procedure for 4,5-diphenylbenzo[1,2-b:4,3$b^{\prime}$ ]dithiophene (Fischer, E. et al. J. Org. Chem. 1996, 61, 6997-7005). To a stirred solution of 15 (1.00 g, $2.79 \mathrm{mmol})$ in $\mathrm{CH}_{2} \mathrm{Cl}_{2}(10 \mathrm{~mL})$ was added NBS $(0.520 \mathrm{~g}, 2.93 \mathrm{mmol})$ under argon and the mixture was stirred at room temperature for $3 \mathrm{~h}$. After aqueous $\mathrm{Na}_{2} \mathrm{~S}_{2} \mathrm{O}_{3}$ was added, the organic layer was separated. The aqueous layer was extracted with ethyl acetate. The combined organic phases were washed with brine, dried over $\mathrm{Na}_{2} \mathrm{SO}_{4}$ and concentrated. The crude product was purified by silica gel column chromatography (hexane) to give $16(0.955 \mathrm{~g}, 78 \%)$ as a white solid. $\mathrm{mp} 55-59{ }^{\circ} \mathrm{C} ;{ }^{1} \mathrm{H}$ NMR $\left(\mathrm{CDCl}_{3}\right) \delta$ 0.86-0.96 (m, 6H), 1.27-1.79 (m, 16H), 2.83-2.99 (m, 4H), $7.46(\mathrm{~d}, J=5.4 \mathrm{~Hz}, 1 \mathrm{H}), 7.57(\mathrm{~d}$, $J=5.4 \mathrm{~Hz}, 1 \mathrm{H}), 7.65(\mathrm{~s}, 1 \mathrm{H}) ;{ }^{13} \mathrm{C} \mathrm{NMR}\left(\mathrm{CDCl}_{3}\right) \delta .14 .1,22.6,29.7,29.8,31.6,32.2,32.3,113.5,122.1$, 125.3, 125.4, 129.5, 130.7, 131.8, 132.5, 139.0, 139.6; IR (KBr) 2926, 2856, 1470, 1030, $708 \mathrm{~cm}^{-1}$, Anal. Calcd. for $\mathrm{C}_{22} \mathrm{H}_{29} \mathrm{BrS}_{2}$ : C, 60.40; H, 6.68, Found: C, 60.22; H, 6.91.

2,7-Dibromo-4,5-dihexylbenzo[1,2-b:4,3-b']dithiophene (17). To a stirred solution of 15 (2.00 g, $5.58 \mathrm{mmol})$ in $\mathrm{CH}_{2} \mathrm{Cl}_{2}(35 \mathrm{~mL})$ was added NBS $(2.18 \mathrm{~g}, 12.2 \mathrm{mmol})$ under argon and the mixture was stirred at room temperature for $3 \mathrm{~h}$. After aqueous $\mathrm{Na}_{2} \mathrm{~S}_{2} \mathrm{O}_{3}$ was added, the organic layer was separated. The aqueous layer was extracted with ethyl acetate. The combined organic phases were washed with brine, dried over $\mathrm{Na}_{2} \mathrm{SO}_{4}$ and concentrated. The crude product was purified by silica gel column chromatography (hexane) to give $17(2.85 \mathrm{~g}, 99 \%)$ as a light yellow solid. $\mathrm{mp} 40-44{ }^{\circ} \mathrm{C} ;{ }^{1} \mathrm{H} \mathrm{NMR}$ $\left(\mathrm{CDCl}_{3}\right) \delta 0.92(\mathrm{t}, J=6.9 \mathrm{~Hz}, 6 \mathrm{H}), 1.27-1.56(\mathrm{~m}, 12 \mathrm{H}), 1.60-1.77(\mathrm{~m}, 4 \mathrm{H}), 2.84(\mathrm{t}, J=8.1 \mathrm{~Hz}, 4 \mathrm{H}), 7.53$ $(\mathrm{s}, 2 \mathrm{H}) ;{ }^{13} \mathrm{C} \mathrm{NMR}\left(\mathrm{CDCl}_{3}\right) \delta 14.1,22.6,29.6,29.8,31.6,32.2,114.0,125.0,129.9,131.6,140.0 ;$ IR (KBr) 2928, 2857, 1470, 1104, $725 \mathrm{~cm}^{-1}$, Anal. Calcd. for $\mathrm{C}_{22} \mathrm{H}_{28} \mathrm{Br}_{2} \mathrm{~S}_{2}: \mathrm{C}, 51.17$; H, 5.47. Found: C, $51.17 ; \mathrm{H}, 5.48$

\section{2-(4,4,5,5-Tetramethyl-1,3,2-dioxaborolane-2-yl)-4,5-dihexylbenzo[1,2-b:4,3-b']dithiophene (18).}

To a stirred solution of $15(1.00 \mathrm{~g}, 2.79 \mathrm{mmol})$ in THF (30 mL) were added $N, N, N^{\prime}, N^{\prime}-$ tetramethylethylenediamine (TMEDA) $(0.42 \mathrm{~mL}, 2.80 \mathrm{mmol})$ and $n$-BuLi $(3.1 \mathrm{mmol}, 2.3 \mathrm{~mL}$ of $1.35 \mathrm{M}$ 
solution in hexane) at $-78{ }^{\circ} \mathrm{C}$ under argon and the mixture was stirred for $2 \mathrm{~h}$. To the resulting yellow solution was added a solution of 2-isopropoxy-4,4,5,5-tetramethyl-1,3,2-dioxaborolane (1.20 mL, 6.98 mmol) in THF $(6 \mathrm{~mL})$ at $-78{ }^{\circ} \mathrm{C}$. The reaction mixture was allowed to warm to room temperature during $5 \mathrm{~h}$. The reaction was quenched by saturated aqueous ammonium chloride. The organic layer was separated and the aqueous layer was extracted with ethyl acetate. The combined organic phases were washed with brine, dried over $\mathrm{Na}_{2} \mathrm{SO}_{4}$ and concentrated. The crude product was purified by silica gel column chromatography (10 : 1, hexane-ethyl acetate) to give $\mathbf{1 8}(1.09 \mathrm{~g}, 80 \%)$ as a green solid. $\mathrm{mp}$ 89-90 ${ }^{\circ} \mathrm{C} ;{ }^{1} \mathrm{H}$ NMR $\left(\mathrm{CDCl}_{3}\right) \delta 0.91(\mathrm{t}, J=6.9 \mathrm{~Hz}, 6 \mathrm{H}), 1.32-1.40(\mathrm{~m}, 12 \mathrm{H}), 1.41(\mathrm{~s}, 12 \mathrm{H}), 1.69-1.80(\mathrm{~m}$, 4H), 2.96-3.03 (m, 4H), $7.47(\mathrm{~d}, J=5.4 \mathrm{~Hz}, 1 \mathrm{H}), 7.69(\mathrm{~d}, J=5.4 \mathrm{~Hz}, 1 \mathrm{H}), 8.23(\mathrm{~s}, 1 \mathrm{H}) ;{ }^{13} \mathrm{C} \mathrm{NMR}$ $\left(\mathrm{CDCl}_{3}\right) \delta 14.1,22.6,22.7,24.8,29.7,29.8,29.9,31.6,31.7,32.3,84.4,122.5,125.2,130.3,131.6$, 132.7, 133.1, 133.7, 138.7, 143.3; IR (KBr) 2954, 2928, 1511, 1341, $711 \mathrm{~cm}^{-1}$, Anal. Calcd. for $\mathrm{C}_{24} \mathrm{H}_{41} \mathrm{BO}_{2} \mathrm{~S}_{2} \mathrm{C}, 69.40 ; \mathrm{H}, 8.53$, found: $\mathrm{C}, 69.24 ; \mathrm{H}, 8.74$.

2-Tributyltin(IV)-4,5-dihexylbenzo[1,2-b:4,3-b']dithiophene (19). To a stirred solution of 15 (0.40 $\mathrm{g}, 1.12 \mathrm{mmol})$ in THF ( $3 \mathrm{~mL})$ were added $n$-BuLi $(1.2 \mathrm{mmol}, 0.8 \mathrm{~mL}$ of $1.56 \mathrm{M}$ solution in hexane) at $78{ }^{\circ} \mathrm{C}$ under argon and the mixture was stirred for $2 \mathrm{~h}$. To the resulting yellow solution was added tributyltin(IV) chloride $(0.33 \mathrm{~mL}, 1.2 \mathrm{mmol})$ at $-78^{\circ} \mathrm{C}$. The reaction mixture was stirred for $2 \mathrm{~h}$ at -78 ${ }^{\circ} \mathrm{C}$. The mixture was filtrated through silica gel to remove inorganic salt. The silica gel was washed with ethyl acetate and the filtrate was concentrated, to give 19 (0.78 g, qnantitative) as colorless oil. This compound was used for the following reaction without further purification.

2,7-Bis[(tributyltin(IV)]-4,5-dihexylbenzo[1,2-b:4,3-b’ $]$ dithiophene (20). To a stirred solution of 15 $(0.50 \mathrm{~g}, 1.4 \mathrm{mmol})$ in THF ( $8 \mathrm{ml})$ was added and $n$-BuLi ( $3.1 \mathrm{mmol}, 2.1 \mathrm{ml}$ of $1.45 \mathrm{M}$ hexane solution) at $0{ }^{\circ} \mathrm{C}$ and the mixture was stirred for $1.5 \mathrm{~h}$ at $0{ }^{\circ} \mathrm{C}$. To the resulting yellow solution was added tributyltin (IV) chloride $(0.91 \mathrm{ml}, 3.5 \mathrm{mmol})$ at $0{ }^{\circ} \mathrm{C}$. The reaction mixture was stirred for $3 \mathrm{~h}$. The mixture was filtrated through celite pad and the filtrate was concentrated. The residue was dried in 
vacuo to give 20 (crude) as light yellw oil. This compound was used for the following reaction without further purification.

2,2'-Bi(7-bromo-4,5-dihexylbenzo[1,2-b:4,3- $\left.b^{\prime}\right]$ dithiophene) (21). To a stirred solution of compound $17(1.97 \mathrm{~g}, 3.81 \mathrm{mmol})$ in THF $(15 \mathrm{~mL})$ were added $n$-BuLi $(3.8 \mathrm{mmol}, 2.6 \mathrm{~mL}$ of $1.49 \mathrm{M}$ solution in hexane) at $-78{ }^{\circ} \mathrm{C}$ under argon and the mixture was stirred for $2 \mathrm{~h}$. To the resulting yellow solution was added dropwise Iron(III) acetylacetonate $(1.34 \mathrm{~g}, 3.81 \mathrm{mmol})$ in $\mathrm{THF}(15 \mathrm{~mL})$ at $-78^{\circ} \mathrm{C}$. The reaction mixture was allowed to warm to room temperature and stirred over night. The red suspension was poured onto $20 \mathrm{~mL}$ of diethyl ether, and $5 \mathrm{~mL}$ of concentrated hydrochloric acid was added, and filtrated. The residue was purified by silica gel column chromatography (chloroform) to give 21 (0.62 g, 37\%) as a yellow solid. $\mathrm{mp} 227-230{ }^{\circ} \mathrm{C} ;{ }^{1} \mathrm{H} \mathrm{NMR}\left(\mathrm{CDCl}_{3}\right) \delta 0.90-0.96(\mathrm{~m}, 12 \mathrm{H}), 1.35-$ $1.42(\mathrm{~m}, 16 \mathrm{H}), 1.46-1.53(\mathrm{~m}, 8 \mathrm{H}), 1.66-1.76(\mathrm{~m}, 8 \mathrm{H}), 2.86-2.97(\mathrm{~m}, 8 \mathrm{H}), 7.68(\mathrm{~s}, 2 \mathrm{H}), 7.76(\mathrm{~s}, 2 \mathrm{H}) ;{ }^{13} \mathrm{C}$ $\operatorname{NMR}\left(\mathrm{CDCl}_{3}\right) \delta 14.1,22.6,29.8,29.9,31.7,32.4,113.9,119.3,125.4,130.4,130.5,132.5,136.6,138.5$ 140.2; IR (KBr) 2955, 2926, 2857, 2359, 1470, $812 \mathrm{~cm}^{-1}$; Anal. Calcd. for $\mathrm{C}_{44} \mathrm{H}_{56} \mathrm{Br}_{2} \mathrm{~S}_{4} \mathrm{C}, 60.54 ; \mathrm{H}$, 6.47. found: C, $60.25 ; \mathrm{H}, 6.40$.

7-Bromo-2,2'-bi(4,5-dihexylbenzo[1,2-b:4,3-b']dithiophene) (22). To a stirred solution of 17 (0.11 g, $0.21 \mathrm{mmol})$ and $18(0.10 \mathrm{~g}, 0.21 \mathrm{mmol})$ in toluene $(4 \mathrm{~mL})$ was added $\mathrm{Pd}\left(\mathrm{PPh}_{3}\right)_{4}(14 \mathrm{mg}, 0.012 \mathrm{mmol})$ and $2 \mathrm{M}$ aqueous $\mathrm{Na}_{2} \mathrm{CO}_{3}(2 \mathrm{~mL})$ under argon, and the mixture was refluxed for $24 \mathrm{~h}$. Water was added to mixture, and the mixture was diluted with chloroform. The organic layer was separated and the aqueous layer was extracted with chloroform. The combined organic phases were washed with brine, dried over $\mathrm{Na}_{2} \mathrm{SO}_{4}$ and concentrated. The crude product was washed by ethanol, dried in vacuo, and the residue was purified by gel permeation chromatography (chloroform) to give 22 (65 $\mathrm{mg}, 40 \%$ ) as a yellow solid. mp 187-189 ${ }^{\circ} \mathrm{C} ;{ }^{1} \mathrm{H}$ NMR $\left(\mathrm{CDCl}_{3}\right) \delta .0 .90-0.96(\mathrm{~m}, 12 \mathrm{H}), 1.35-1.43(\mathrm{~m}, 16 \mathrm{H}), 1.47-1.58$ (m, 8H), 1.69-1.81 (m, 8H), 2.86-2.92 (m, 4H), 2.96-3.02 (m, 4H), $7.50(\mathrm{~d}, J=5.5 \mathrm{~Hz}, 1 \mathrm{H}), 7.68(\mathrm{~s}, 1 \mathrm{H})$, $7.69(\mathrm{~d}, J=5.5 \mathrm{~Hz}, 1 \mathrm{H}), 7.77(\mathrm{~s}, 1 \mathrm{H}), 7.87(\mathrm{~s}, 1 \mathrm{H}) ;{ }^{13} \mathrm{C} \mathrm{NMR}\left(\mathrm{CDCl}_{3}\right) \delta 14.1,22.6,22.7,29.7,29.8$ $29.9,31.6,32.4,113.8,119.1,119.7,122.4,125.3,125.4,130.0,130.2,130.5,131.2,132.4,132.5$ 
132.7, 133.4, 136.0, 136.8, 138.2, 138.4, 139.1, 140.1; IR (KBr) 2955, 2925, 2856, 1468, 819, $\mathrm{cm}^{-1}$; Anal. Calcd for $\mathrm{C}_{44} \mathrm{H}_{57} \mathrm{BrS}_{4}$ : C, 66.55; H, 7.24\%. Found: C, 66.45; H, 7.12\%.

2,7-Diiodo-4,5-dihexylbenzo[1,2-b:4,3-b']dithiophene (23). To a stirred solution of 15 (3.00 g, 8.37 $\mathrm{mmol})$ in THF $(40 \mathrm{~mL})$ was added $n$-BuLi $(25.1 \mathrm{mmol}, 16.8 \mathrm{~mL}$ of $1.50 \mathrm{M}$ solution in hexane $)$ at $-78^{\circ} \mathrm{C}$ and the mixture was stirred for $2 \mathrm{~h}$. To the resulting yellow solution was added a solution of iodine $(6.37 \mathrm{~g}, 25.1 \mathrm{mmol})$ in $\mathrm{THF}(10 \mathrm{~mL})$ at $-78^{\circ} \mathrm{C}$. The reaction mixture was allowed to warm to room temperature and stirred for $2.5 \mathrm{~h}$. The reaction was quenched by aqueous $\mathrm{Na}_{2} \mathrm{~S}_{2} \mathrm{O}_{3}$. The organic layer was separated and the aqueous layer was extracted with ethyl acetate. The organic extracts were washed with brine, dried over $\mathrm{Na}_{2} \mathrm{SO}_{4}$ and concentrated. The residue was chromatographed on silica gel using hexane as an eluent to give 23 as a white crystal $(4.35 \mathrm{~g}, 85 \%)$. mp 96-98 ${ }^{\circ} \mathrm{C}$; ${ }^{1} \mathrm{H}$ NMR $\left(\mathrm{CDCl}_{3}\right) \delta 0.91(\mathrm{t}, J=6.9 \mathrm{~Hz}, 6 \mathrm{H}), 1.32-1.37(\mathrm{~m}, 8 \mathrm{H}), 1.44-1.47(\mathrm{~m}, 4 \mathrm{H}), 1.63-1.73(\mathrm{~m}, 4 \mathrm{H}), 2.86(\mathrm{t}, J=$ 8.1 Hz, 4H), $7.77(\mathrm{~s}, 2 \mathrm{H}) ;{ }^{13} \mathrm{C} \mathrm{NMR}\left(\mathrm{CDCl}_{3}\right) \delta 14.1,22.6,29.6,29.8,31.6,32.2,129.7,132.2,132.4$, 143.5; IR (KBr) 2956, 2928, 2856, 1470, 1363, 1201, $1103 \mathrm{~cm}^{-1}$; Anal. Calcd for $\mathrm{C}_{22} \mathrm{H}_{28} \mathrm{I}_{2} \mathrm{~S}_{2}$ : C, 43.29; H, 4.62. Found: C, 43.00; H, 4.33.

4,5-Dihexylbenzo[1,2-b:4,3- $\left.b^{\prime}\right]$ dithiophene-2-carboxaldehyde (24). To a stirred solution of 15 (5.00 g, $13.9 \mathrm{mmol})$ in THF $(110 \mathrm{~mL})$ were added $N, N, N^{\prime}, N^{\prime}$-tetramethylethylenediamine (TMEDA) (3.16 $\mathrm{mL}, 20.5 \mathrm{mmol}$ ) and $n$-BuLi (14.6 mmol, $10.5 \mathrm{~mL}$ of $1.39 \mathrm{M}$ solution in hexane) at $-78{ }^{\circ} \mathrm{C}$, and the mixture was stirred for $1.5 \mathrm{~h}$. To the resulting yellow solution was added DMF $(0.39 \mathrm{~mL}, 5.07 \mathrm{mmol})$ at $-78{ }^{\circ} \mathrm{C}$. The reaction mixture was allowed to warm to room temperature for $2 \mathrm{~h}$. The reaction was quenched by saturated aqueous ammonium chloride and 10\% hydrochloric acid. The organic layer was separated and the aqueous layer was extracted with ethyl acetate. The combined organic phases were washed with brine, dried over $\mathrm{Na}_{2} \mathrm{SO}_{4}$, and concentrated. The crude product was purified by silica gel column chromatography (10:1, hexane-ethyl acetate) to give 24 (4.56 g, 85\%) as a light red solid. mp $49-50{ }^{\circ} \mathrm{C} ;{ }^{1} \mathrm{H}$ NMR $\left(\mathrm{CDCl}_{3}\right) \oint 0.92(\mathrm{t}, J=6.9 \mathrm{~Hz}, 6 \mathrm{H}), 1.34-1.40(\mathrm{~m}, 8 \mathrm{H}), 1.45-1.55(\mathrm{~m}, 4 \mathrm{H}), 1.68-1.80$ (m, 4H), 2.95-3.03 (m, 4H), $7.58(\mathrm{~d}, J=5.7 \mathrm{~Hz}, 1 \mathrm{H}), 7.72(\mathrm{~d}, J=5.7 \mathrm{~Hz}, 1 \mathrm{H}), 8.34(\mathrm{~s}, 1 \mathrm{H}), 10.12(\mathrm{~s}$ 
$1 \mathrm{H}) ;{ }^{13} \mathrm{C} \mathrm{NMR}\left(\mathrm{CDCl}_{3}\right) \delta 14.0,22.5,22.6,29.5,29.6,29.8,31.5,31.6,32.0,32.6,122.1,126.6,130.4$,

131.9, 132.4, 134.0, 141.4, 142.9, 184.2; IR (KBr) 2926, 2856, 1664, 1471, $714 \mathrm{~cm}^{-1}$; Anal. Calcd for $\mathrm{C}_{23} \mathrm{H}_{30} \mathrm{OS}_{2}: \mathrm{C}, 71.45 ; \mathrm{H}, 7.82$. Found: C, 71.30; H, 7.57.

4,5-Dihexylbenzo[1,2-b:4,3- $\left.b^{\prime}\right]$ dithiophene-2-methanol (25). To a stirred solution of aldehyde 24 $(3.55 \mathrm{~g}, 9.18 \mathrm{mmol})$ in THF $(12 \mathrm{~mL})$ and ethanol $(15 \mathrm{~mL})$ was added sodium borohydride $(0.52 \mathrm{~g}, 13.8$ mmol) at $0{ }^{\circ} \mathrm{C}$ and the resulting yellow suspension was stirred for $2 \mathrm{~h}$ at room temperature. The reaction was quenched by aqueous citric acid and the mixture was diluted with ethyl acetate, and the separated aqueous layer was extracted with ethyl acetate. The combined organic extracts were washed with brine, dried over $\mathrm{Na}_{2} \mathrm{SO}_{4}$ and concentrated. The residue was purified by silica gel column chromatography (3 : 1, hexane-ethyl acetate) to give $25(3.50 \mathrm{~g}, 99 \%)$ as a white solid. mp 67-68 ${ }^{\circ} \mathrm{C} ;{ }^{1} \mathrm{H}$ NMR $\left(\mathrm{CDCl}_{3}\right)$ $\delta 0.92(\mathrm{t}, J=6.9 \mathrm{~Hz}, 6 \mathrm{H}), 1.34-1.40(\mathrm{~m}, 8 \mathrm{H}), 1.45-1.55(\mathrm{~m}, 4 \mathrm{H}), 1.68-1.78(\mathrm{~m}, 4 \mathrm{H}), 1.89(\mathrm{t}, J=6.1 \mathrm{~Hz}$, 1H), 2.92-3.00 (m, 4H), $4.99(\mathrm{dd}, J=1.2,6.1 \mathrm{~Hz}, 2 \mathrm{H}), 7.46(\mathrm{~d}, J=5.5 \mathrm{~Hz}, 1 \mathrm{H}), 7.57$ (s, 1H), $7.62(\mathrm{~d}, J$ $=5.5 \mathrm{~Hz}, 1 \mathrm{H}) ;{ }^{13} \mathrm{C} \mathrm{NMR}\left(\mathrm{CDCl}_{3}\right) \delta 14.1,22.6,29.7,29.8,31.6,32.1,32.3,60.9,120.3,122.3,125.0$, 130.3, 130.4, 132.4, 132.6, 138.7, 138.8, 143.2; IR (KBr) 3337, 2923, 2856, 1470, $717 \mathrm{~cm}^{-1}$; Anal. Calcd for $\mathrm{C}_{23} \mathrm{H}_{32} \mathrm{OS}_{2}$ : C, 71.08; H, 8.30. Found: C, 71.08; H, 8.47.

\section{(\{4,5-Dihexylbenzo[1,2-b:4,3-b’]dithiophene-2-yl\}methyl)triphenylphosphonium bromide (26).}

To a stirred solution of alcohol 25 (1.38 g, $3.55 \mathrm{mmol})$ in acetonitrile $(30 \mathrm{~mL})$ was added triphenylphosphine hydrobromide $(1.46 \mathrm{~g}, 4.26 \mathrm{mmol})$ at room temperature, and the mixture was heated under reflux for $3 \mathrm{~h}$. The solvent was evaporated and the residue was washed with ether. The obtained powder was dried in vacuo to give 26 (2.53 g, 98\%) and was used without further purification. ${ }^{1} \mathrm{H}$ $\operatorname{NMR}\left(\mathrm{CDCl}_{3}\right) \oint 0.95(\mathrm{~m}, 6 \mathrm{H}), 1.23-1.75(\mathrm{~m}, 16 \mathrm{H}), 2.80-2.98(\mathrm{~m}, 4 \mathrm{H}), 7.41(\mathrm{~d}, J=5.4 \mathrm{~Hz}, 1 \mathrm{H}), 7.53(\mathrm{~d}$, $J=5.4 \mathrm{~Hz}, 1 \mathrm{H}), 7.58-7.70(\mathrm{~m}, 6 \mathrm{H}), 7.72-7.88(\mathrm{~m}, 9 \mathrm{H}), 7.89(\mathrm{~s}, 1 \mathrm{H})$.

4,5-Dihexylbenzo[1,2-b:4,3- $\left.b^{\prime}\right]$ dithiophene-2,7-dicarboxaldehyde (27). To a stirred solution of 15 $(1.0 \mathrm{~g}, 2.8 \mathrm{mmol})$ in THF $(40 \mathrm{~mL})$ were successively added $N, N, N^{\prime}, N^{\prime}$-tetramethylethylenediamine (TMEDA) $(1.3 \mathrm{~mL}, 8.4 \mathrm{mmol})$ and $n$-BuLi $\left(8.4 \mathrm{mmol}, 5.6 \mathrm{~mL}\right.$ of $1.5 \mathrm{M}$ solution in hexane) at $-78{ }^{\circ} \mathrm{C}$ 
and this mixture was stirred for $2 \mathrm{~h}$. To the resulting yellow solution was added DMF (2.3 mL, 27.9 mmol) at $-78{ }^{\circ} \mathrm{C}$. The reaction mixture was allowed to warm to room temperature and stirred for $3 \mathrm{~h}$. The reaction was quenched by saturated aqueous ammonium chloride. The organic layer was separated and the aqueous layer was extracted with ethyl acetate. The combined organic phases were washed with brine, dried over $\mathrm{Na}_{2} \mathrm{SO}_{4}$, and concentrated. The crude product was purified by silica gel column chromatography (3:1, hexane-ethyl acetate) to give $27(1.01 \mathrm{~g}, 87 \%)$ as a yellow solid. mp 118-120 ${ }^{\circ} \mathrm{C} ;{ }^{1} \mathrm{H}$ NMR $\left(\mathrm{CDCl}_{3}\right) \delta$ 0.90-0.94 (m, 6H), 1.35-1.43 (m, 8H), 1.52-1.55 (m, 4H), 1.69-1.79 (m, 4H), $3.01(\mathrm{t}, J=8.1 \mathrm{~Hz}, 4 \mathrm{H}), 8.37(\mathrm{~s}, 2 \mathrm{H}), 10.15(\mathrm{~s}, 2 \mathrm{H}) ;{ }^{13} \mathrm{C} \mathrm{NMR}\left(\mathrm{CDCl}_{3}\right) \delta 14.1,22.6,29.6,29.8,31.5$, 32.4, 131.4, 133.2, 135.1, 142.8, 143.8, 184.2; IR(KBr) 2956, 2927, 2857, 1674, 1664, 1499, 1225, 1155, $1103 \mathrm{~cm}^{-1}$; Anal. Calcd. for $\mathrm{C}_{24} \mathrm{H}_{30} \mathrm{O}_{2} \mathrm{~S}_{2}:$ C, 69.52; H, 7.29. Found: C, 69.59; H, 7.39.

\section{2-(Triisopropylsiloxylmethyl)-4,5-dihexylbenzo[1,2-b:4,3-b']dithiophene (28).To a stirred solution} of a mixture of 25 (3.37 g, $8.67 \mathrm{mmol})$ and imidazole (1.48 g, $21.7 \mathrm{mmol})$ in DMF (15 mL) was added triisopropylsilyl chloride (TIPSCl) $(2.23 \mathrm{~mL}, 10.4 \mathrm{mmol})$ at room temperature. After stirring for $2 \mathrm{~h}$, the yellow reaction mixture was quenched with $10 \%$ hydrochloric acid. The organic layer was separated and the aqueous layer was extracted with ethyl acetate. The organic extracts were washed with brine, dried over $\mathrm{Na}_{2} \mathrm{SO}_{4}$ and concentrated. The residue was purified by silica gel column chromatography (20 : 1, hexane-ethyl acetate) to give 28 (4.57 g, 97\%) as light yellow oil. ${ }^{1} \mathrm{H}$ NMR $\left(\mathrm{CDCl}_{3}\right) \delta 0.91(\mathrm{~m}, 6 \mathrm{H}), 1.12(\mathrm{~d}, J=6.0 \mathrm{~Hz}, 18 \mathrm{H}), 1.15-1.25(\mathrm{~m}, 3 \mathrm{H}), 1.33-1.38(\mathrm{~m}, 8 \mathrm{H}), 1.45-1.52(\mathrm{~m}$, 4H), 1.68-1.78 (m, 4H), 2.92-2.98 (m, 4H), $5.10(\mathrm{~s}, 2 \mathrm{H}), 7.42(\mathrm{~d}, J=5.4 \mathrm{~Hz}, 1 \mathrm{H}), 7.48(\mathrm{~s}, 1 \mathrm{H}), 7.60(\mathrm{~d}$, $J=5.4 \mathrm{~Hz}, 1 \mathrm{H}) ;{ }^{13} \mathrm{C} \mathrm{NMR}\left(\mathrm{CDCl}_{3}\right) . \delta 12.1,14.1,18.0,22.6,29.8,31.6,32.1,32.3,61.9,118.3,122.4$, 124.7, 129.8, 130.4, 132.5, 132.6, 138.2, 138.5, 145.1; IR (Si) 2928, 2864, 1465, 1150, 883, $667 \mathrm{~cm}^{-1}$; Anal. Calcd for $\mathrm{C}_{32} \mathrm{H}_{52} \mathrm{OS}_{2} \mathrm{Si}$ : C, 70.53; H, 9.62. Found: C, 70.54; H, 9.42.

\section{2-(Triisopropylsiloxylmethyl)-4,5-dihexylbenzo[1,2-b:4,3-b']dithiophene-7-carboxaldehyde (29).}

To a stirred solution of compound 28 (4.5 g, $8.3 \mathrm{mmol})$ in THF $(25 \mathrm{~mL})$ were successively added $N, N, N^{\prime}, N^{\prime}$-tetramethylethylenediamine (TMEDA) $(1.9 \mathrm{~mL}, 12 \mathrm{mmol})$ and $n$-BuLi $(9.9 \mathrm{mmol}, 6.6 \mathrm{~mL}$ of 
1.5 $\mathrm{M}$ solution in hexane) at $-78^{\circ} \mathrm{C}$, and the mixture was stirred for $1.5 \mathrm{~h}$. To the resulting dark purple solution was added DMF $(2.6 \mathrm{~mL}, 33 \mathrm{mmol})$ at $-78{ }^{\circ} \mathrm{C}$. The reaction mixture was allowed to warm to room temperature during $2 \mathrm{~h}$. The reaction was quenched by saturated aqueous ammonium chloride and $10 \%$ hydrochloric acid. The organic layer was separated and the aqueous layer was extracted with ethyl acetate. The combined organic phases were washed with brine, dried over $\mathrm{Na}_{2} \mathrm{SO}_{4}$, and concentrated. The crude product was purified by silica gel column chromatography (15:1, hexane-ethyl acetate) to give $29(4.6 \mathrm{~g}, 97 \%)$ as yellow oil. ${ }^{1} \mathrm{H} \mathrm{NMR}\left(\mathrm{CDCl}_{3}\right) \delta 0.91(\mathrm{~m}, 6 \mathrm{H}), 1.13(\mathrm{~d}, J=6.0 \mathrm{~Hz}, 18 \mathrm{H}), 1.17-$ $1.28(\mathrm{~m}, 3 \mathrm{H}), 1.34-1.39(\mathrm{~m}, 8 \mathrm{H}), 1.45-1.52(\mathrm{~m}, 4 \mathrm{H}), 1.66-1.79(\mathrm{~m}, 4 \mathrm{H}), 2.93-3.00(\mathrm{~m}, 4 \mathrm{H}), 5.13(\mathrm{~d}, J=$ $0.9 \mathrm{~Hz}, 2 \mathrm{H}), 7.53$ (t, $J=0.9 \mathrm{~Hz}, 1 \mathrm{H}), 8.28$ (s, 1H), 10.12 (s, 1H); IR (Si) 2929, 2865, 1674, 1459, 1158, 883, $667 \mathrm{~cm}^{-1}$; Anal. Calcd for $\mathrm{C}_{33} \mathrm{H}_{52} \mathrm{O}_{2} \mathrm{~S}_{2} \mathrm{Si}: \mathrm{C}, 69.17 ; \mathrm{H}, 9.15$. Found: C, 69.04; H, 9.07.

\section{2-(Triisopropylsiloxylmethyl)-7-(\{4,5-dihexylbenzo[1,2-b:4,3-b’]dithiophene-2-yl\}ethenyl)-4,5-}

dihexylbenzo[1,2-b:4,3-b']dithiophene (30). Aldehyde 29 (0.10 g, $0.25 \mathrm{mmol})$ and phosphonium salt $26(0.21 \mathrm{~g}, 0.25 \mathrm{mmol})$ were dissolved in a mixture of THF $(2 \mathrm{~mL})$ and ethanol $(4 \mathrm{~mL})$. To the resulting solution was added potassium tert-butoxide $(t-\mathrm{BuOK})(0.06 \mathrm{~g}, 0.50 \mathrm{mmol})$ at room temperature, and the yellowish orange suspension was stirred for $5 \mathrm{~h}$. The reaction was quenched by water, and the precipitate was dissolved with chloroform, and the separated aqueous layer was extracted with chloroform. The combined organic extracts were washed with brine, dried over $\mathrm{Na}_{2} \mathrm{SO}_{4}$ and concentrated. The residue was purified by silica gel column chromatography $(50: 1$, hexane-ethyl acetate) and the solvent was removed. The resulting yellowish orange solid was washed with ethanol and dried in vacuo to give $30(0.23 \mathrm{~g}, 74 \%)$ as a yellow solid. $\mathrm{mp} 115-116{ }^{\circ} \mathrm{C} ;{ }^{1} \mathrm{H} \mathrm{NMR}\left(\mathrm{CDCl}_{3}\right) \delta 0.92$ $(\mathrm{t}, J=6.6 \mathrm{~Hz}, 6 \mathrm{H}), 0.94(\mathrm{t}, J=6.6 \mathrm{~Hz}, 6 \mathrm{H}), 1.13(\mathrm{~d}, J=6.0 \mathrm{~Hz}, 18 \mathrm{H}), 1.17-1.28(\mathrm{~m}, 3 \mathrm{H}), 1.35-1.41(\mathrm{~m}$, $16 \mathrm{H}), 1.47-1.56(\mathrm{~m}, 8 \mathrm{H}), 1.69-1.77(\mathrm{~m}, 8 \mathrm{H}), 2.91-3.00(\mathrm{~m}, 8 \mathrm{H}), 5.11(\mathrm{~d}, J=0.9 \mathrm{~Hz}, 2 \mathrm{H}), 7.30(\mathrm{~s}, 2 \mathrm{H})$, $7.44(\mathrm{~s}, 1 \mathrm{H}), 7.47(\mathrm{~d}, J=5.4 \mathrm{~Hz}, 1 \mathrm{H}), 7.55(\mathrm{~s}, 1 \mathrm{H}), 7.60(\mathrm{~s}, 1 \mathrm{H}), 7.62(\mathrm{~d}, J=5.4 \mathrm{~Hz}, 1 \mathrm{H})$; IR $(\mathrm{KBr})$ 2952, 2926, 2856, 1460, 1089, 935, 882, $823 \mathrm{~cm}^{-1}$; Anal. Calcd for $\mathrm{C}_{56} \mathrm{H}_{82} \mathrm{OS}_{4} \mathrm{Si}: \mathrm{C}, 72.51 ; \mathrm{H}, 8.91$. Found: C, 72.50; H, 9.17. 


\section{2-(Hydroxymethyl)-7-(\{4,5-dihexylbenzo[1,2-b:4,3-b’]dithiophene-2-yl\}ethenyl)-4,5-}

dihexylbenzo[1,2-b:4,3- $\boldsymbol{b}^{\prime}$ ]dithiophene (31). To a stirred solution of 30 (0.79 g, $\left.0.85 \mathrm{mmol}\right)$ in THF (7 $\mathrm{mL}$ ) was added tetra-n-butylammonium fluoride (TBAF) (1.3 mmol, $1.3 \mathrm{~mL}$ of $1 \mathrm{M}$ solution in THF) at room temperature and the resulting dark brown solution was stirred for $2 \mathrm{~h}$ at room temperature. The reaction was quenched by water and the mixture was diluted with chloroform, and the separated aqueous layer was extracted with chloroform. The combined organic extracts were washed with brine, and dried over $\mathrm{Na}_{2} \mathrm{SO}_{4}$ and concentrated. The residue was washed with hexane and dried in vacuo to give $31(0.53 \mathrm{~g}, 81 \%)$ as a brown solid. $\mathrm{mp} 201-202{ }^{\circ} \mathrm{C} ;{ }^{1} \mathrm{H} \mathrm{NMR}\left(\mathrm{CDCl}_{3}\right) \delta 0.92(\mathrm{t}, J=6.6 \mathrm{~Hz}, 6 \mathrm{H})$, $0.94(\mathrm{t}, J=6.6 \mathrm{~Hz}, 6 \mathrm{H}), 1.34-1.42(\mathrm{~m}, 16 \mathrm{H}), 1.48-1.55(\mathrm{~m}, 8 \mathrm{H}), 1.70-1.78(\mathrm{~m}, 8 \mathrm{H}), 1.92(\mathrm{t}, J=6.3 \mathrm{~Hz}$, 1H), 2.92-3.00 (m, 8H), $4.99(\mathrm{~d}, J=6.3 \mathrm{~Hz}, 2 \mathrm{H}), 7.29(\mathrm{~s}, 2 \mathrm{H}), 7.47(\mathrm{~d}, J=5.4 \mathrm{~Hz}, 1 \mathrm{H}), 7.51(\mathrm{~s}, 1 \mathrm{H})$, $7.54(\mathrm{~s}, 1 \mathrm{H}), 7.61(\mathrm{~s}, 1 \mathrm{H}), 7.62(\mathrm{t}, J=5.4 \mathrm{~Hz}, 1 \mathrm{H}) ;{ }^{13} \mathrm{C} \mathrm{NMR}\left(\mathrm{CDCl}_{3}\right) \delta$ 14.1, 22.6, 29.8, 31.6, 32.3, 61.0, $120.2,122.0,122.3,122.4,123.6,123.8,125.2,130.1,130.3,131.3,132.3,132.5,133.2,137.9,139.0$, 141.0, 141.2, 143.6; IR (KBr) 3333, 2955, 2926, 2857, 1466, 931, $828 \mathrm{~cm}^{-1}$; Anal. Calcd for $\mathrm{C}_{47} \mathrm{H}_{62} \mathrm{OS}_{4}$ : C, 73.19; H, 8.10. Found: C, 73.09; H, 7.92.

\section{7-(\{4,5-dihexylbenzo[1,2-b:4,3-b’]dithiophene-2-yl\}ethenyl)-4,5-Dihexyl-benzo[1,2-b:4,3-}

$\boldsymbol{b}^{\prime}$ ]dithiophene-2-carboxaldehyde (32). To a stirred solution of alcohol 31 (85 $\left.\mathrm{mg}, 0.11 \mathrm{mmol}\right)$ in DMF (3 mL) was added pyridinium dichromate (PDC) $(62 \mathrm{mg}, 0.17 \mathrm{mmol})$ at room temperature and the resulting dark brown solution was stirred for $2.5 \mathrm{~h}$ at room temperature. The reaction was quenched by $10 \%$ hydrochloric acid the mixture was diluted with chloroform, and the separated aqueous layer was extracted with chloroform. The combined organic extracts were washed with aqueous $\mathrm{NaHCO}_{3}$ and brine, and dried over $\mathrm{Na}_{2} \mathrm{SO}_{4}$ and concentrated. The residue was purified by silica gel column chromatography (2: 1, chloroform-hexane) to give 32 (50 mg, 59\%) as a red brown solid. mp 169-170 ${ }^{\circ} \mathrm{C} ;{ }^{1} \mathrm{H}$ NMR $\left(\mathrm{CDCl}_{3}\right) \delta$ 0.90-0.97 (m, 12H), 1.34-1.44 (m, 16H), 1.48-1.60 (m, 8H), 1.69-1.80 (m, 8H), 2.90-2.98 (m, 8H), 7.22 (d, $J=15.6 \mathrm{~Hz}, 1 \mathrm{H}), 7.30(\mathrm{~d}, J=15.6 \mathrm{~Hz}, 1 \mathrm{H}), 7.45(\mathrm{~d}, J=5.5 \mathrm{~Hz}, 1 \mathrm{H}), 7.53(\mathrm{~s}$, 1H), $7.56(\mathrm{~s}, 1 \mathrm{H}), 7.57(\mathrm{~d}, J=5.5 \mathrm{~Hz}, 1 \mathrm{H}), 8.16(\mathrm{~s}, 1 \mathrm{H}), 10.05(\mathrm{~s}, 1 \mathrm{H}) ;{ }^{13} \mathrm{C} \mathrm{NMR}\left(\mathrm{CDCl}_{3}\right) \delta 14.1,22.6$, 
$29.8,29.9,31.6,32.3,121.4,122.3,122.7,123.0,124.7,125.3,130.0,131.2,131.5,131.7,132.3,132.5$, 133.1, 134.7, 138.0, 138.5, 139.0, 140.6, 141.6, 142.8, 143.1, 184.2; IR (KBr) 2954, 2926, 2856, 1672 , 1457, 930, $827 \mathrm{~cm}^{-1}$; Anal. Calcd for $\mathrm{C}_{47} \mathrm{H}_{60} \mathrm{OS}_{4}$ : C, 73.38; H, 7.86. Found: C, 73.77; H, 7.72.

\section{7-(\{4,5-Dihexylbenzo[1,2-b:4,3-b’ ]dithiophene-2-yl\}ethenyl)-4,5-Dihexyl-benzo[1,2-b:4,3-}

$b^{\prime}$ ]dithiophene-2-methyltriphenylphosphonium bromide (33). To a stirred solution of alcohol 31 $(0.15 \mathrm{~g}, 0.19 \mathrm{mmol})$ in a mixture of acetonitrile $(7 \mathrm{~mL})$ and toluene $(2 \mathrm{~mL})$ was added triphenylphosphine hydrobromide $(77 \mathrm{mg}, 0.23 \mathrm{mmol})$, and the mixture was heated under reflux for 24 h. The solvent was evaporated and the residue was purified by silica gel column chromatography (chloroform and then chloroform-ethanol $(20: 1))$ to give $33(0.15 \mathrm{~g}, 73 \%)$ as a yellowish orange solid. This product was used for the following reaction without further purification.

7-Bromo-4,5-Dihexylbenzo[1,2-b:4,3- $\left.b^{\prime}\right]$ dithiophene-2-carboxaldehyde (34). To a stirred solution of aldehyde 24 (1.50 g, $3.88 \mathrm{mmol})$ in dry DMF (15 mL) was added NBS (0.76 g, $4.27 \mathrm{mmol})$ under argon and the mixture was stirred at room temperature for $2 \mathrm{~h}$. After aqueous $\mathrm{Na}_{2} \mathrm{~S}_{2} \mathrm{O}_{3}$ was added, the organic layer was separated. The aqueous layer was extracted with ethyl acetate. The combined organic phases were washed with brine, dried over $\mathrm{Na}_{2} \mathrm{SO}_{4}$ and concentrated. The crude product was purified by silica gel column chromatography (10:1, hexane-ethyl acetate) to give 34 as a bright yellow solid (1.21 g, 67\%). $\operatorname{mp} 97{ }^{\circ} \mathrm{C} ;{ }^{1} \mathrm{H} \mathrm{NMR}\left(\mathrm{CDCl}_{3}\right) \delta 0.91(\mathrm{t}, J=7.0 \mathrm{~Hz}, 6 \mathrm{H}), 1.33-1.51(\mathrm{~m}, 12 \mathrm{H}), 1.66-$ $1.76(\mathrm{~m}, 4 \mathrm{H}), 2.93(\mathrm{~m}, 4 \mathrm{H}), 7.70(\mathrm{~s}, 1 \mathrm{H}), 8.24(\mathrm{~s}, 1 \mathrm{H}), 10.11(\mathrm{~s}, 1 \mathrm{H}) ;{ }^{13} \mathrm{C} \mathrm{NMR}\left(\mathrm{CDCl}_{3}\right) \delta 22.5,29.5$, $29.6,29.8,31.5,32.0,32.7,115.5,125.0,131.0,131.9,133.9,134.1,140.5,141.9,143.0,184.2$; $\mathrm{IR}(\mathrm{KBr}) 1103,1665,1678,2856,2925,2953 \mathrm{~cm}^{-1}$; Anal. Calcd for $\mathrm{C}_{23} \mathrm{H}_{29} \mathrm{BrOS}_{2}$ : C,59.34; H,6.28. Found: C, 59.18; H, 6.38. 2-Bromo-7-vinyl-4,5-Dihexylbenzo[1,2-b:4,3- $\left.\boldsymbol{b}^{\prime}\right]$ dithiophene (35). To a stirred solution of methyltriphenylphosphonium bromide $(0.47 \mathrm{~g}, 1.28 \mathrm{mmol})$ in $\mathrm{THF}(15 \mathrm{~mL})$ was added $n$-BuLi $\left(1.18 \mathrm{mmol}, 0.77 \mathrm{~mL}\right.$ of $1.58 \mathrm{M}$ solution in hexane) at $0{ }^{\circ} \mathrm{C}$ and the mixture was stirred for $1 \mathrm{~h}$. To the resulting solution was added a solution of $34(0.50 \mathrm{~g}, 1.07 \mathrm{mmol})$ in THF $(2 \mathrm{~mL})$, and the reaction mixture was allowed to warm to room temperature and stirred for $5 \mathrm{~h}$. The reaction was 
quenched by water. The organic layer was separated and the aqueous layer was extracted with ethyl acetate. The organic extracts were washed with brine, dried over $\mathrm{Na}_{2} \mathrm{SO}_{4}$ and concentrated. The crude product was purified by silica gel column chromatography (hexane) to give 35 as a white solid ( $0.42 \mathrm{~g}$, 85\%). $\operatorname{mp~82-84~}{ }^{\circ} \mathrm{C} ;{ }^{1} \mathrm{H}$ NMR $\left(\mathrm{CDCl}_{3}\right) \delta 0.92(\mathrm{t}, J=6.0 \mathrm{~Hz}, 6 \mathrm{H}), 1.33-1.54(\mathrm{~m}, 12 \mathrm{H}), 1.64-1.76(\mathrm{~m}$, 4H), 2.83-2.92 (m, 4H), $5.30(\mathrm{~d}, J=10.8 \mathrm{~Hz}, 1 \mathrm{H}), 5.70(\mathrm{~d}, J=17.1 \mathrm{~Hz}, 1 \mathrm{H}), 6.93(\mathrm{dt}, J=10.8,17.1 \mathrm{~Hz}$, 1H), $7.39(\mathrm{~s}, 1 \mathrm{H}), 7.57(\mathrm{~s}, 1 \mathrm{H}) ;{ }^{13} \mathrm{C} \mathrm{NMR}\left(\mathrm{CDCl}_{3}\right) \delta$ 22.6, 29.6, 29.7, 29.8, 31.6, 32.2, 32.3, 113.7, 115.4, 121.3, 125.4, 130.2, 130.6, 132.1, 132.4, 137.8, 142.2; IR(KBr) 902, 931, 972, 1103, 1615, 2856, 2926, $2954 \mathrm{~cm}^{-1}$; Anal. Calcd for $\mathrm{C}_{24} \mathrm{H}_{31} \mathrm{BrS}_{2}$ : C, 62.19; H, 6.74. Found: C, 61.90; H, 6.71.

2-Iodo-4,5-dihexylbenzo[1,2-b:4,3- $\left.\boldsymbol{b}^{\prime}\right]$ dithiophene (36). To a stirred solution of 15 (2.00 g, 5.58 mmol) in THF $(60 \mathrm{~mL})$ was added $n$-BuLi $(6.14 \mathrm{mmol}, 4.1 \mathrm{~mL}$ of $1.50 \mathrm{M}$ solution in hexane $)$ at $-78{ }^{\circ} \mathrm{C}$ and the mixture was stirred for $2 \mathrm{~h}$. To the resulting yellow solution was added a solution of iodine $(1.56 \mathrm{~g}, 1.74 \mathrm{mmol})$ in THF $(10 \mathrm{~mL})$ at $-78{ }^{\circ} \mathrm{C}$. The reaction mixture was allowed to warm to room temperature and stirred for $2.5 \mathrm{~h}$. The reaction was quenched by aqueous solution of $\mathrm{Na}_{2} \mathrm{~S}_{2} \mathrm{O}_{3}$. The organic layer was separated and the aqueous layer was extracted with ethyl acetate. The organic extracts were washed with brine, dried over $\mathrm{Na}_{2} \mathrm{SO}_{4}$ and concentrated. The residue was chromatographed on silica gel using hexane as an eluent to give 36 as a white solid (2.20 g, 81\%). mp 97-100 ${ }^{\circ} \mathrm{C} ;{ }^{1} \mathrm{H}$ NMR $\left(\mathrm{CDCl}_{3}\right) \delta 0.92(\mathrm{t}, J=6.9 \mathrm{~Hz}, 6 \mathrm{H}), 1.28-1.37(\mathrm{~m}, 8 \mathrm{H}), 1.45-1.52(\mathrm{~m}, 4 \mathrm{H}), 1.67-$ $1.72(\mathrm{~m}, 4 \mathrm{H}), 2.87-2.98(\mathrm{~m}, 4 \mathrm{H}), 7.47(\mathrm{~d}, J=5.4 \mathrm{~Hz}, 1 \mathrm{H}), 7.56(\mathrm{~d}, J=5.4 \mathrm{~Hz}, 1 \mathrm{H}), 7.85(\mathrm{~s}, 1 \mathrm{H}) ;{ }^{13} \mathrm{C}$ $\operatorname{NMR}\left(\mathrm{CDCl}_{3}\right) \delta 14.1,22.6,29.7,29.8,31.6,32.3,122.2,125.4,129.4,130.7,131.3,132.4,133.8,138.8$, 143.4; IR (KBr) 2955, 2926, 2856, 1470, 837, 822, $710 \mathrm{~cm}^{-1}$; Anal. Calcd for $\mathrm{C}_{22} \mathrm{H}_{29} \mathrm{IS}_{2}: \mathrm{C}, 54.54$; H, 6.03. Found: C, 54.62; H, 6.33.

2-[(Trimethylsilyl)ethynyl]-4,5-dihexylbenzo[1,2-b:4,3-b’ $]$ dithiophene (37). To a stirred solution of $36(0.50 \mathrm{~g}, 1.03 \mathrm{mmol})$ in $\mathrm{THF}(20 \mathrm{~mL})$ were added diisopropylamine $(0.21 \mathrm{~mL}, 1.5 \mathrm{mmol})$, trimethylsilylacetylene $(0.16 \mathrm{~mL}, 1.1 \mathrm{mmol})$, bis(triphenylphosphine)palladium(II) dichloride $(70 \mathrm{mg}$, $0.10 \mathrm{mmol})$ and copper(I) iodide $(10 \mathrm{mg}, 0.050 \mathrm{mmol})$, and the mixture was stirred for $20 \mathrm{~h}$ at room 
temperature. The reaction was quenched by water. The organic layer was separated and the aqueous layer was extracted with dichloromethane. The reaction mixture was washed with water, aqueous $\mathrm{NaHCO}_{3}$ solution and brine, and dried over $\mathrm{Na}_{2} \mathrm{SO}_{4}$, and concentrated. The crude product was chromatographed on silica gel using hexane as an eluent to give $37(0.45 \mathrm{~g}, 96 \%)$ as brown solid. ${ }^{1} \mathrm{H}$ $\operatorname{NMR}\left(\mathrm{CDCl}_{3}\right) \delta 0.29(\mathrm{~s}, 9 \mathrm{H}), 0.92(\mathrm{t}, J=6.9 \mathrm{~Hz}, 6 \mathrm{H}), 1.28-1.37(\mathrm{~m}, 8 \mathrm{H}), 1.45-1.52(\mathrm{~m}, 4 \mathrm{H}), 1.67-1.72$ (m, 4H), 2.87-2.98 (m, 4H), $7.47(\mathrm{~d}, J=5.4 \mathrm{~Hz}, 1 \mathrm{H}), 7.56(\mathrm{~d}, J=5.4 \mathrm{~Hz}, 1 \mathrm{H}), 7.85(\mathrm{~s}, 1 \mathrm{H})$.

2-Ethynyl-4,5-hexylbenzo[1,2-b:4,3-b']dithiophene (38). To a stirred solution of 37 (0.36 g, 0.79 $\mathrm{mmol})$ in a mixture of methanol $(40 \mathrm{~mL})$ and THF $(20 \mathrm{~mL})$ was added potassium carbonate $(0.33 \mathrm{~g}$, $2.37 \mathrm{mmol}$ ) and this mixture was stirred for $17 \mathrm{~h}$ at room temperature. The combined organic phase was extracted with dichloromethane and successively washed with water, aqueous $\mathrm{NaHCO}_{3}$ solution and brine, and dried over $\mathrm{Na}_{2} \mathrm{SO}_{4}$, and concentrated. The crude product was chromatographed on silica gel using hexane as an eluent to give $38(0.22 \mathrm{~g}, 73 \%)$ as brown solid. ${ }^{1} \mathrm{H} \mathrm{NMR}\left(\mathrm{CDCl}_{3}\right) \delta 0.91(\mathrm{t}, J=$ $7.2 \mathrm{~Hz}, 6 \mathrm{H}), 1.30-1.38(\mathrm{~m}, 8 \mathrm{H}), 1.47-1.53(\mathrm{~m}, 4 \mathrm{H}), 1.66-1.78(\mathrm{~m}, 4 \mathrm{H}), 2.94(\mathrm{t}, J=7.1 \mathrm{~Hz}, 4 \mathrm{H}), 3.45(\mathrm{~s}$ 1H), $7.51(\mathrm{~d}, J=5.1 \mathrm{~Hz}, 1 \mathrm{H}), 7.61(\mathrm{~d}, J=5.1 \mathrm{~Hz}, 1 \mathrm{H}), 7.84(\mathrm{~s}, 1 \mathrm{H})$.

\section{2,7-Di[(trimethylsilyl)ethynyl]-4,5-dihexylbenzo[1,2-b:4,3- $\left.b^{\prime}\right]$ dithiophene (39). To a stirred} solution of $23(2.00 \mathrm{~g}, 3.26 \mathrm{mmol})$ in THF (40 mL) were added diisopropylamine $(1.4 \mathrm{~mL}, 9.8 \mathrm{mmol})$, trimethylsilylacetylene $(1.0 \mathrm{~mL}, 7.2 \mathrm{mmol})$, bis(triphenylphosphine)palladium(II) dichloride $(0.23 \mathrm{~g}$, $0.33 \mathrm{mmol})$ and copper(I) iodide $(30 \mathrm{mg}, 0.20 \mathrm{mmol})$, and the mixture was stirred for $12 \mathrm{~h}$ at room temperature. The reaction was quenched by water. The organic layer was separated and the aqueous layer was extracted with dichloromethane. The combined organic phase was washed with water, aqueous $\mathrm{NaHCO}_{3}$ solution and brine, and dried over $\mathrm{Na}_{2} \mathrm{SO}_{4}$, and concentrated. The crude product was chromatographed on silica gel using hexane as an eluent to give 39 (1.63 g, 91\%) as brown solid. mp 129-131 ${ }^{\circ} \mathrm{C} ;{ }^{1} \mathrm{H}$ NMR $\left(\mathrm{CDCl}_{3}\right) \delta 0.29(\mathrm{~s}, 18 \mathrm{H}), 0.91(\mathrm{t}, J=7.1 \mathrm{~Hz}, 6 \mathrm{H}), 1.33-1.37(\mathrm{~m}, 8 \mathrm{H}), 1.45-1.50$ $(\mathrm{m}, 4 \mathrm{H}), 1.65-1.75(\mathrm{~m}, 4 \mathrm{H}), 2.89(\mathrm{t}, J=8.1 \mathrm{~Hz}, 4 \mathrm{H}), 7.71(\mathrm{~s}, 2 \mathrm{H}) ;{ }^{13} \mathrm{C} \mathrm{NMR}\left(\mathrm{CDCl}_{3}\right) \delta 0.15,14.2,22.8$ 
29.8, 30.0, 31.8, 32.5, 98.2, 101.1, 122.3, 127.9, 131.6, 132.1, 139.7; IR (KBr) 2957, 2927, 2856, 2147,

1470, $1250 \mathrm{~cm}^{-1}$; Anal. Calcd for $\mathrm{C}_{32} \mathrm{H}_{46} \mathrm{~S}_{2} \mathrm{Si}_{2}:$ C, 69.75; H, 8.41. Found: C, 69.49; H, 8.63.

2,7-Diethynyl-4,5-dihexylbenzo[1,2-b:4,3- $\left.\boldsymbol{b}^{\prime}\right]$ dithiophene (40). To a stirred solution of 39 (1.30 g, $2.36 \mathrm{mmol})$ in a mixture of methanol $(70 \mathrm{~mL})$ and THF $(30 \mathrm{~mL})$ was added potassium carbonate $(1.96 \mathrm{~g}$, $14.2 \mathrm{mmol}$ ), and this mixture was stirred for $4.5 \mathrm{~h}$ at room temperature. Water was added and the separated aqueous layer was extracted with ethyl acetate. The combined organic phase was extracted with dichloromethane and successively washed with water, aqueous $\mathrm{NaHCO}_{3}$ solution and brine, and dried over $\mathrm{Na}_{2} \mathrm{SO}_{4}$, and concentrated. The crude product was chromatographed on silica gel using hexane as an eluent to give $40(0.83 \mathrm{~g}, 86 \%)$ as brown solid. $\mathrm{mp} 73-75{ }^{\circ} \mathrm{C} ;{ }^{1} \mathrm{H} \mathrm{NMR}\left(\mathrm{CDCl}_{3}\right) \delta 0.91(\mathrm{t}$, $J=8.1 \mathrm{~Hz}, 6 \mathrm{H}), 1.33-1.38(\mathrm{~m}, 8 \mathrm{H}), 1.43-1.48(\mathrm{~m}, 4 \mathrm{H}), 1.65-1.75(\mathrm{~m}, 4 \mathrm{H}), 2.90(\mathrm{t}, J=7.1 \mathrm{~Hz}, 4 \mathrm{H}), 3.47$ (s, 2H), $7.78(\mathrm{~s}, 2 \mathrm{H}) ;{ }^{13} \mathrm{C} \mathrm{NMR}\left(\mathrm{CDCl}_{3}\right) \delta$ 14.1, 22.6, 29.6, 29.8, 31.6, 32.3, 82.9, 121.1, 128.3, 131.6, 131.7, 139.7; IR (KBr) 3291, 2954, 2928, 2858, 1471, $1205 \mathrm{~cm}^{-1}$; Anal. Calcd for $\mathrm{C}_{26} \mathrm{H}_{30} \mathrm{~S}_{2}$ : C, 76.79; H, 7.44. Found: C, 76.92; H, 7.43.

1,2-Bis(2-iodo-4,5-dihexylbenzo[1,2-b:4,3- $\left.b^{\prime}\right]$ dithiophene-2-yl)acetylene (41). To a stirred solution of $11(0.10 \mathrm{~g}, 0.14 \mathrm{mmol})$ in THF ( $3 \mathrm{~mL})$ was added $n$-BuLi $(0.57 \mathrm{mmol}, 0.36 \mathrm{~mL}$ of $1.59 \mathrm{M}$ solution in hexane) at $0{ }^{\circ} \mathrm{C}$ and the mixture was stirred for $1.5 \mathrm{~h}$. To a resulting yellow solution was added a solution of iodine $(0.17 \mathrm{~g}, 0.68 \mathrm{mmol})$ in $\mathrm{THF}(1 \mathrm{~mL})$ at $0{ }^{\circ} \mathrm{C}$. The reaction mixture was stirred for 2.5 $h$ at room temperature. The reaction was quenched by aqueous $\mathrm{Na}_{2} \mathrm{~S}_{2} \mathrm{O}_{3}$. The organic layer was separated and the aqueous layer was extracted with ethyl acetate. The organic extracts were washed with brine, dried over $\mathrm{Na}_{2} \mathrm{SO}_{4}$ and concentrated. The residue was chromatographed on silica gel using hexane as an eluent. The crude product was recrystallized from hexane and $\mathrm{CHCl}_{3}$ to give $41(81 \mathrm{mg}$, $60 \%)$ as a light yellow solid. $\mathrm{mp} 190-194{ }^{\circ} \mathrm{C} ;{ }^{1} \mathrm{H} \mathrm{NMR}\left(\mathrm{CDCl}_{3}\right) \delta 0.92(\mathrm{t}, J=6.9 \mathrm{~Hz}, 12 \mathrm{H}), 1.35-1.40$ (m, 16H), 1.46-1.52 (m, 8H), 1.66-1.73 (m, 8H), 2.88-2.94 (m, 8H), $7.80(\mathrm{~s}, 2 \mathrm{H}), 7.83(\mathrm{~s}, 2 \mathrm{H})$. 


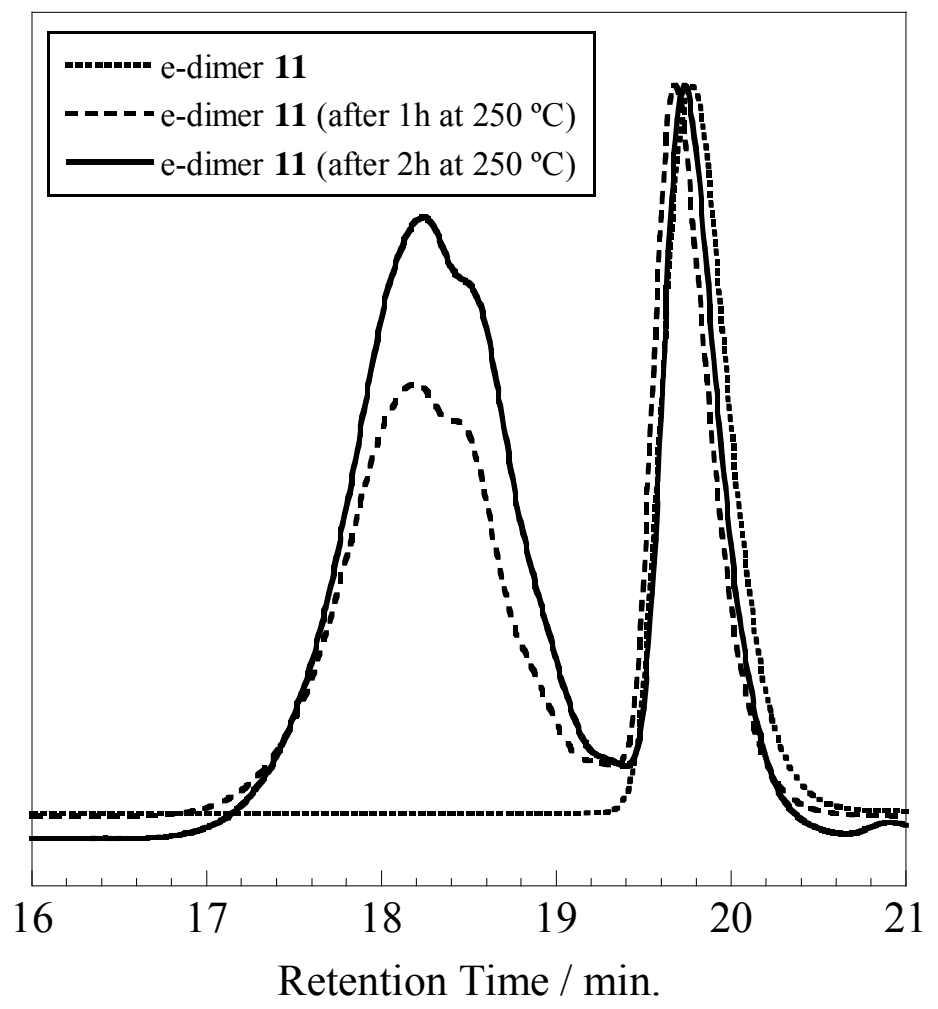

Figure S1. GPC chromatograms of ethynylene-bridged dimer 11 after heating for $0 \mathrm{~h}$ (dotted line), $1 \mathrm{~h}$ (dashed line) and $2 \mathrm{~h}$ (solid line) at $250^{\circ} \mathrm{C}$ 


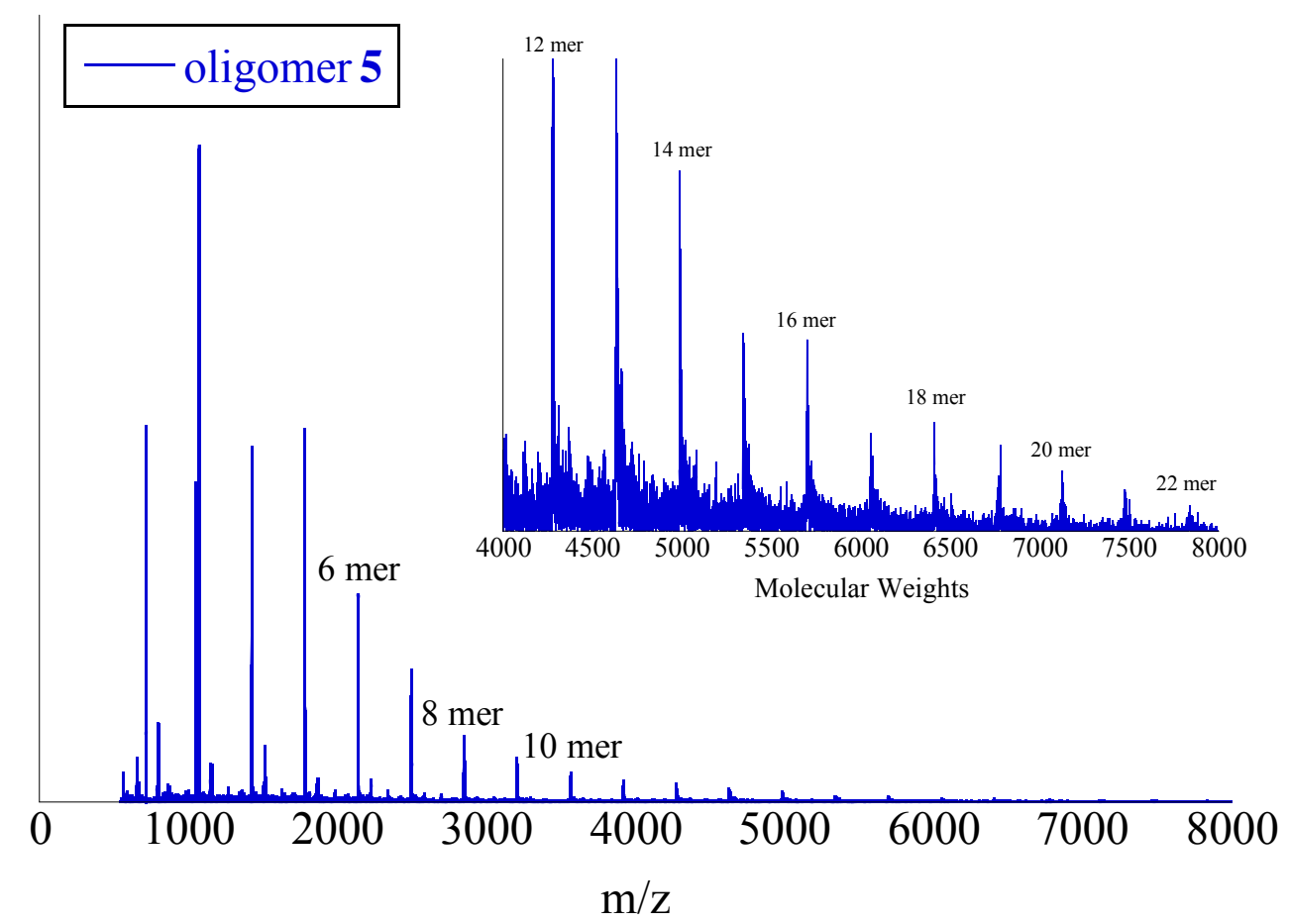

Figure S2. LDI-TOF mass spectra of oligomer 5

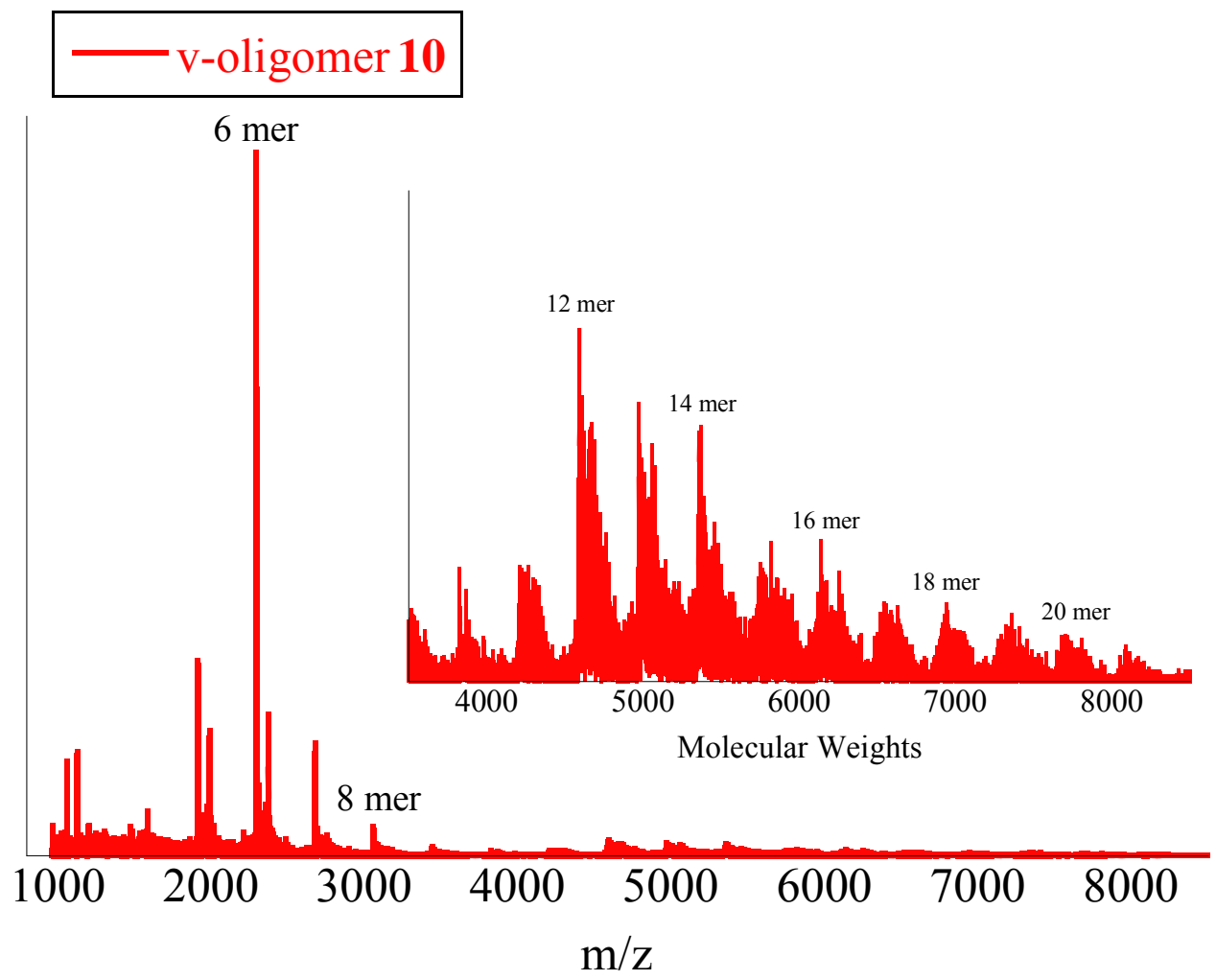

Figure S3. LDI-TOF mass spectra of vinylene-bridged oligomer $\mathbf{1 0}$ 


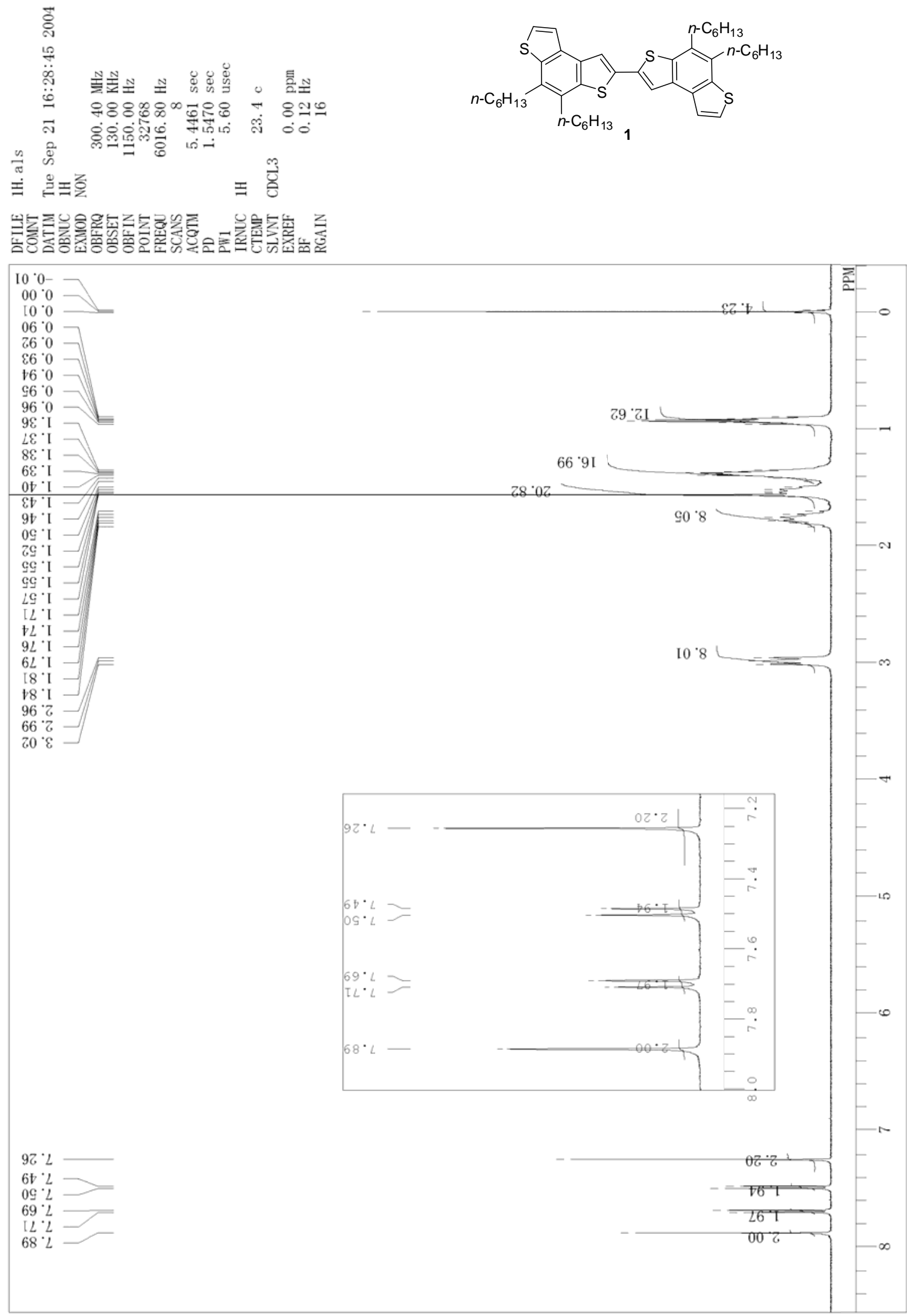




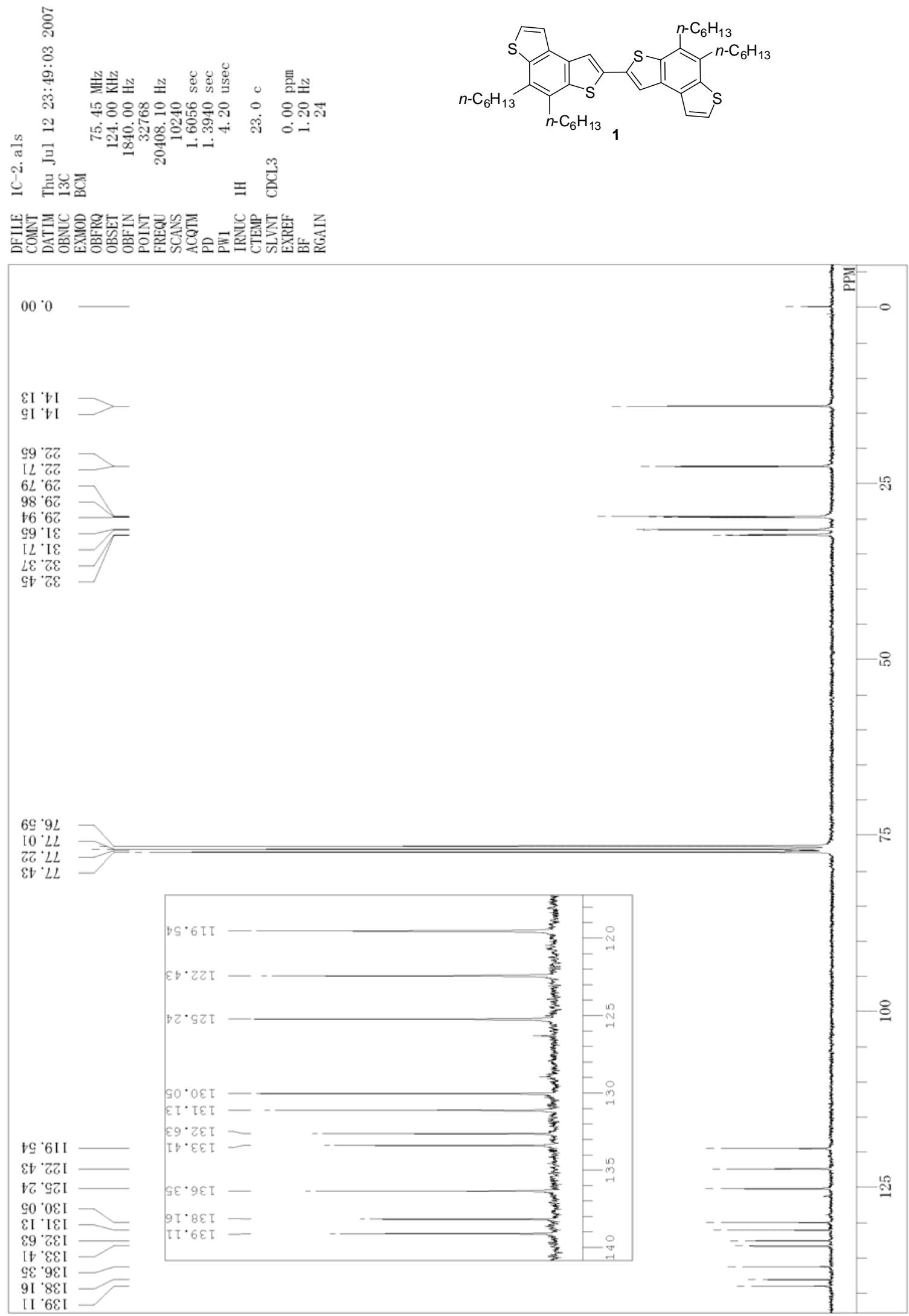



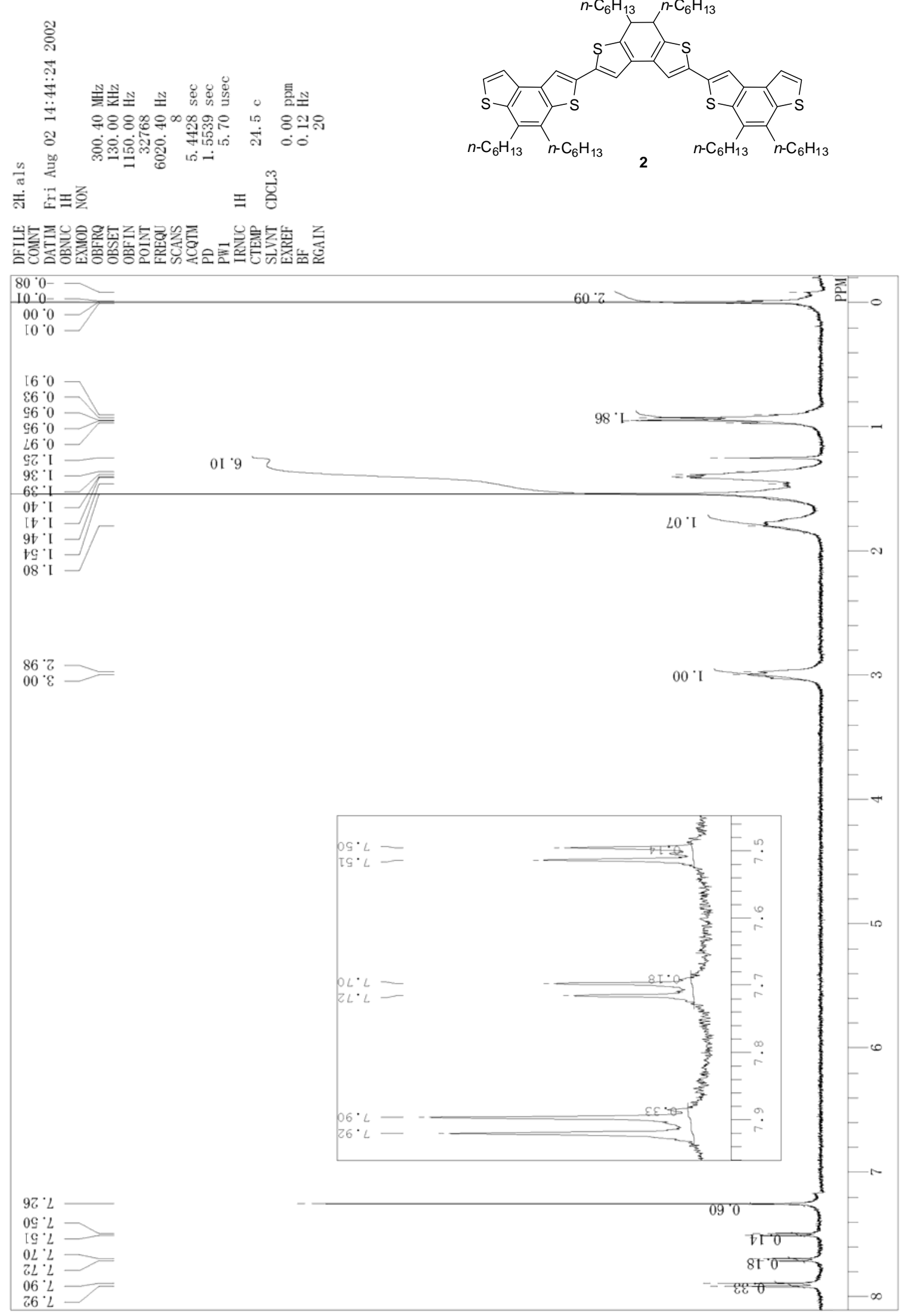

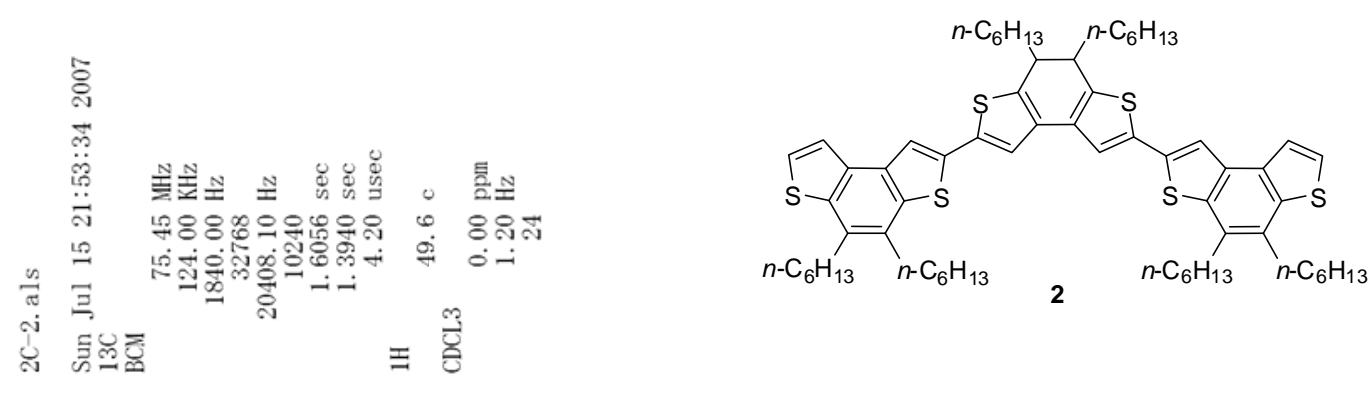

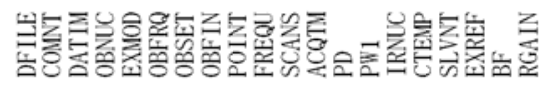

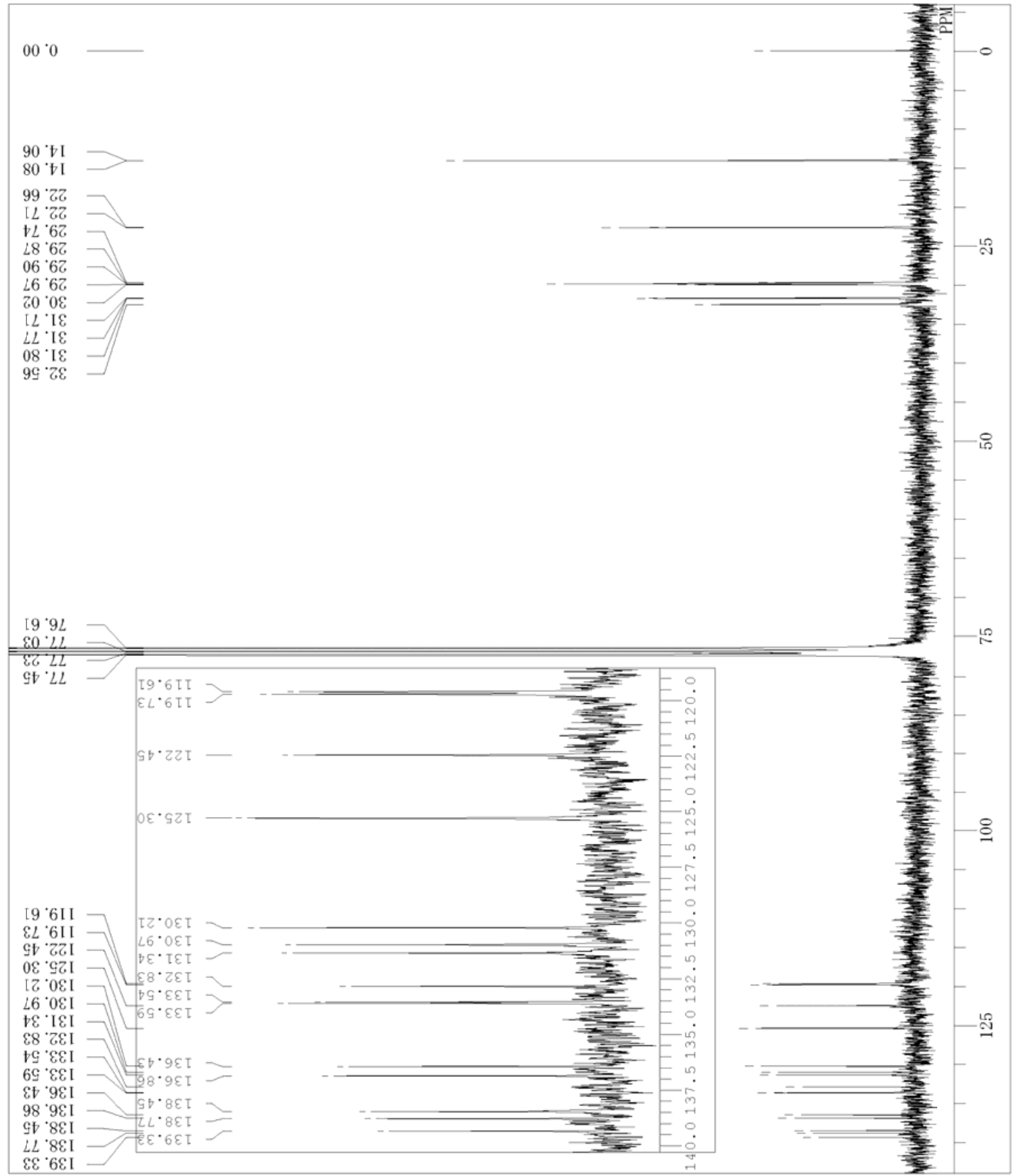




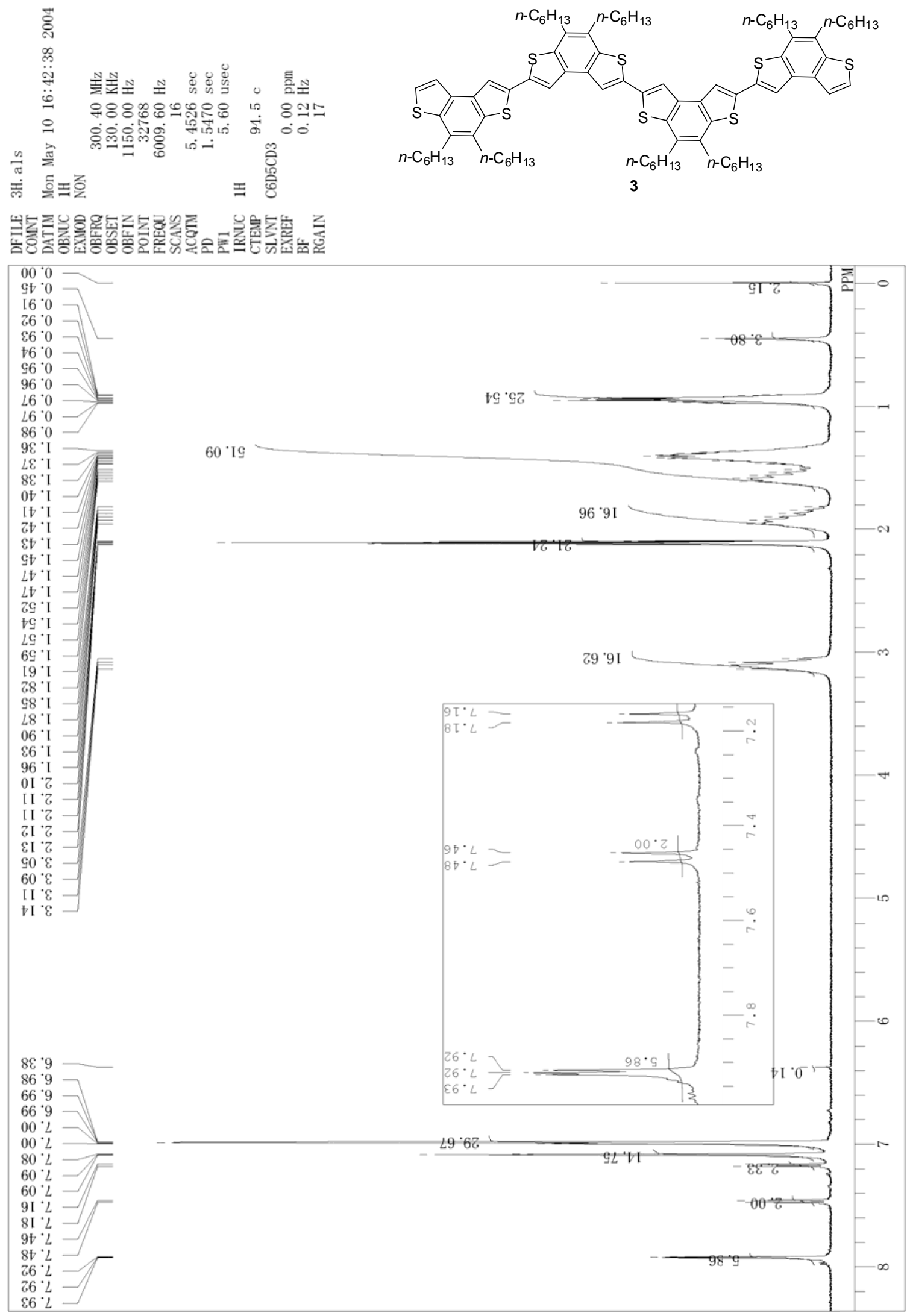



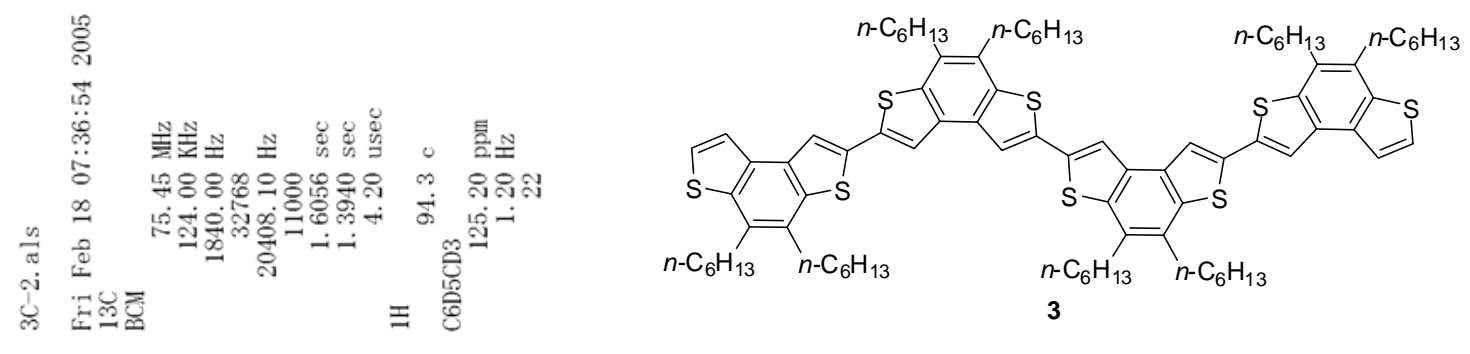

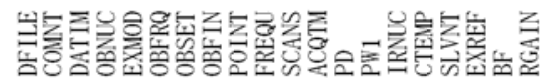

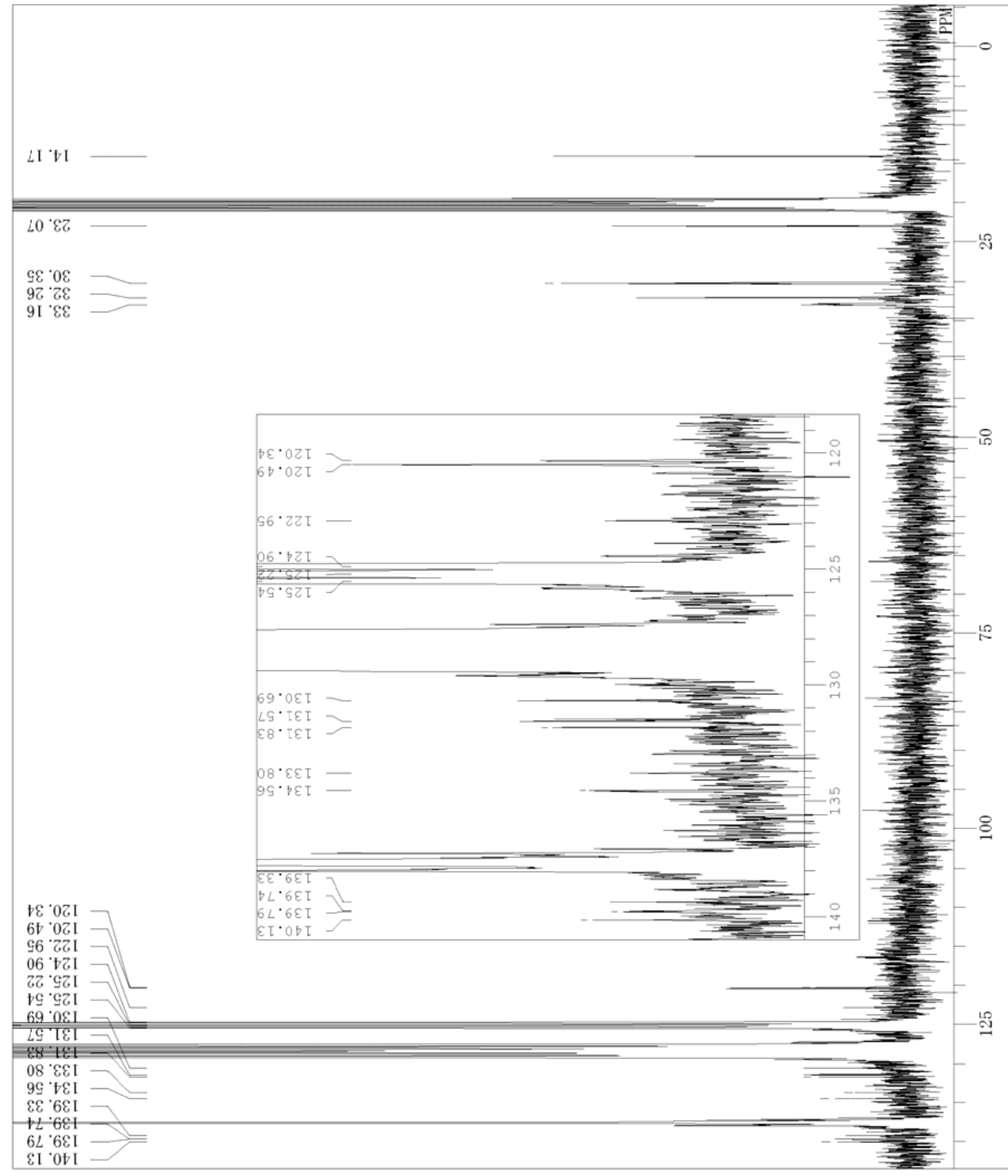



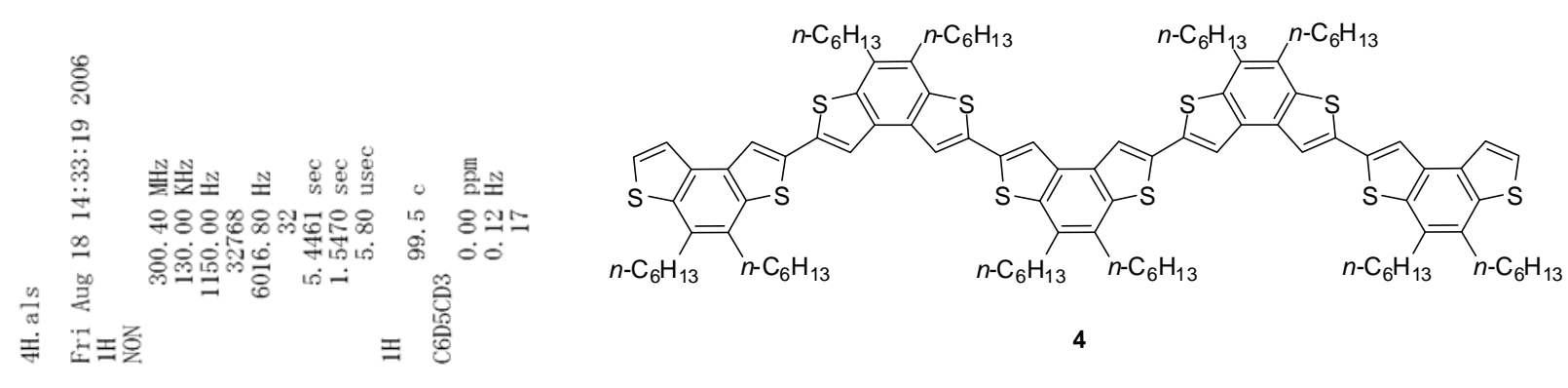

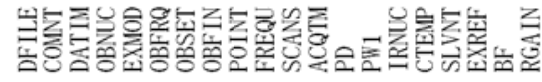

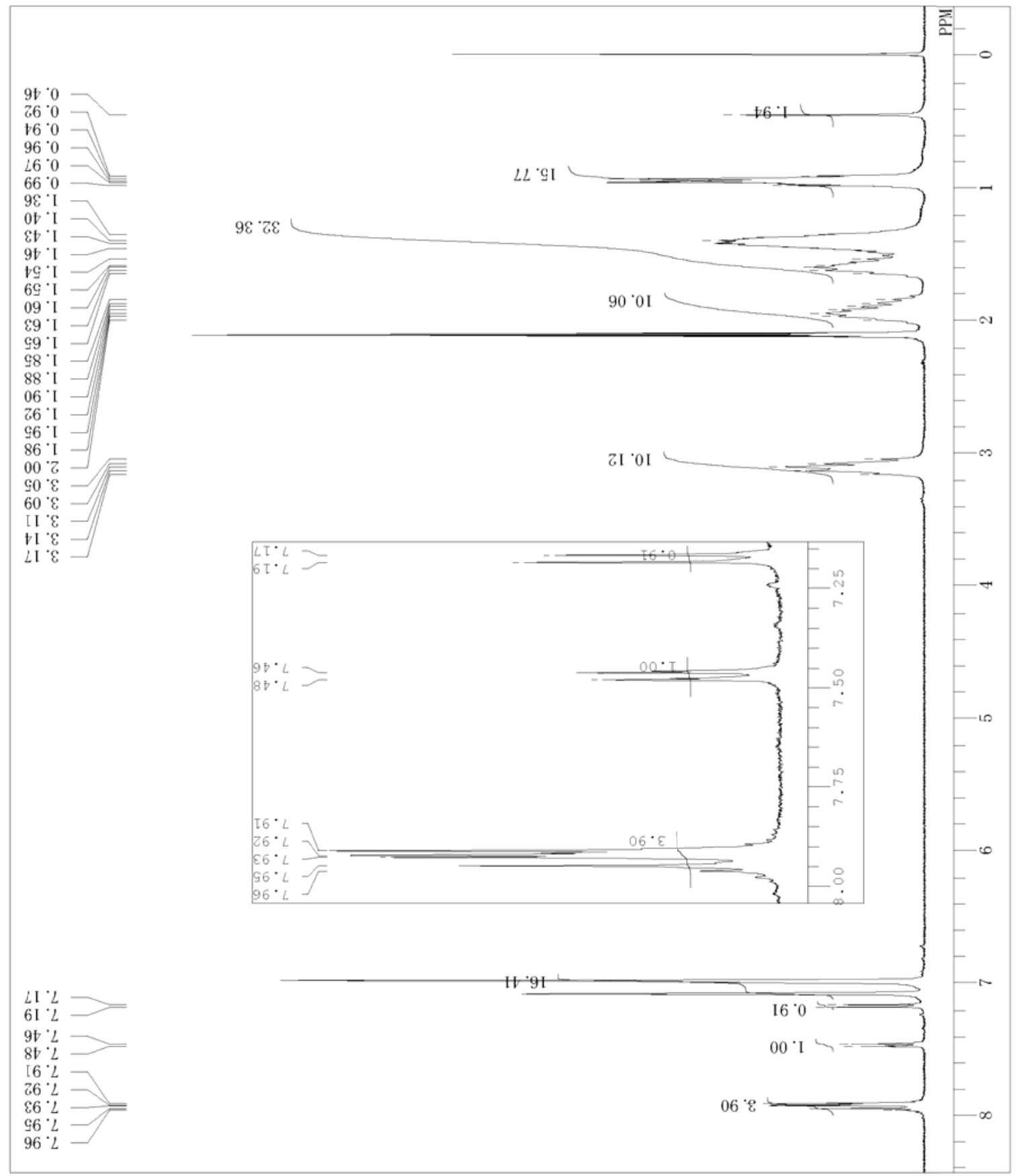



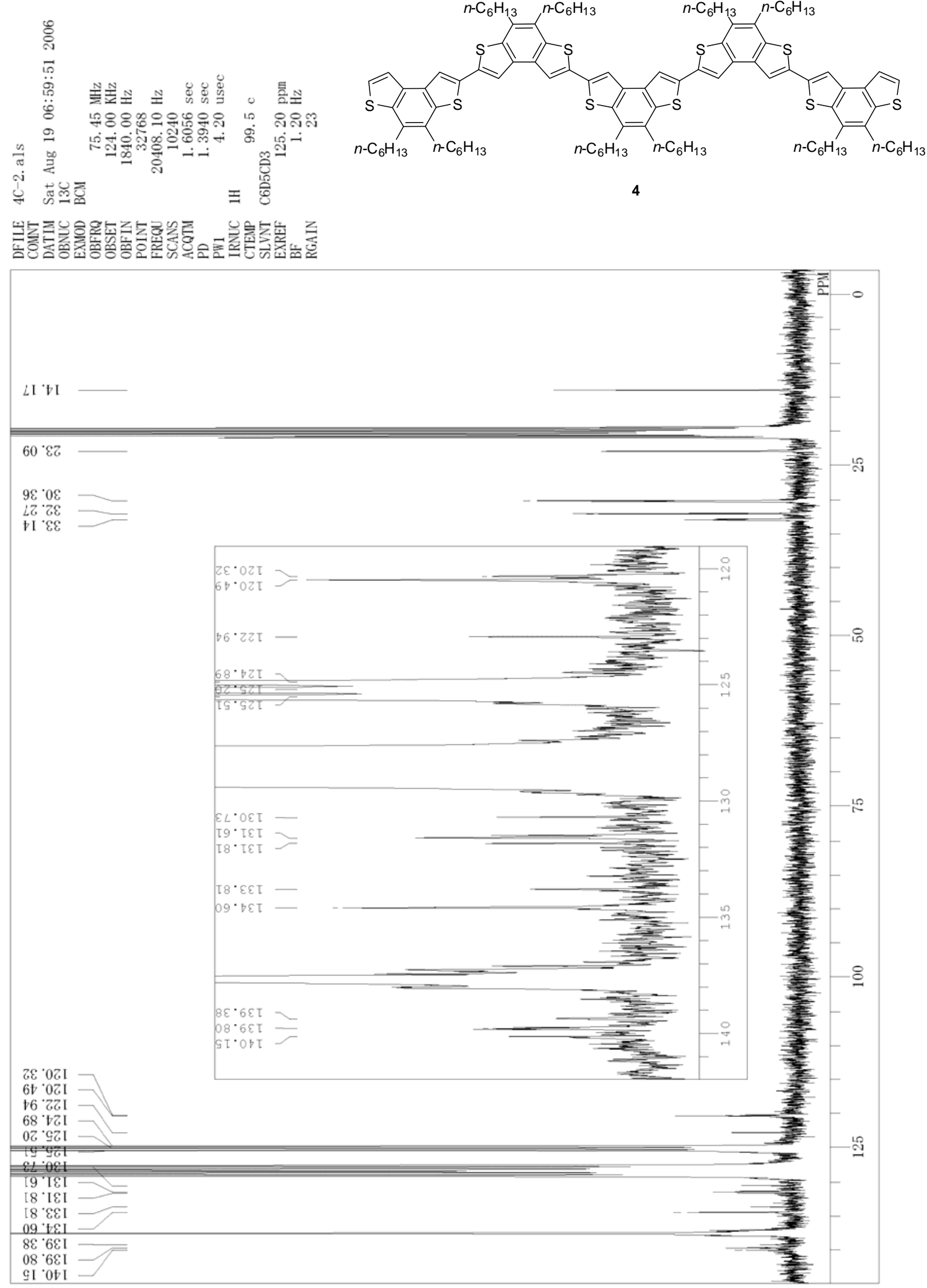


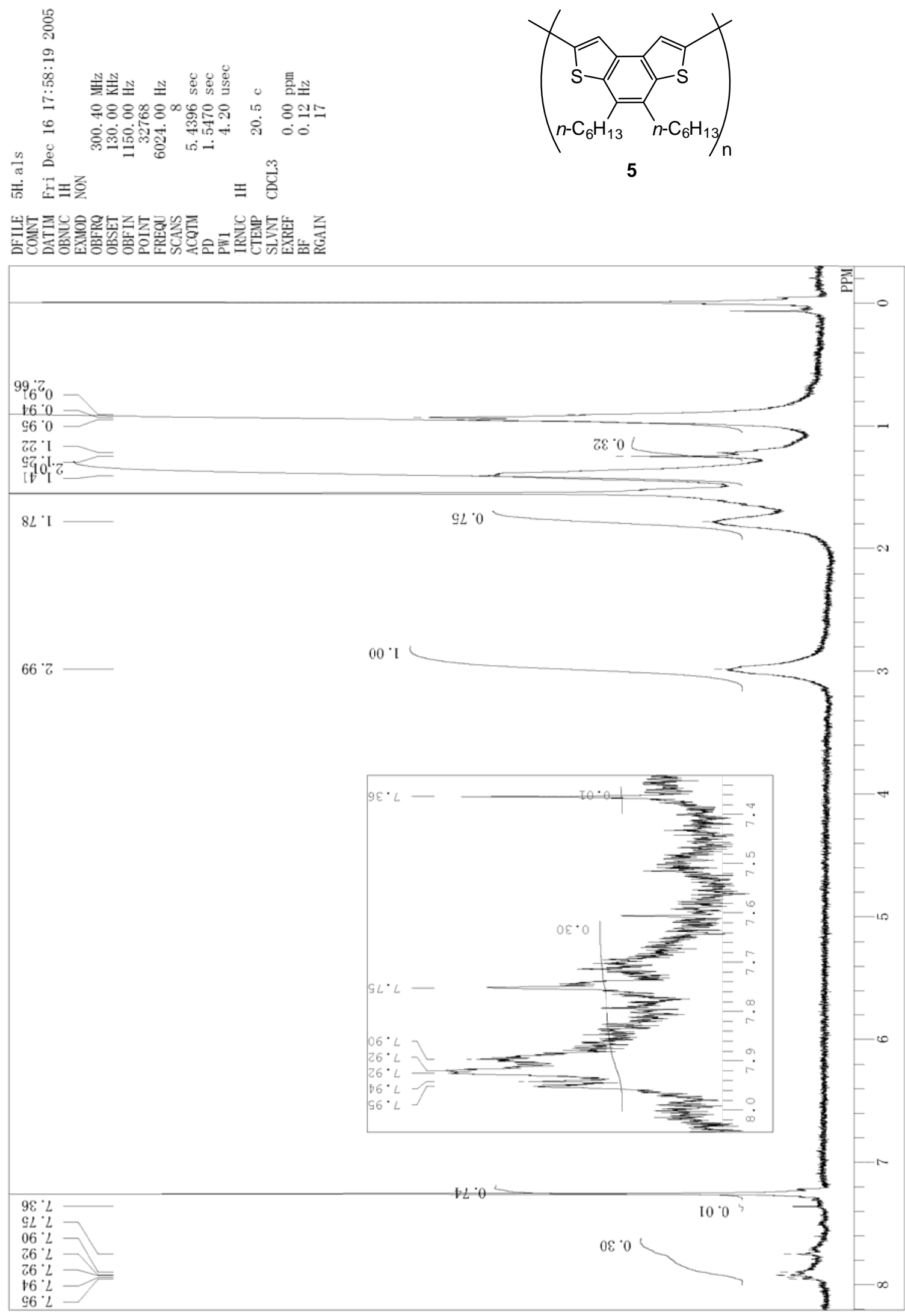




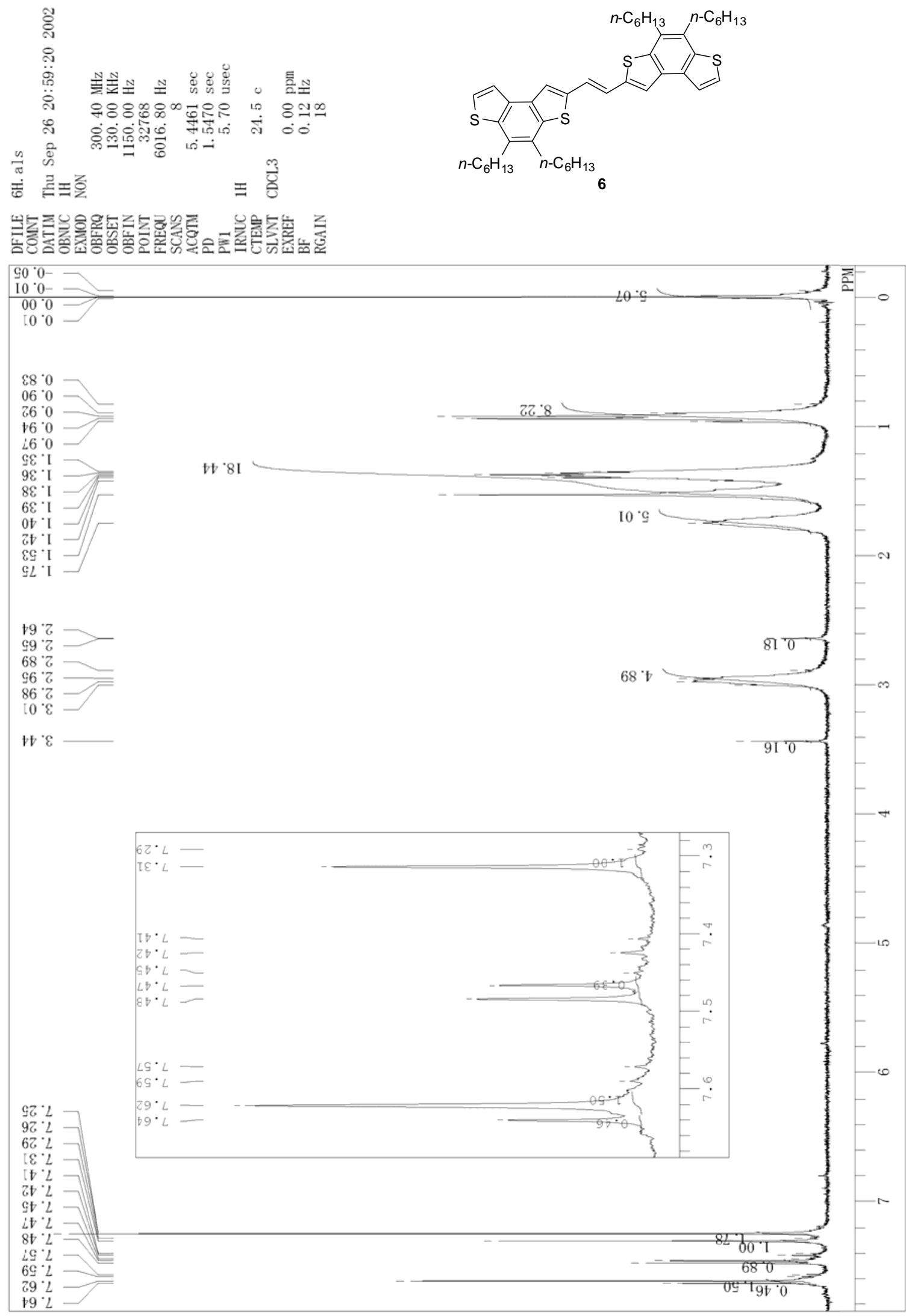




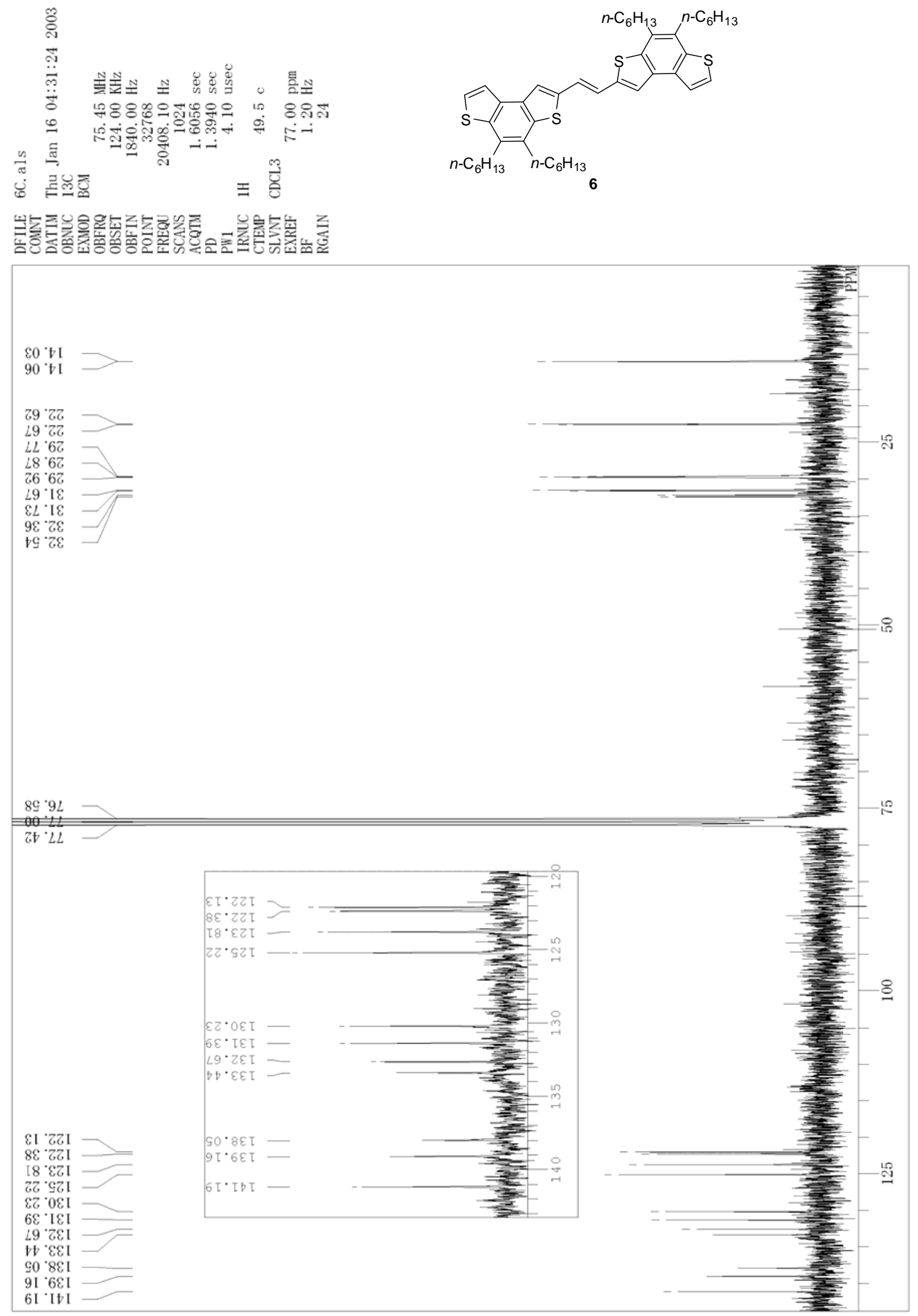




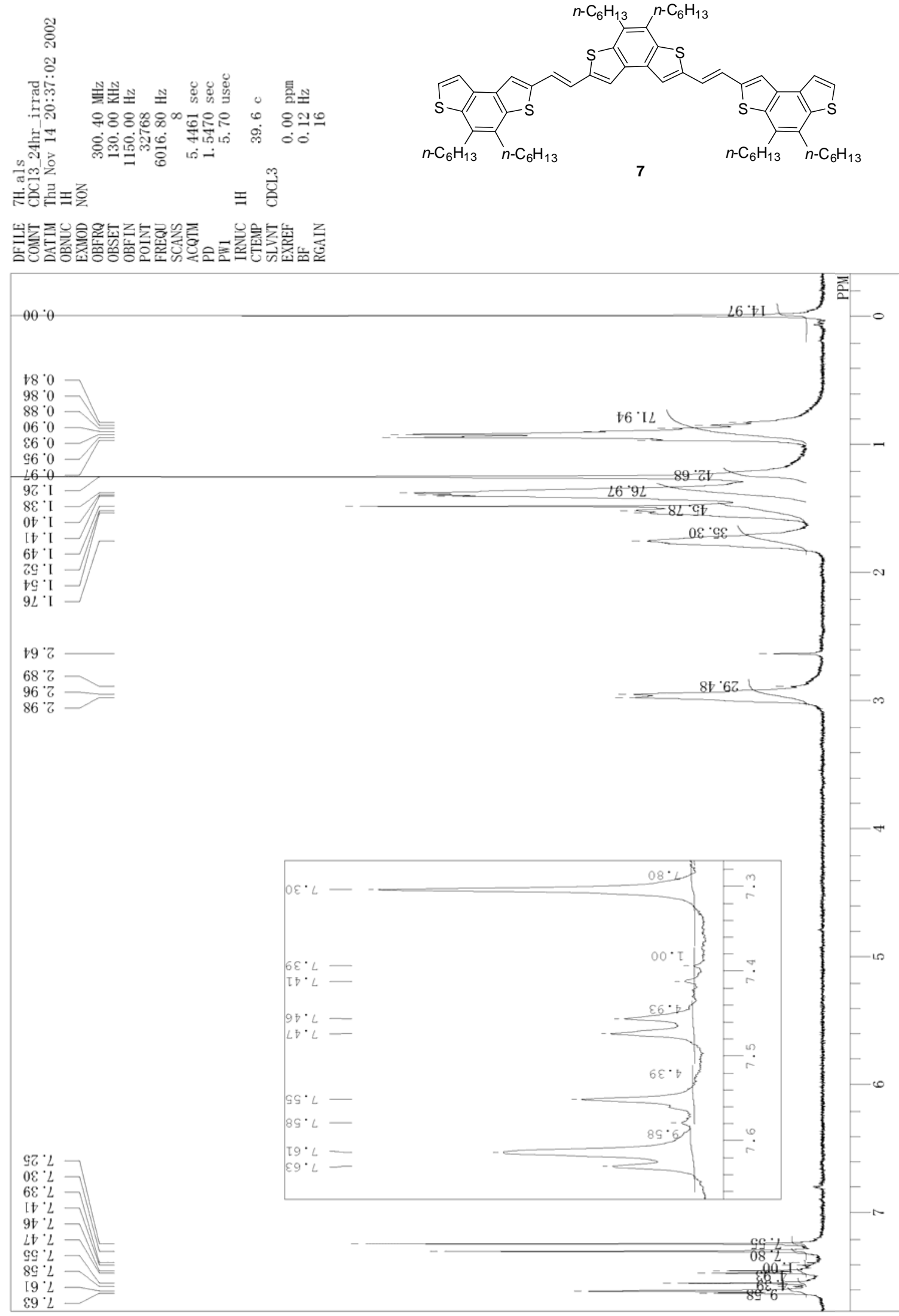




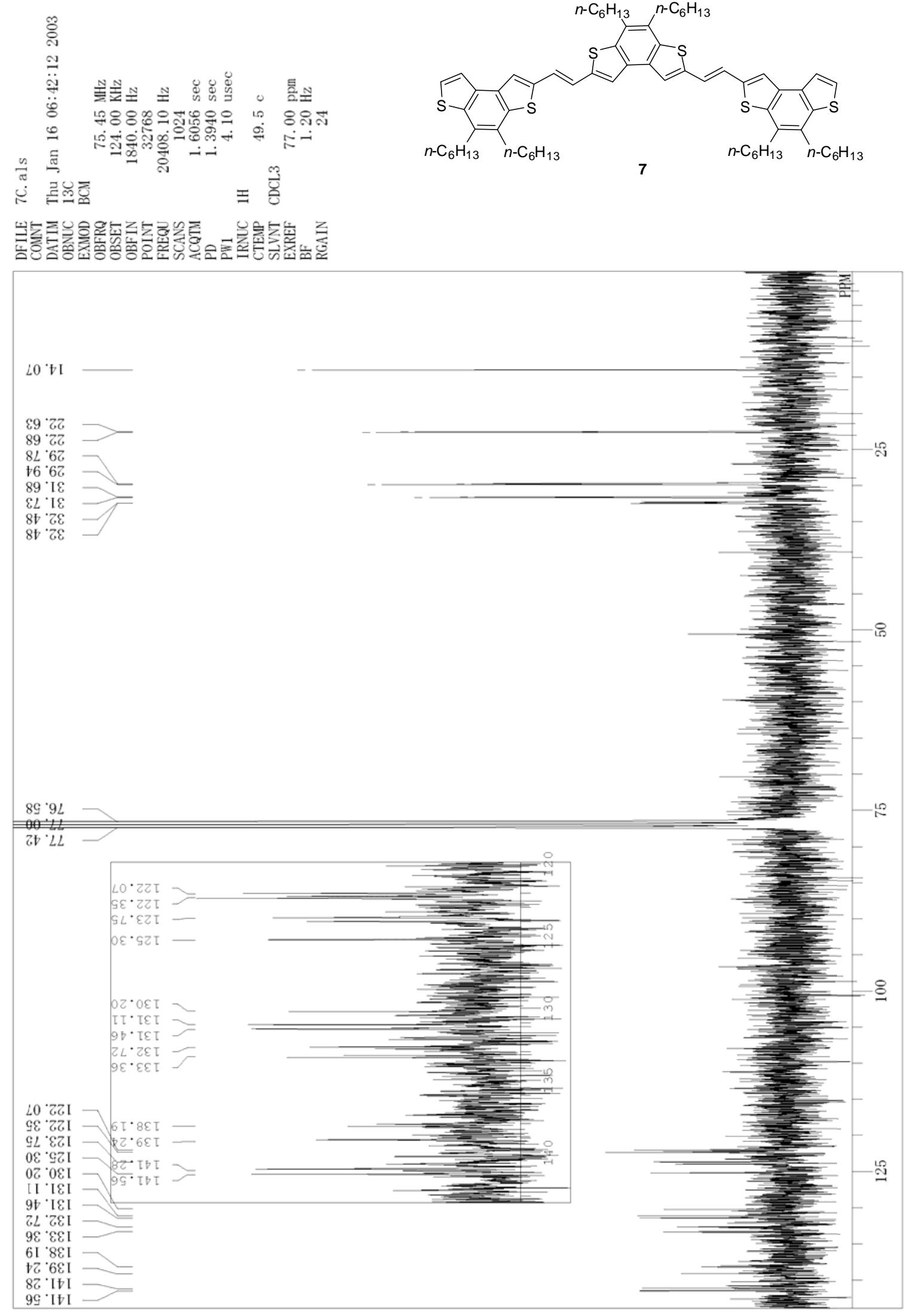




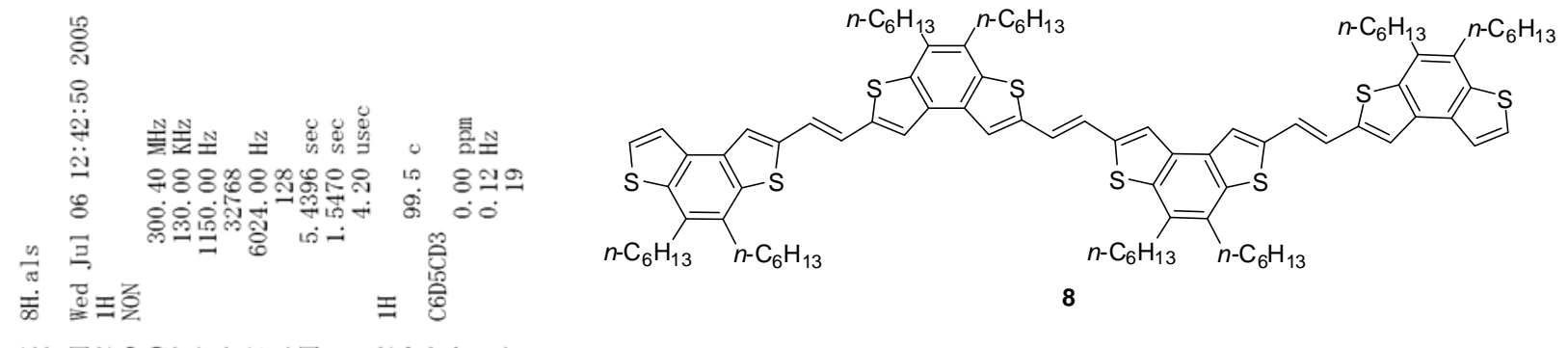

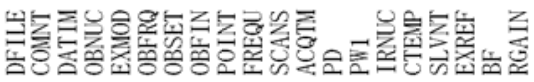
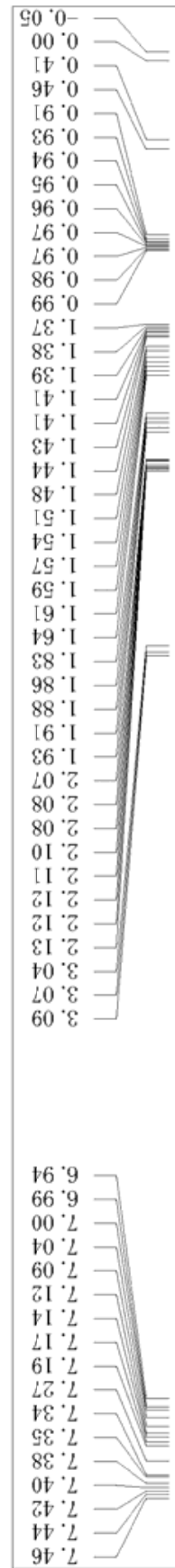

$00^{\circ} \mathrm{c9}$
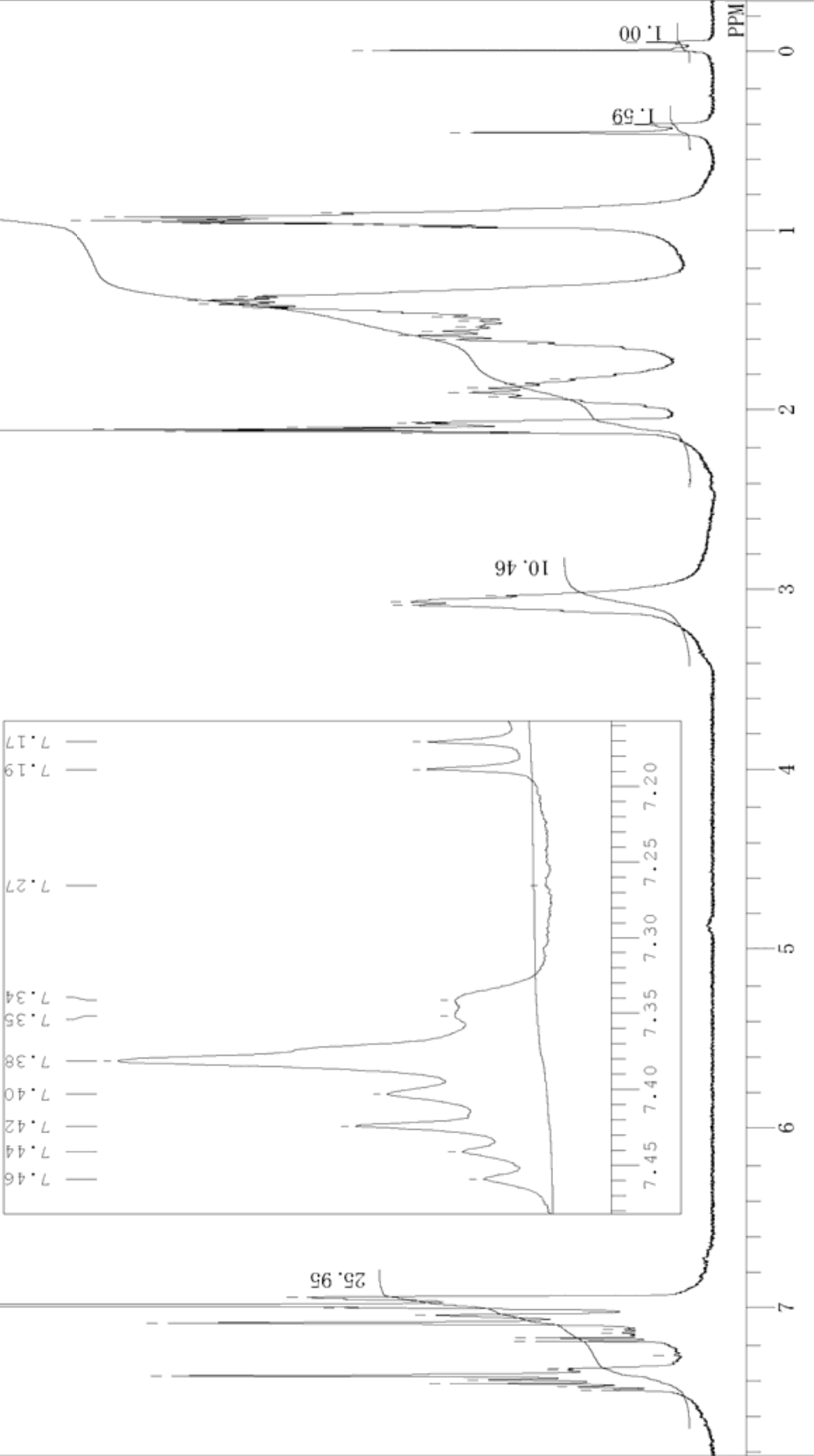

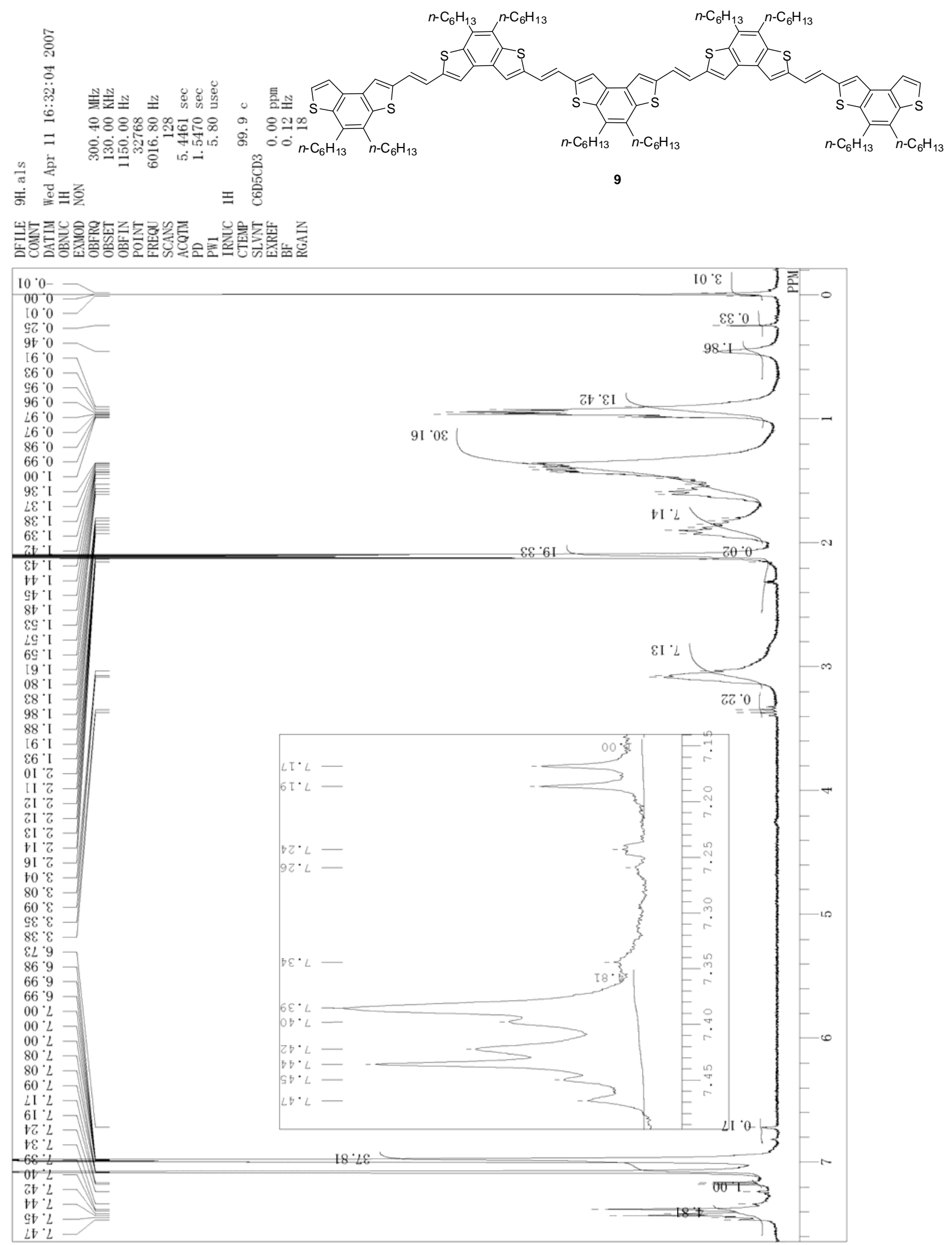


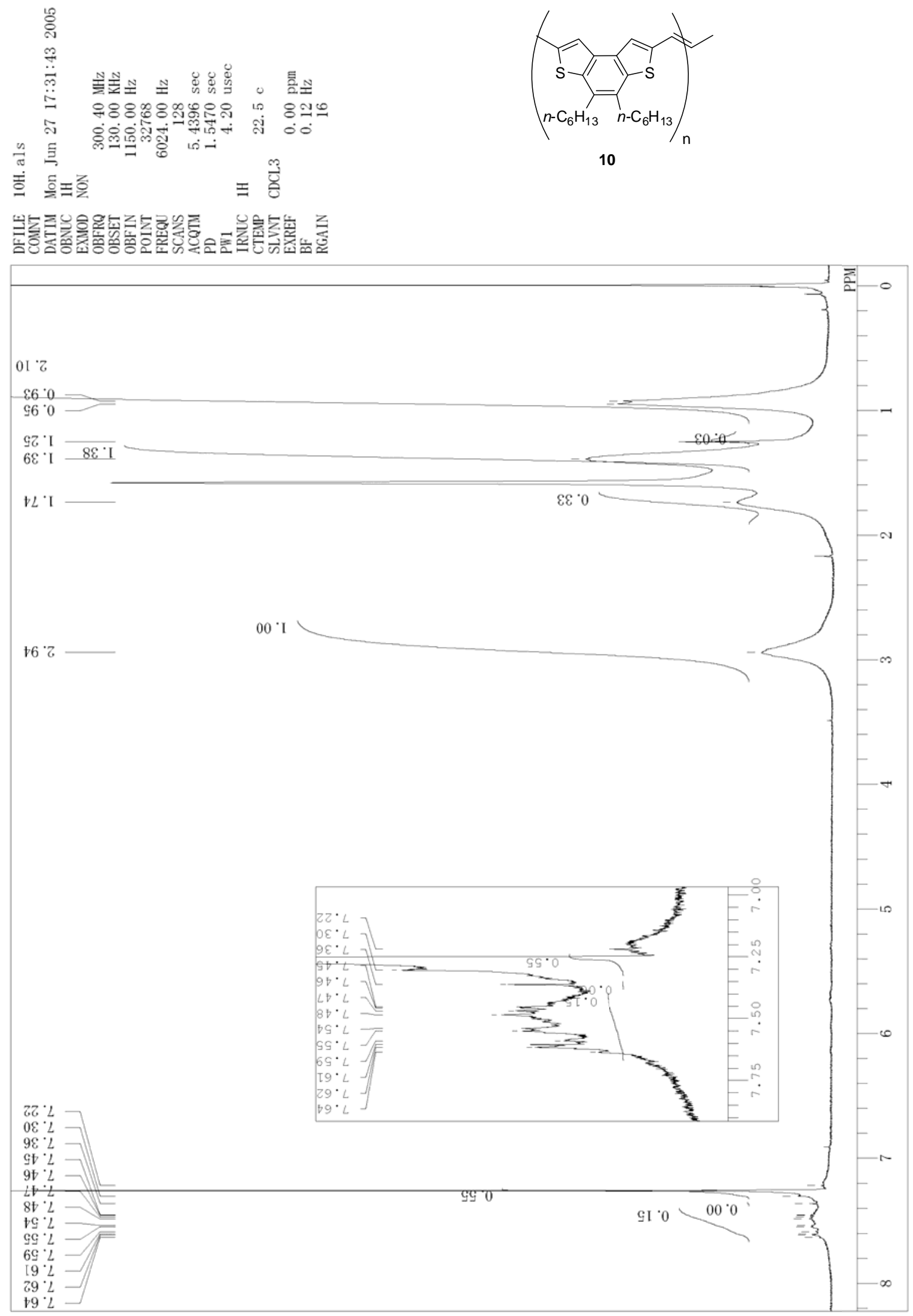




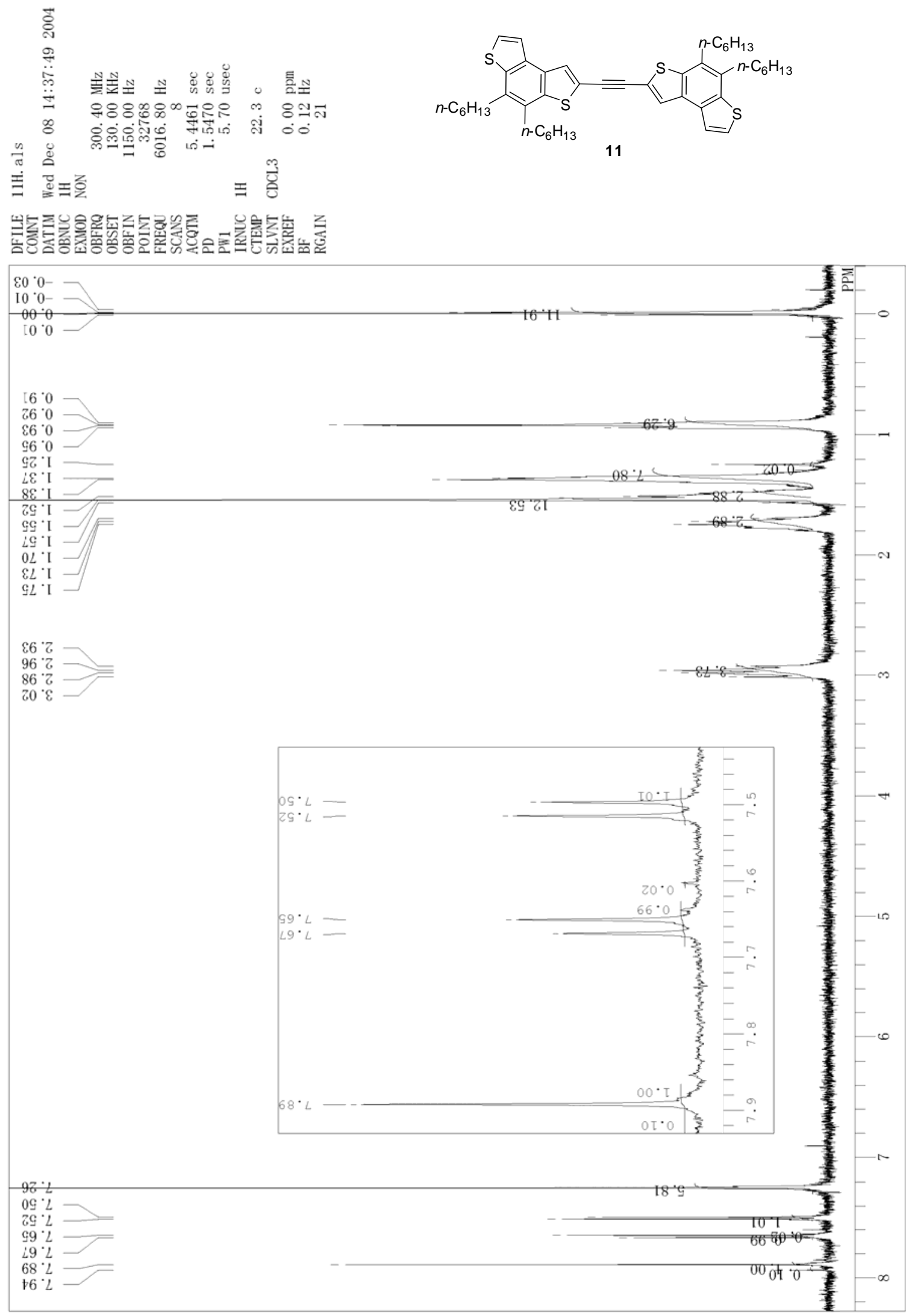




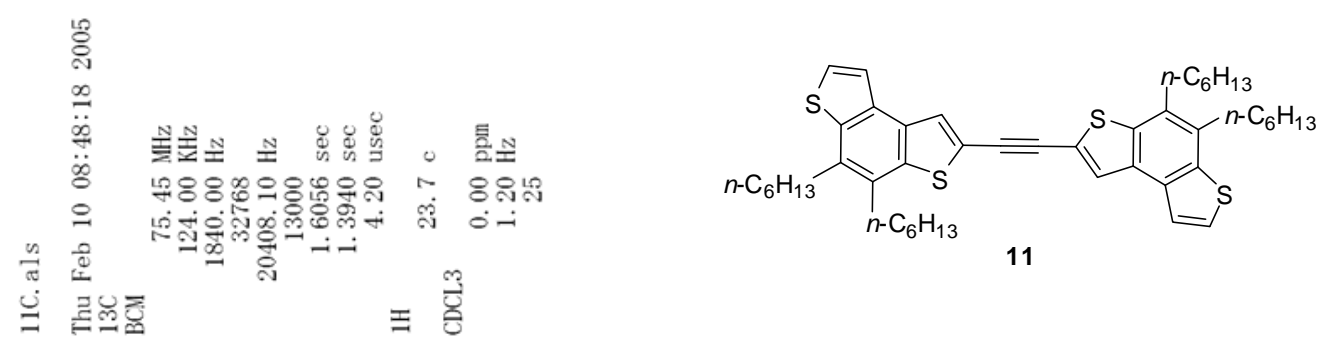

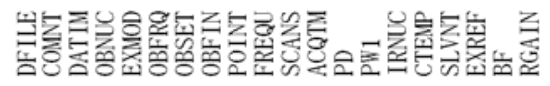

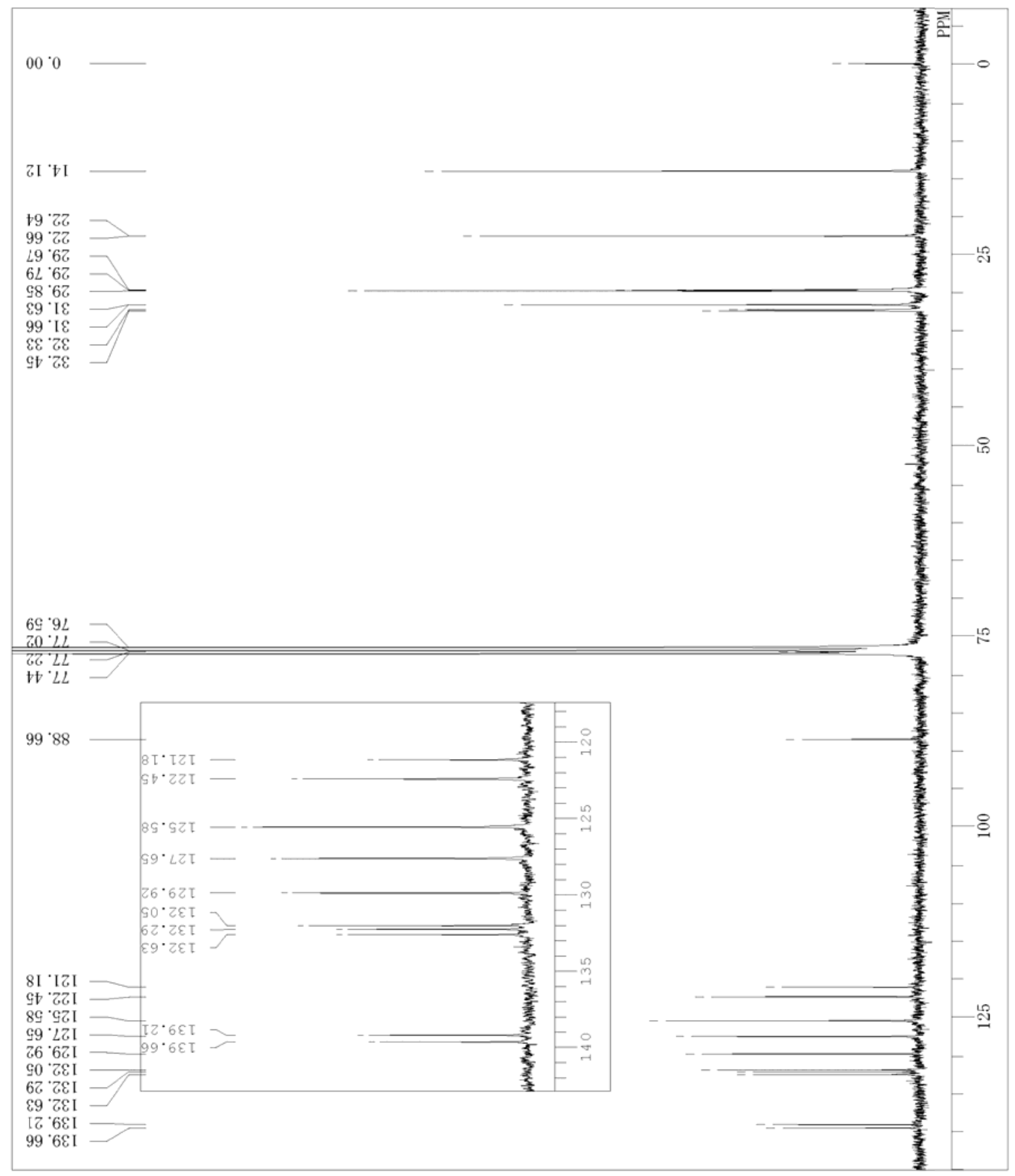

S34 


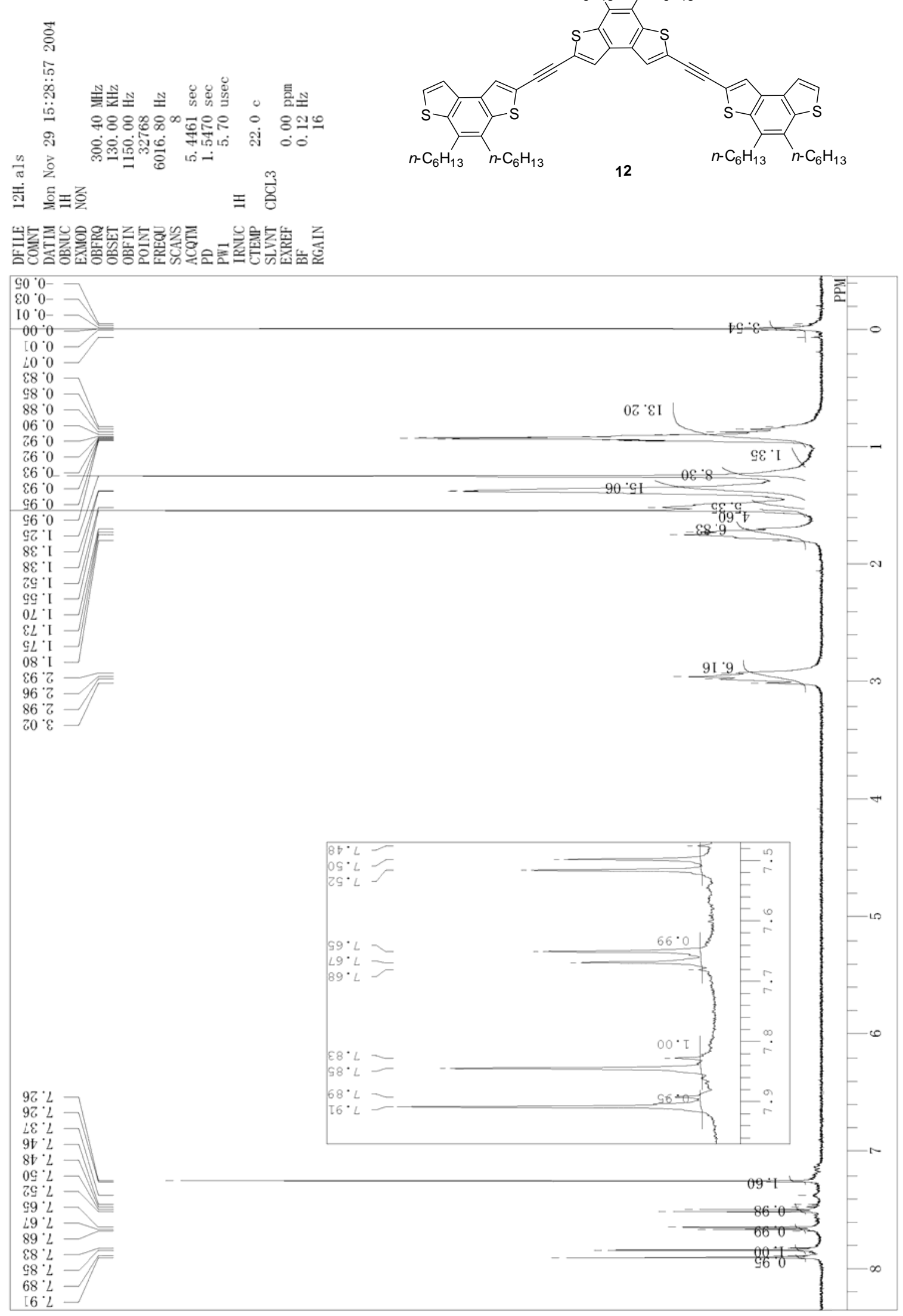




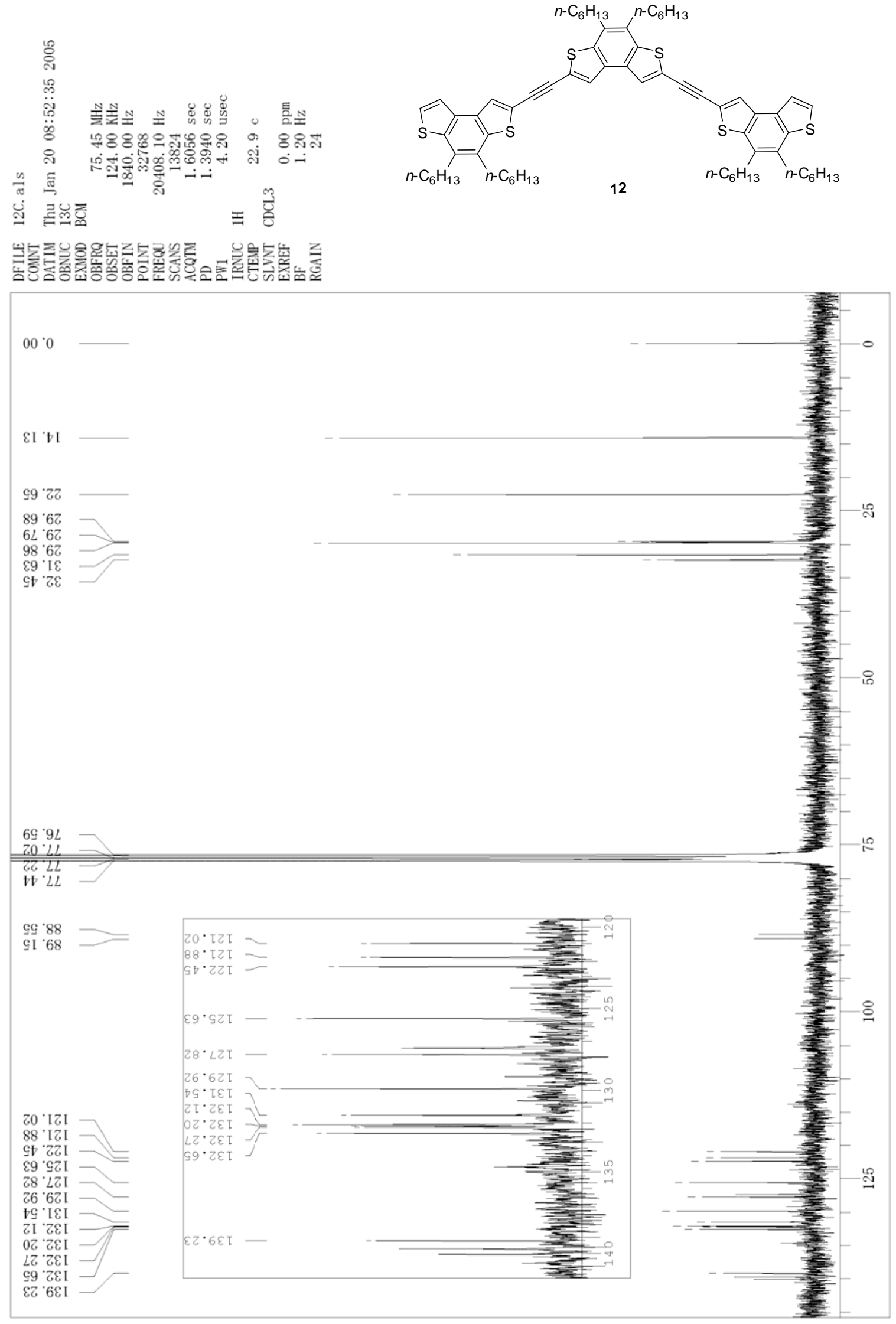




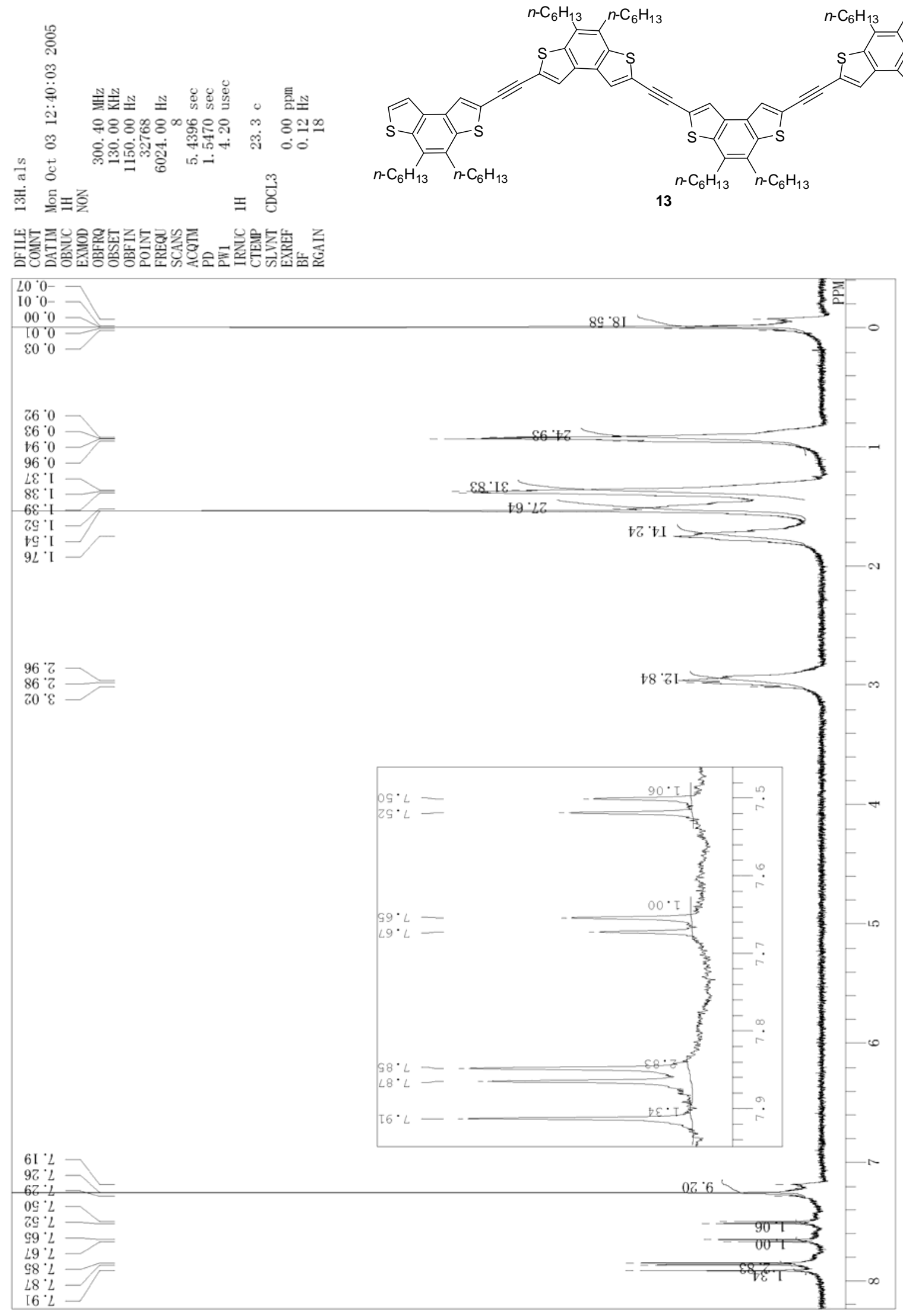



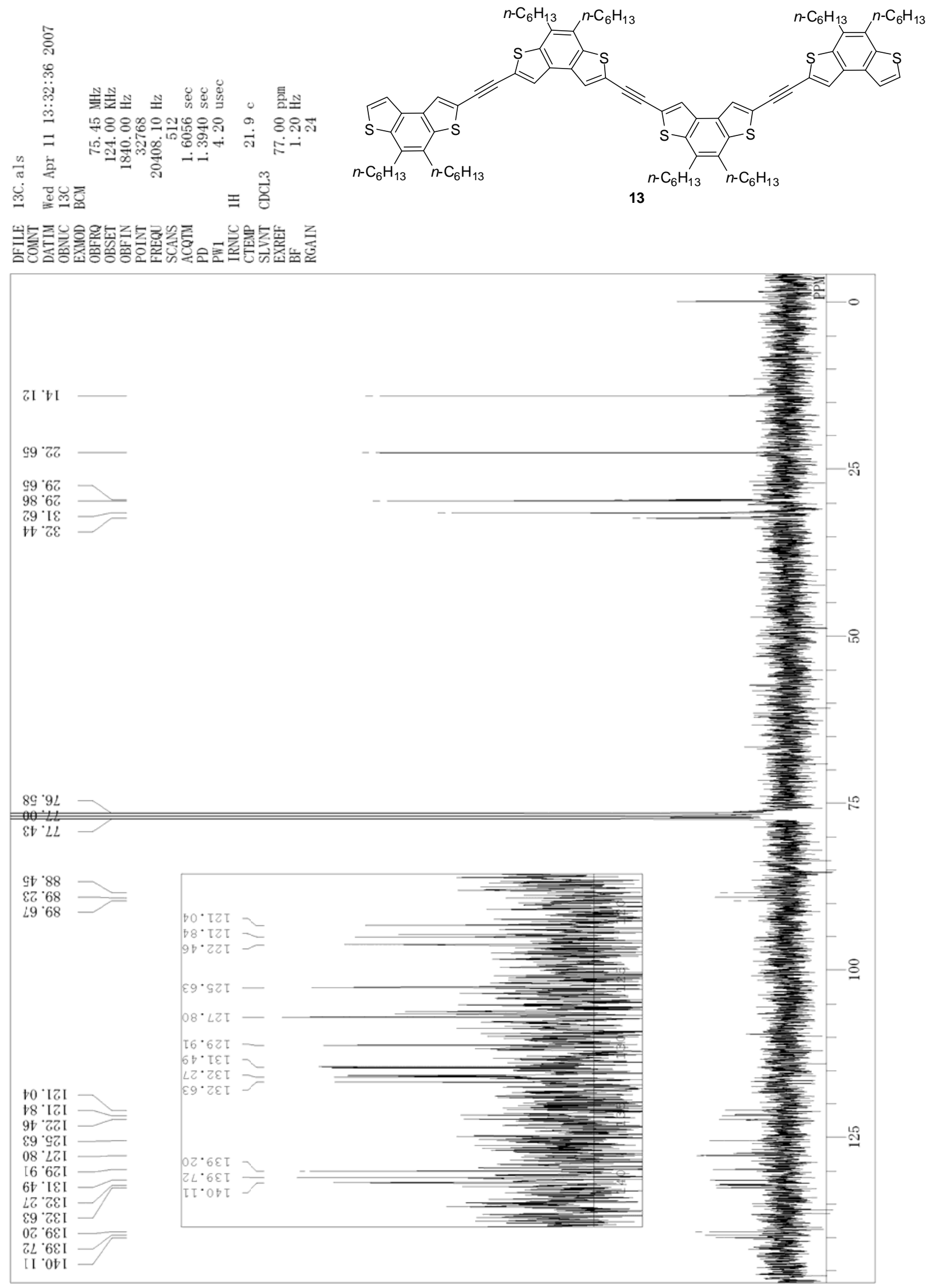


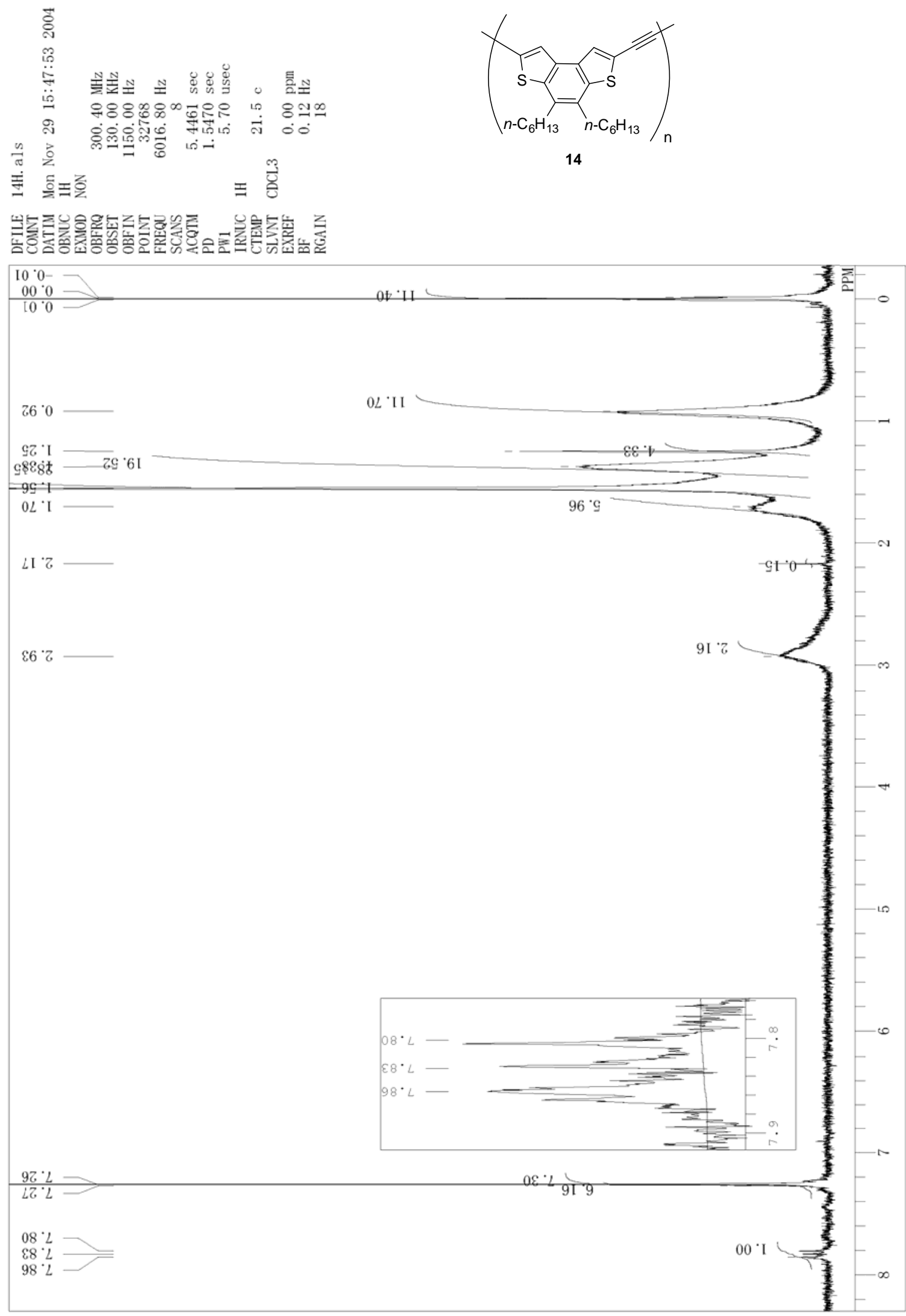



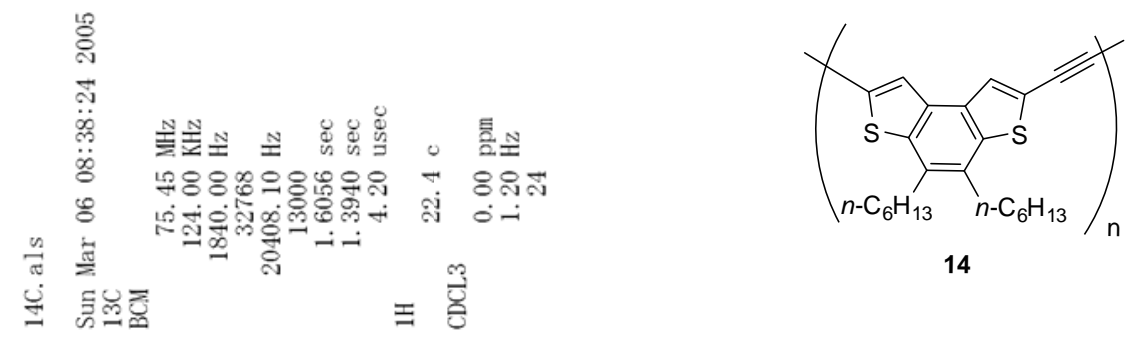

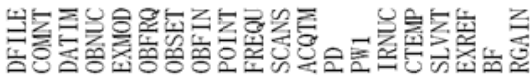

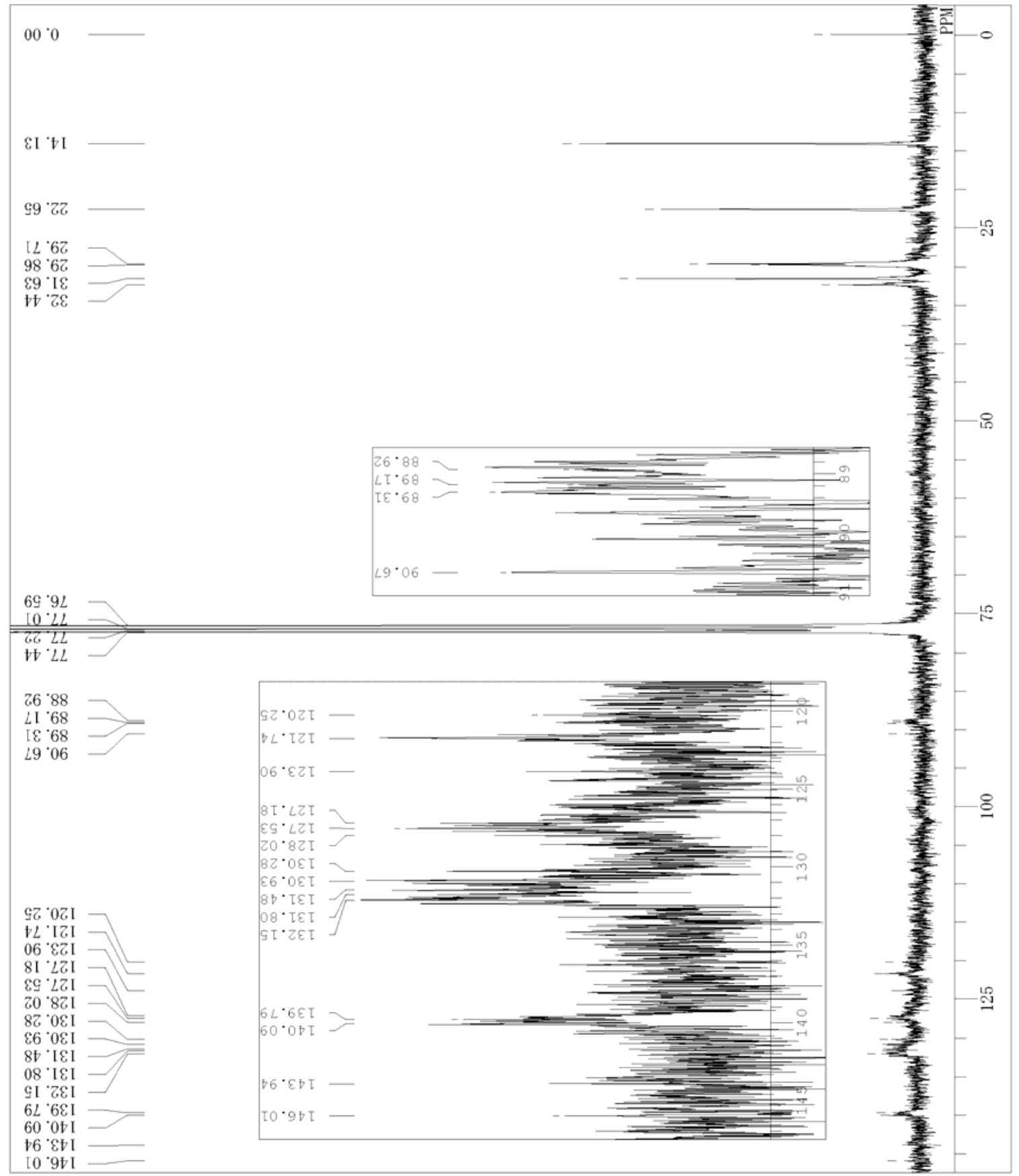




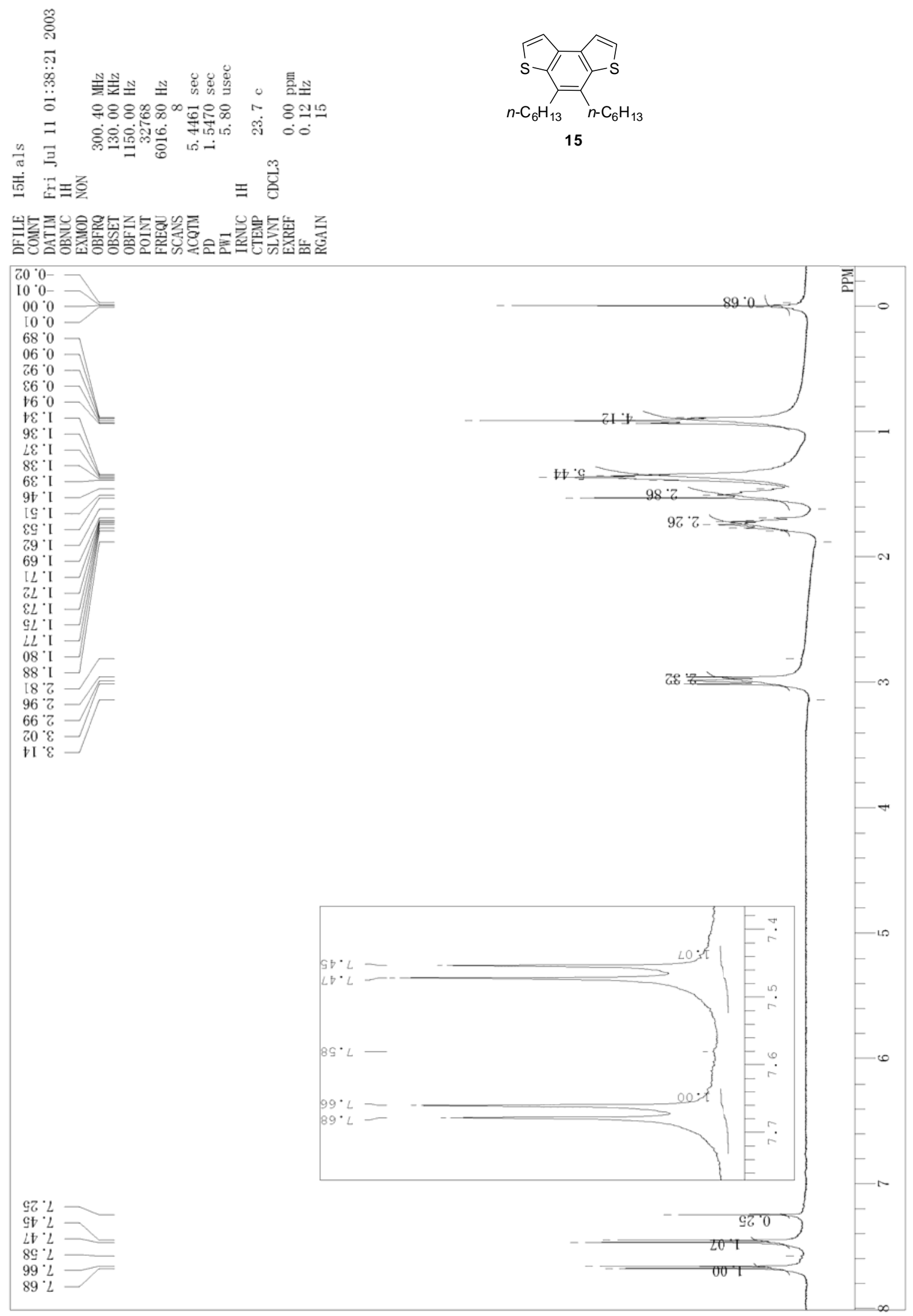




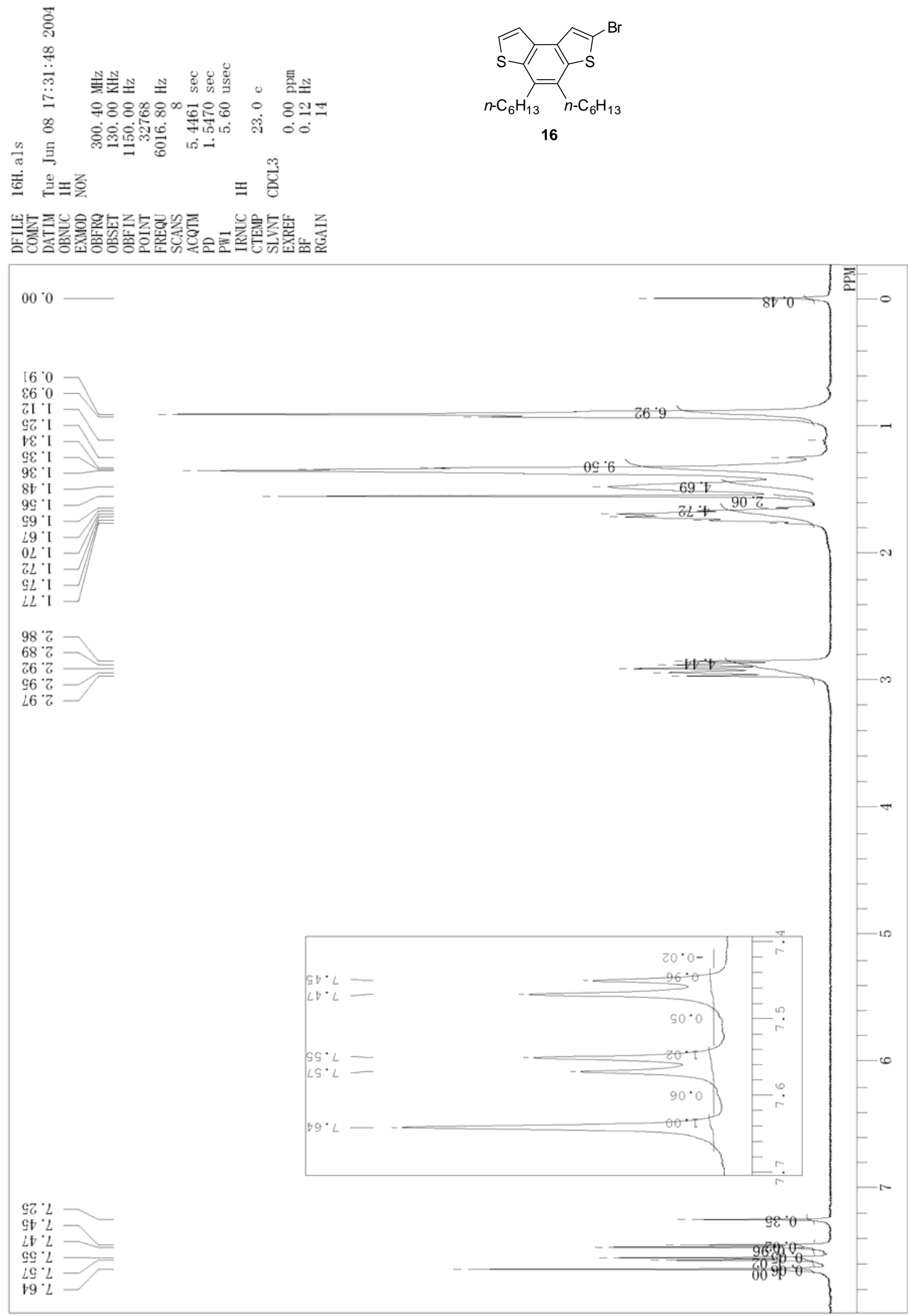




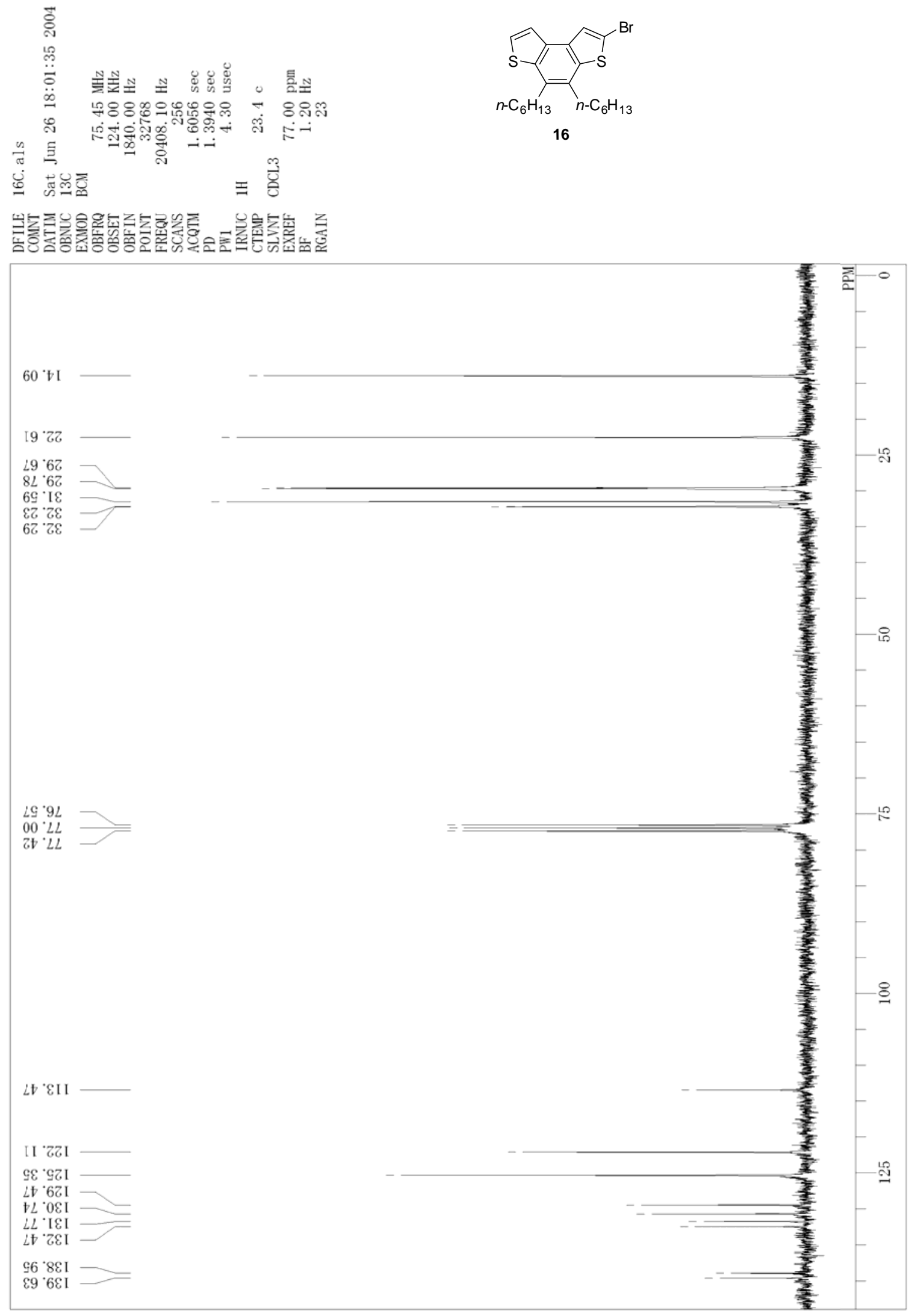




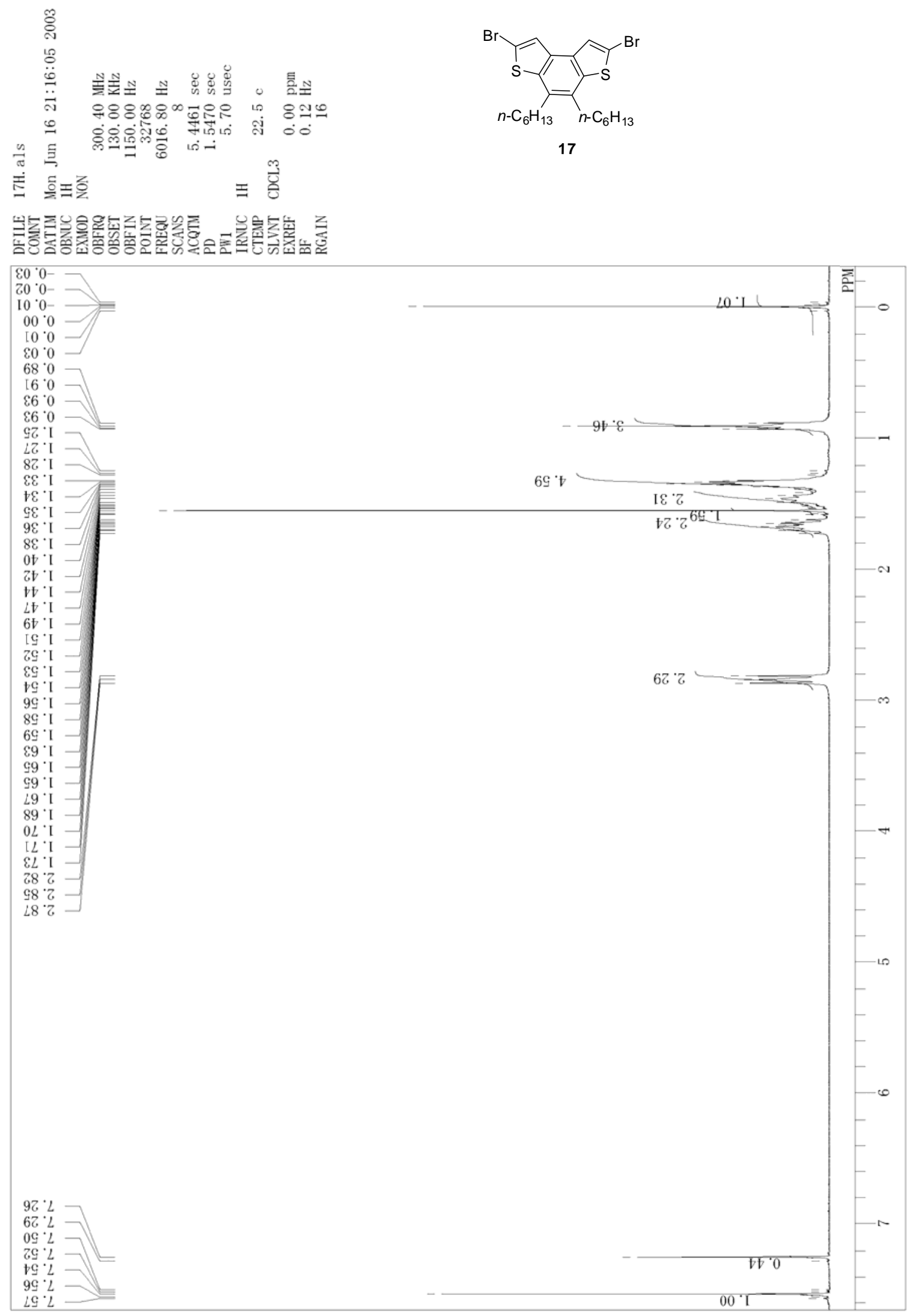




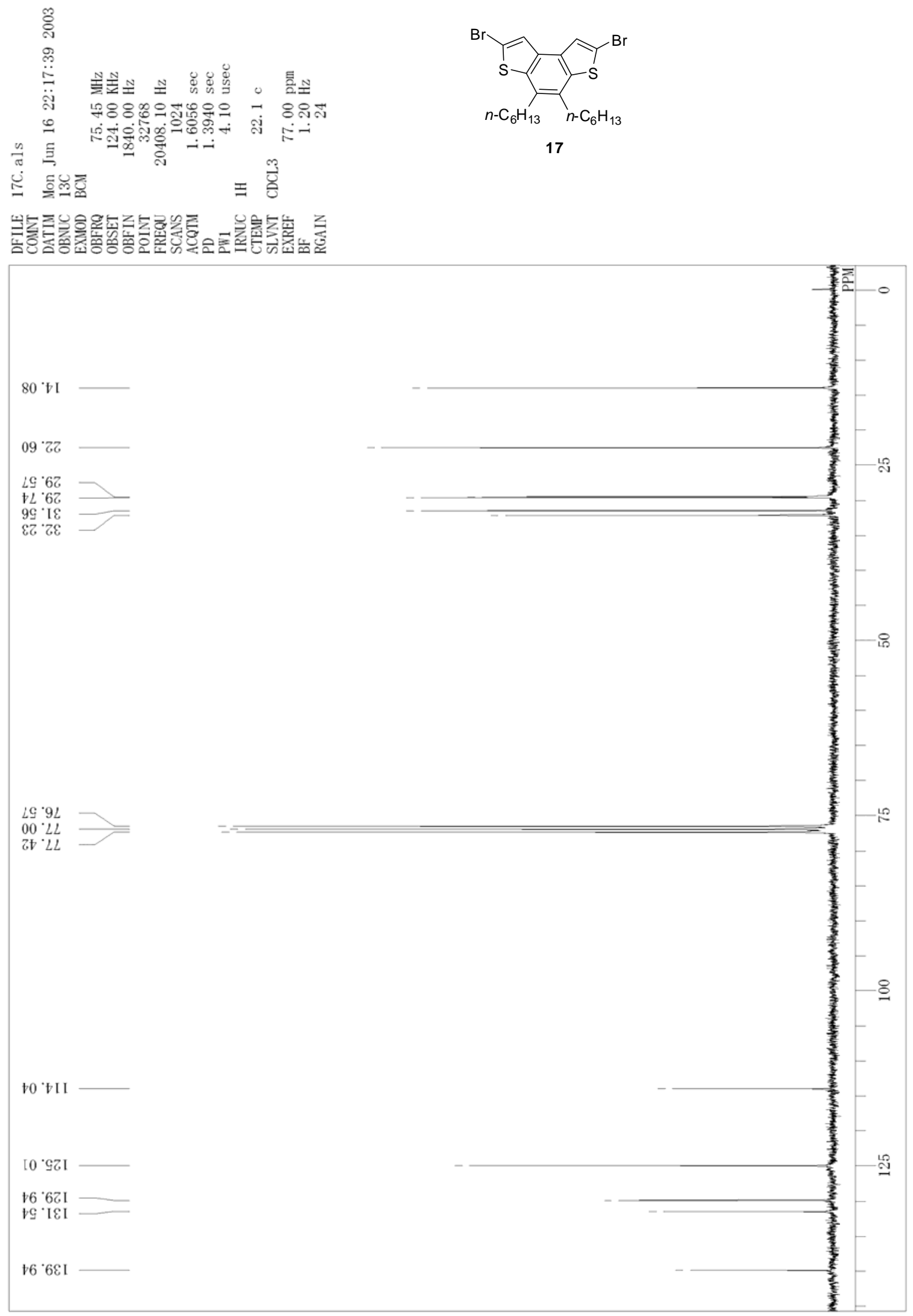




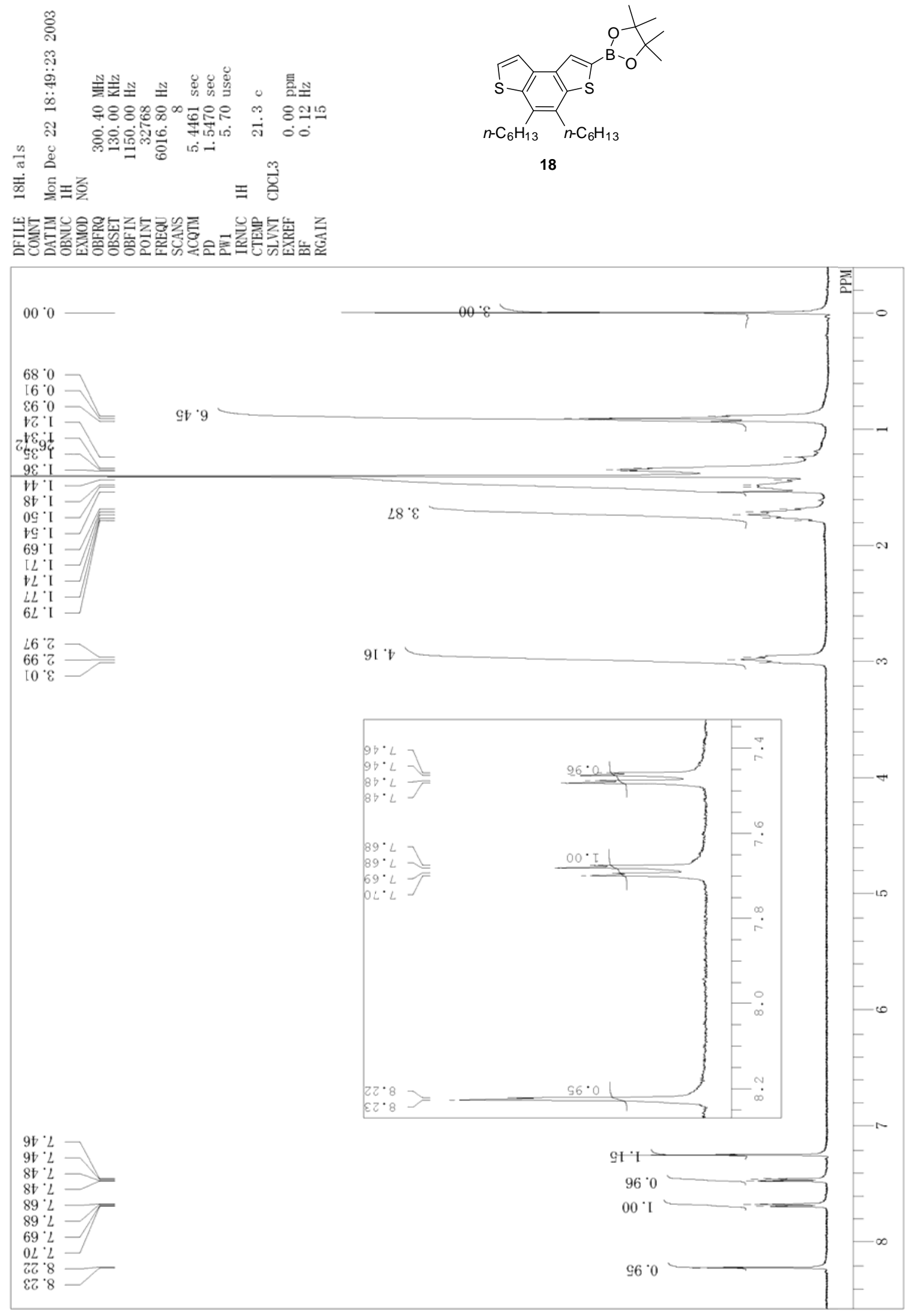



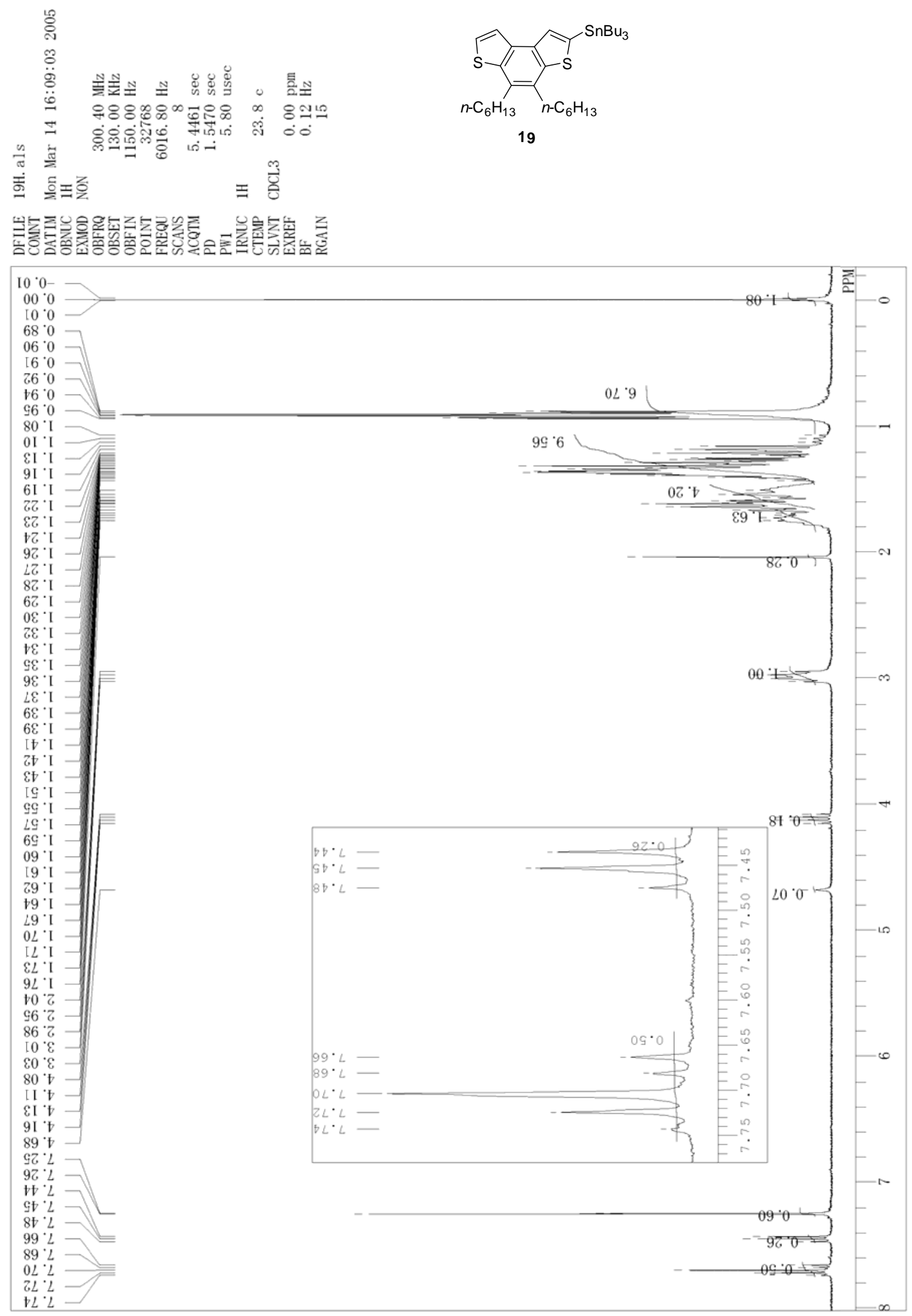

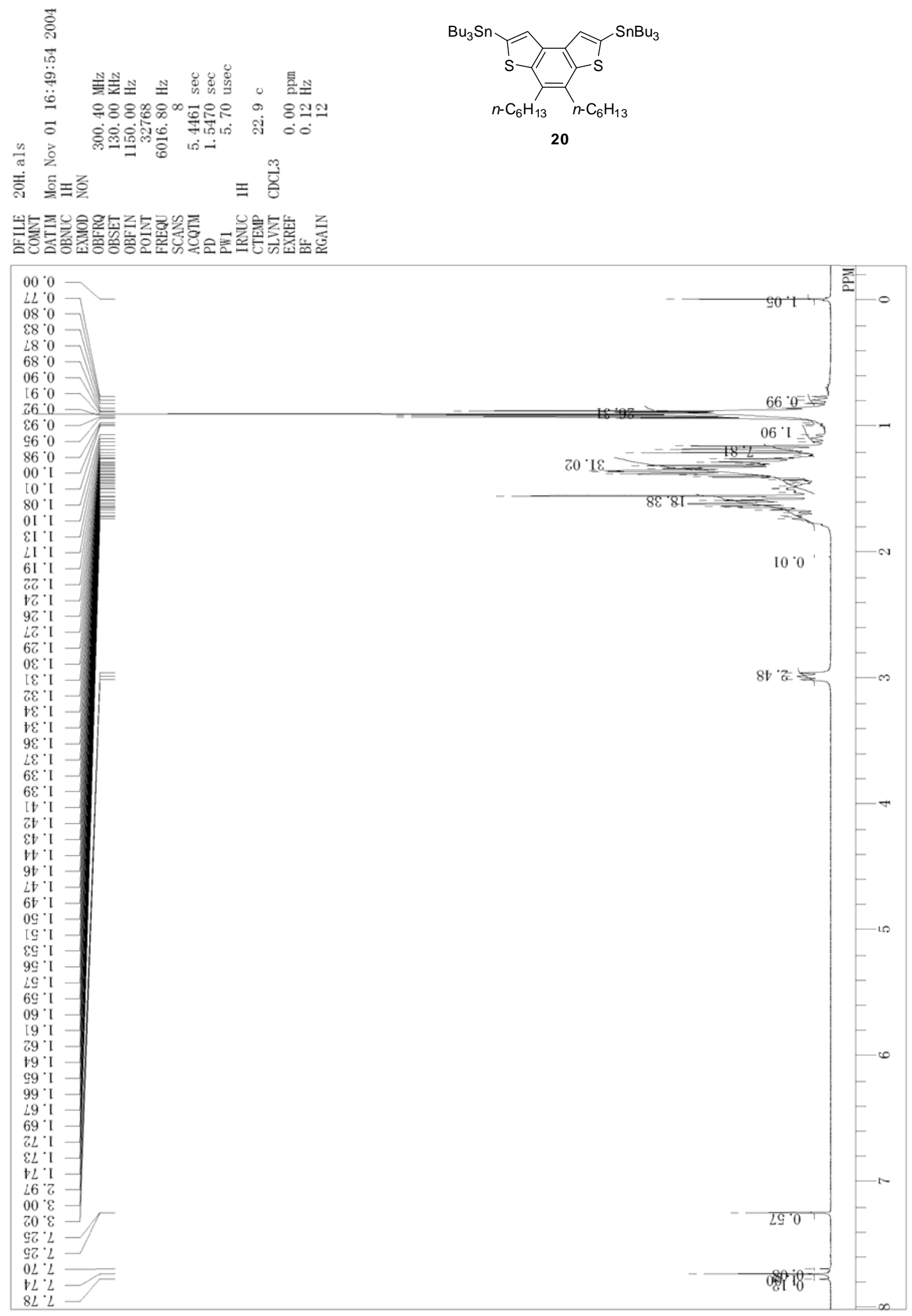


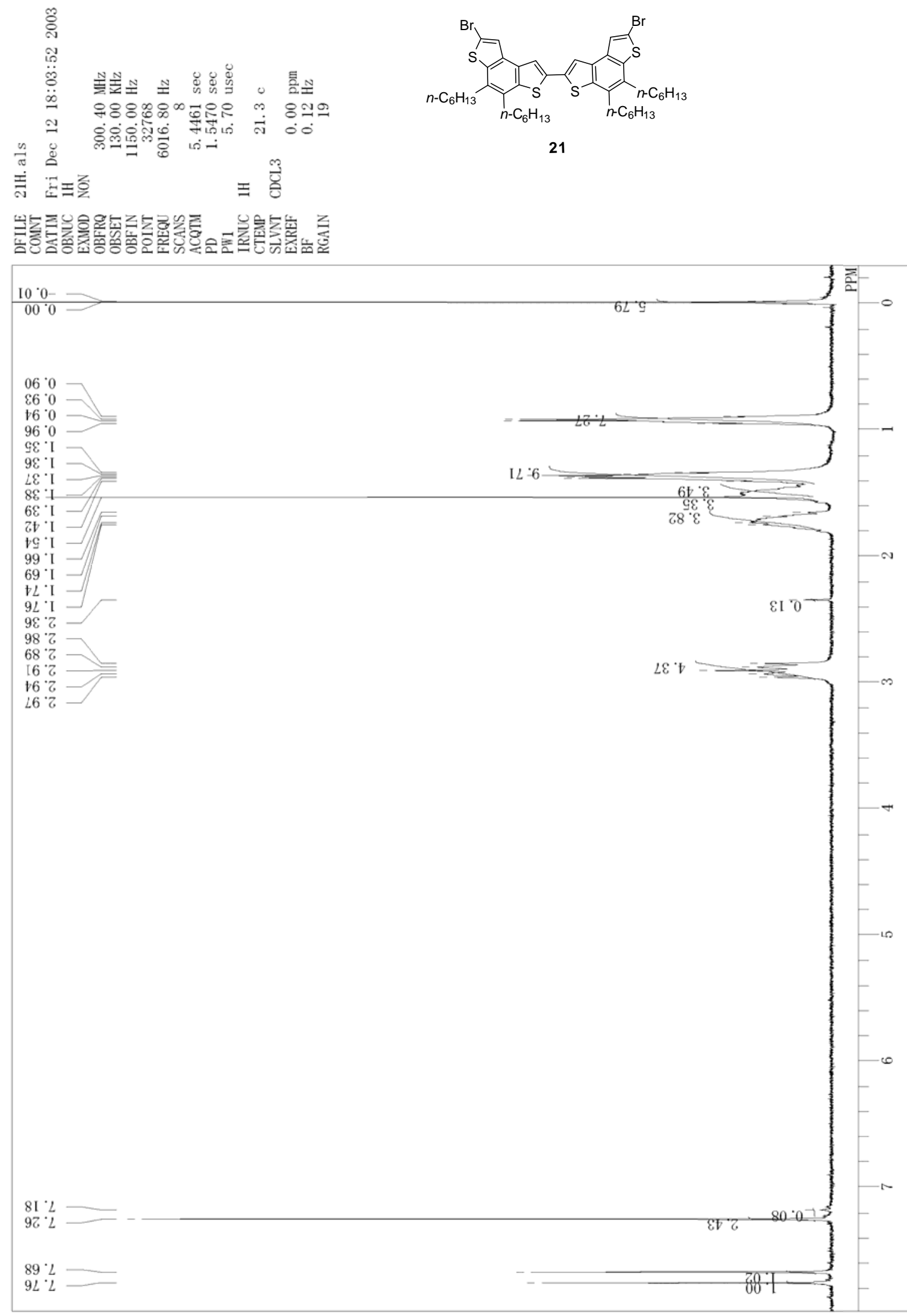




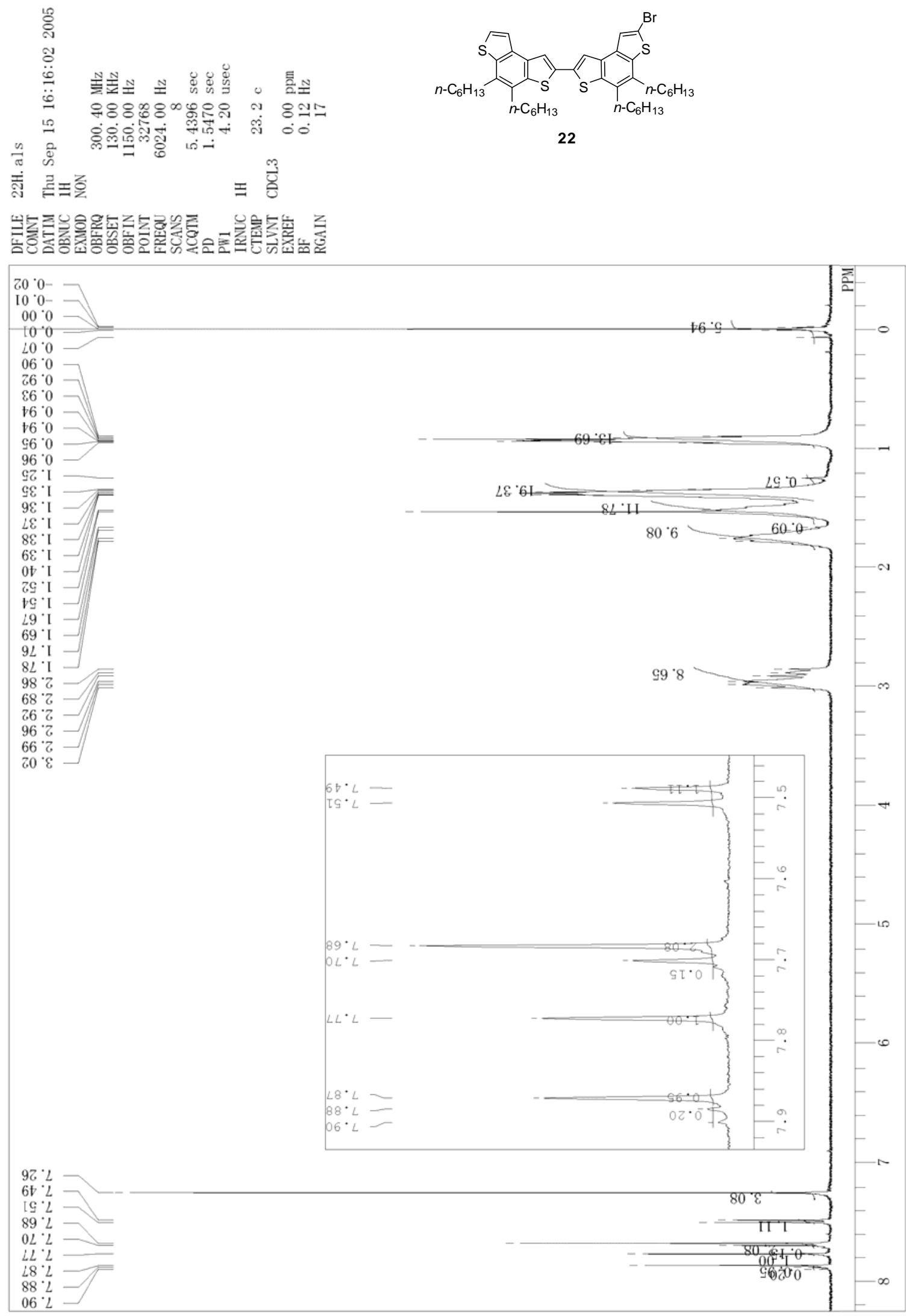




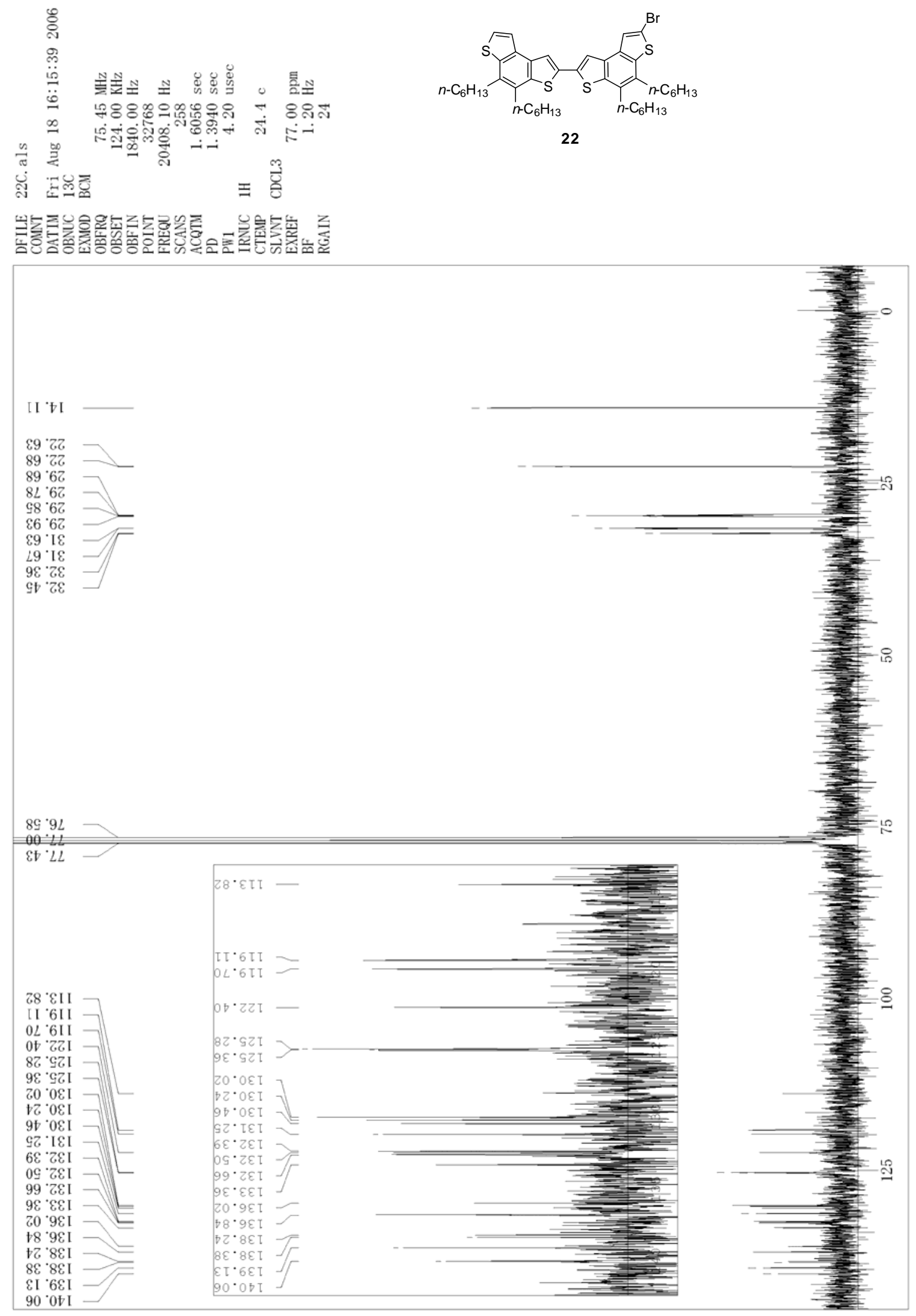




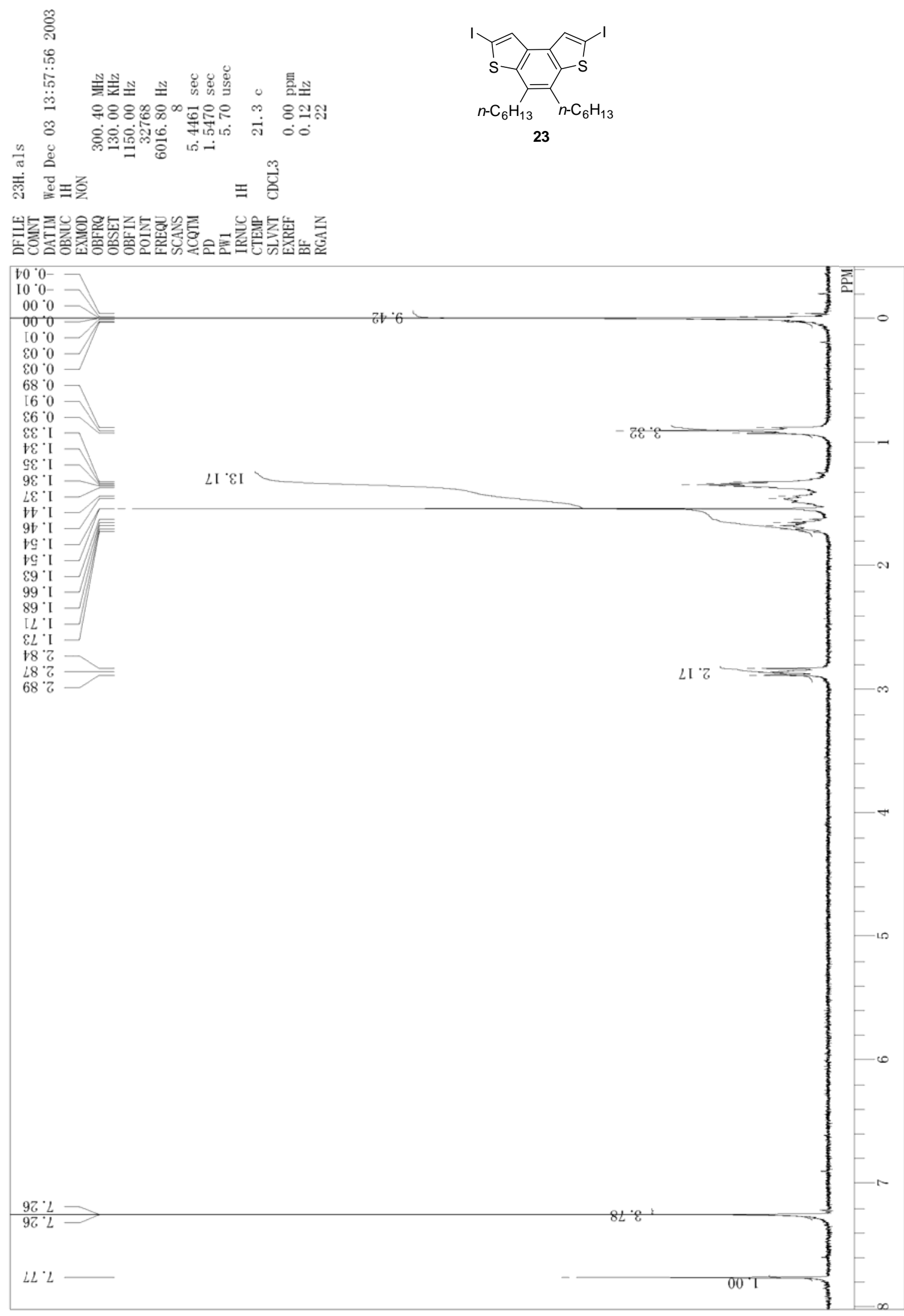




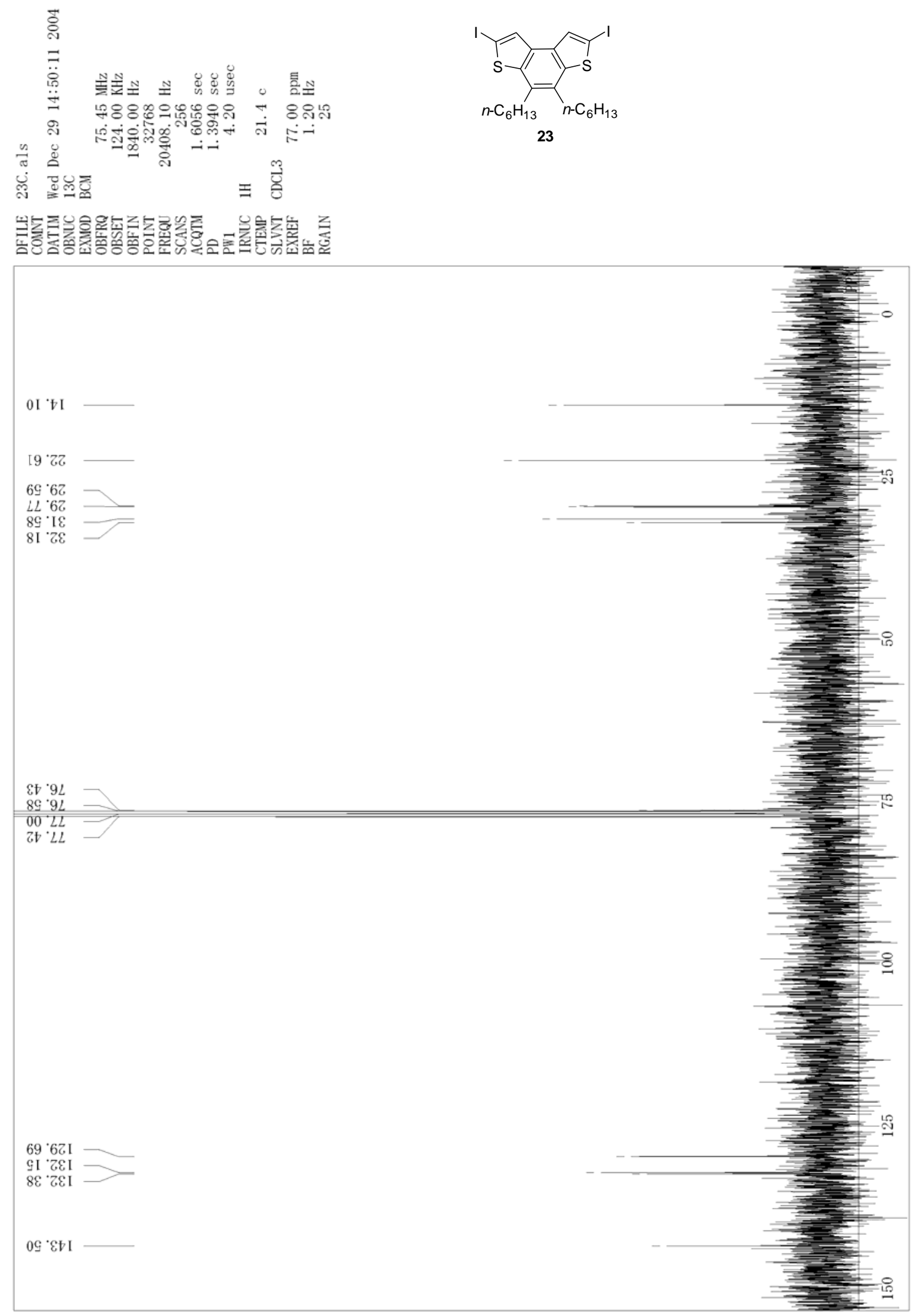




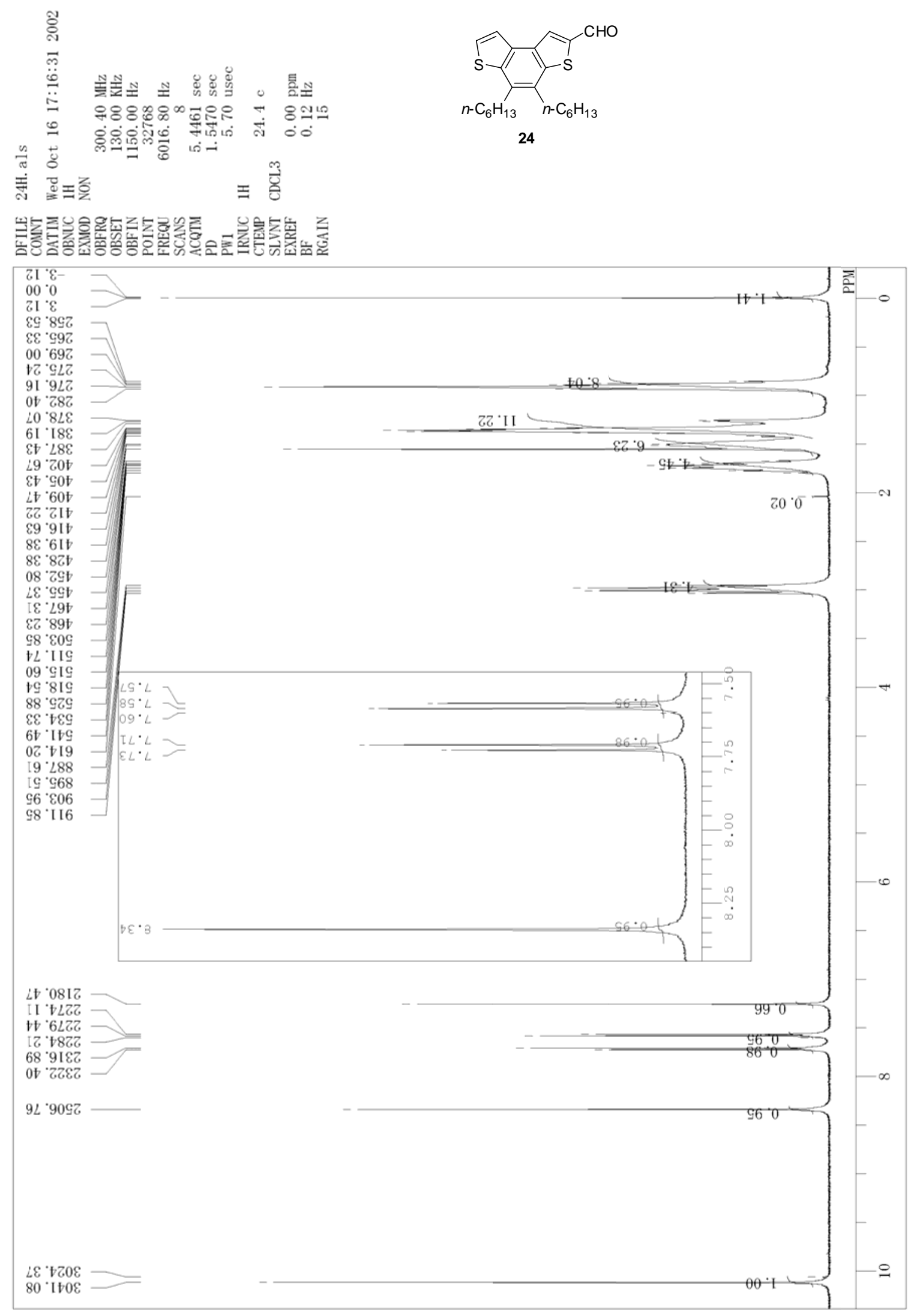




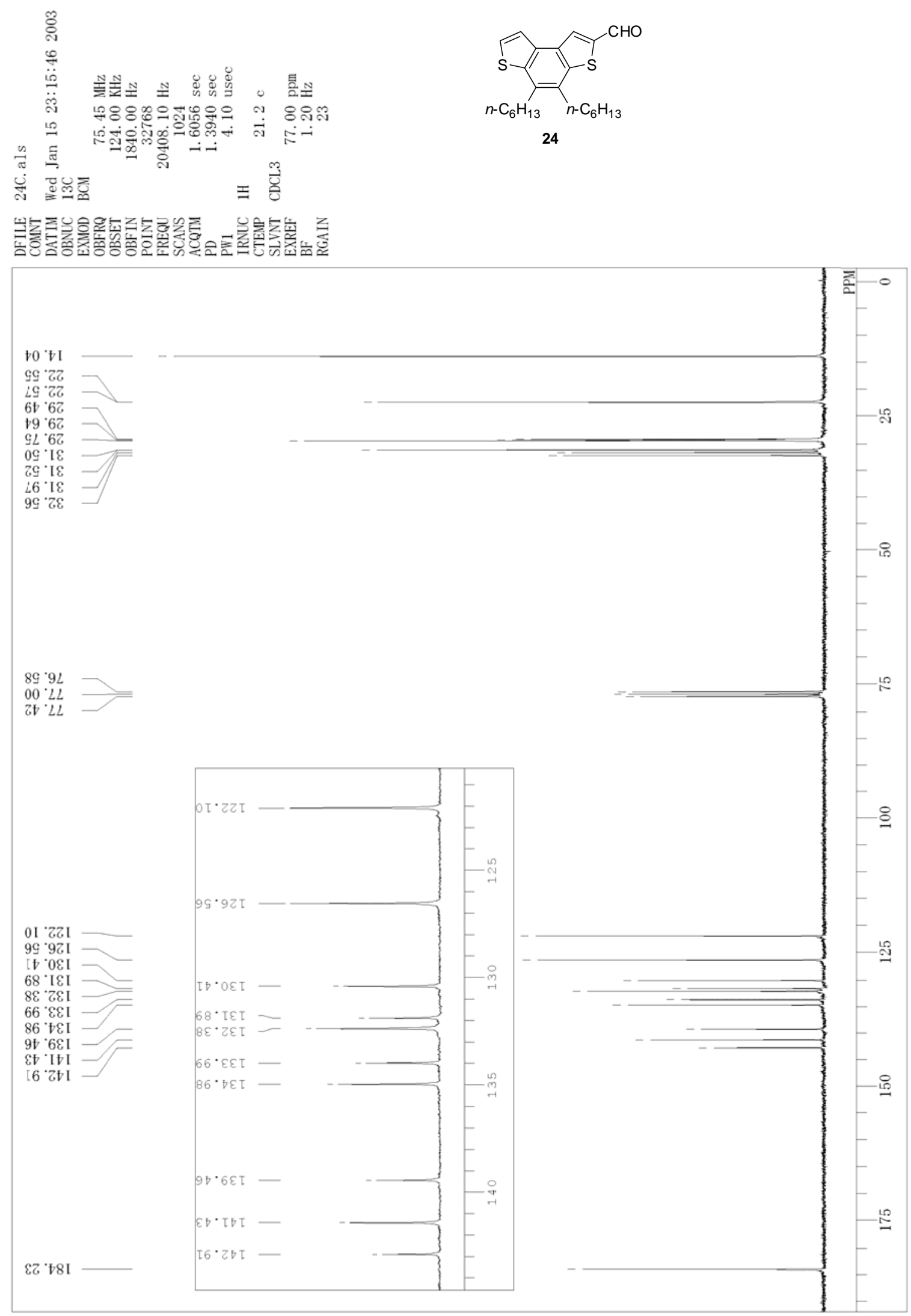




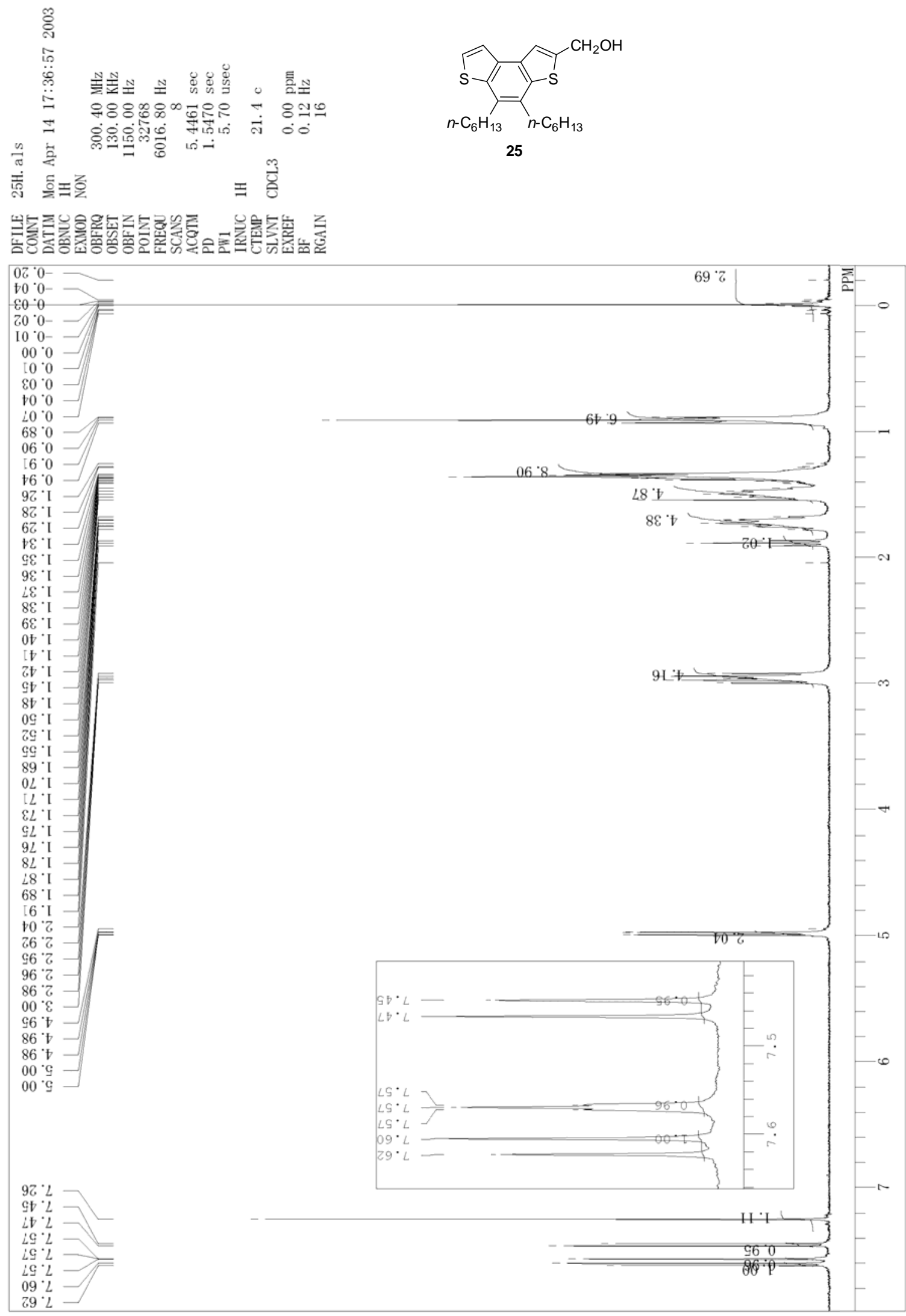




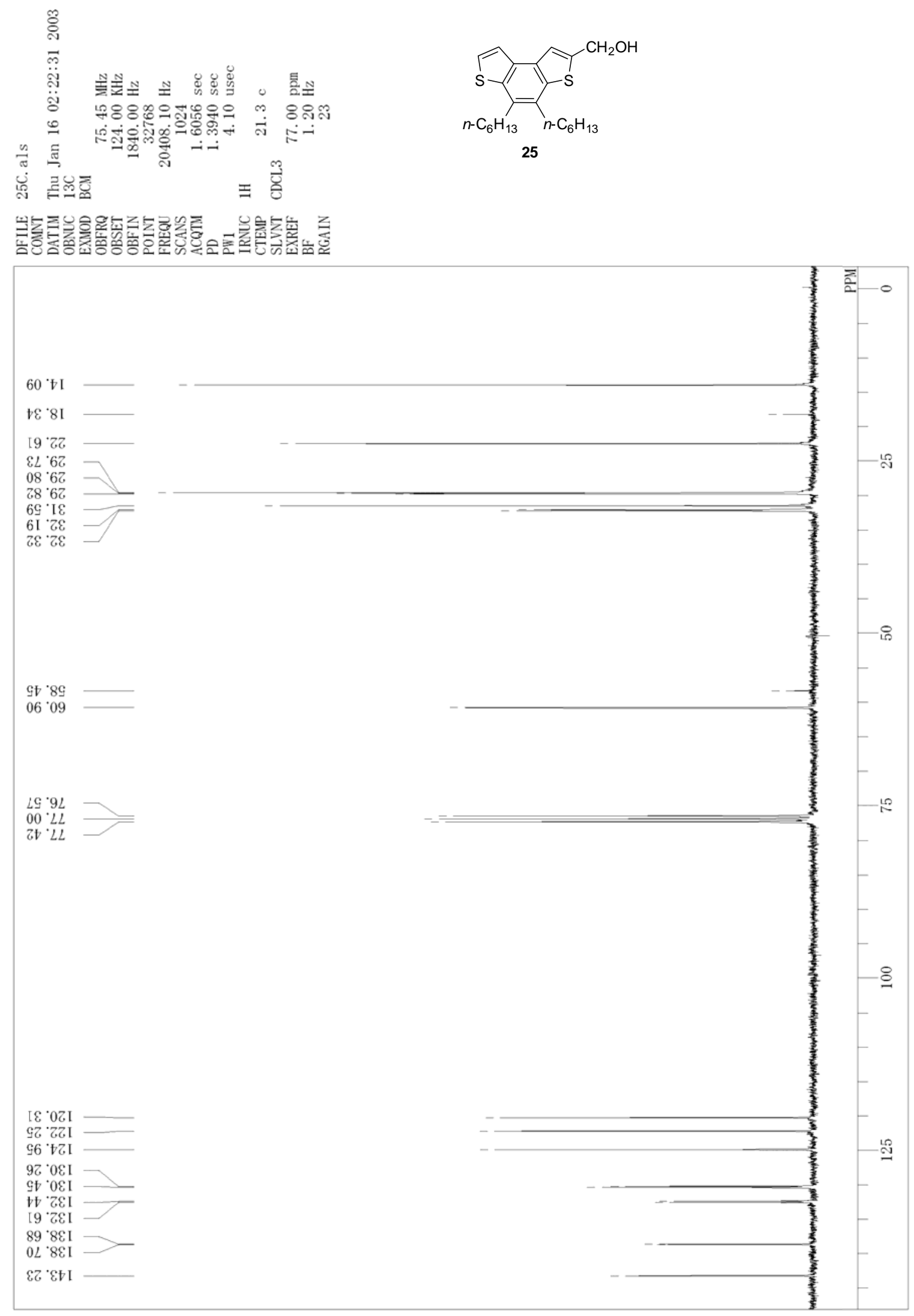




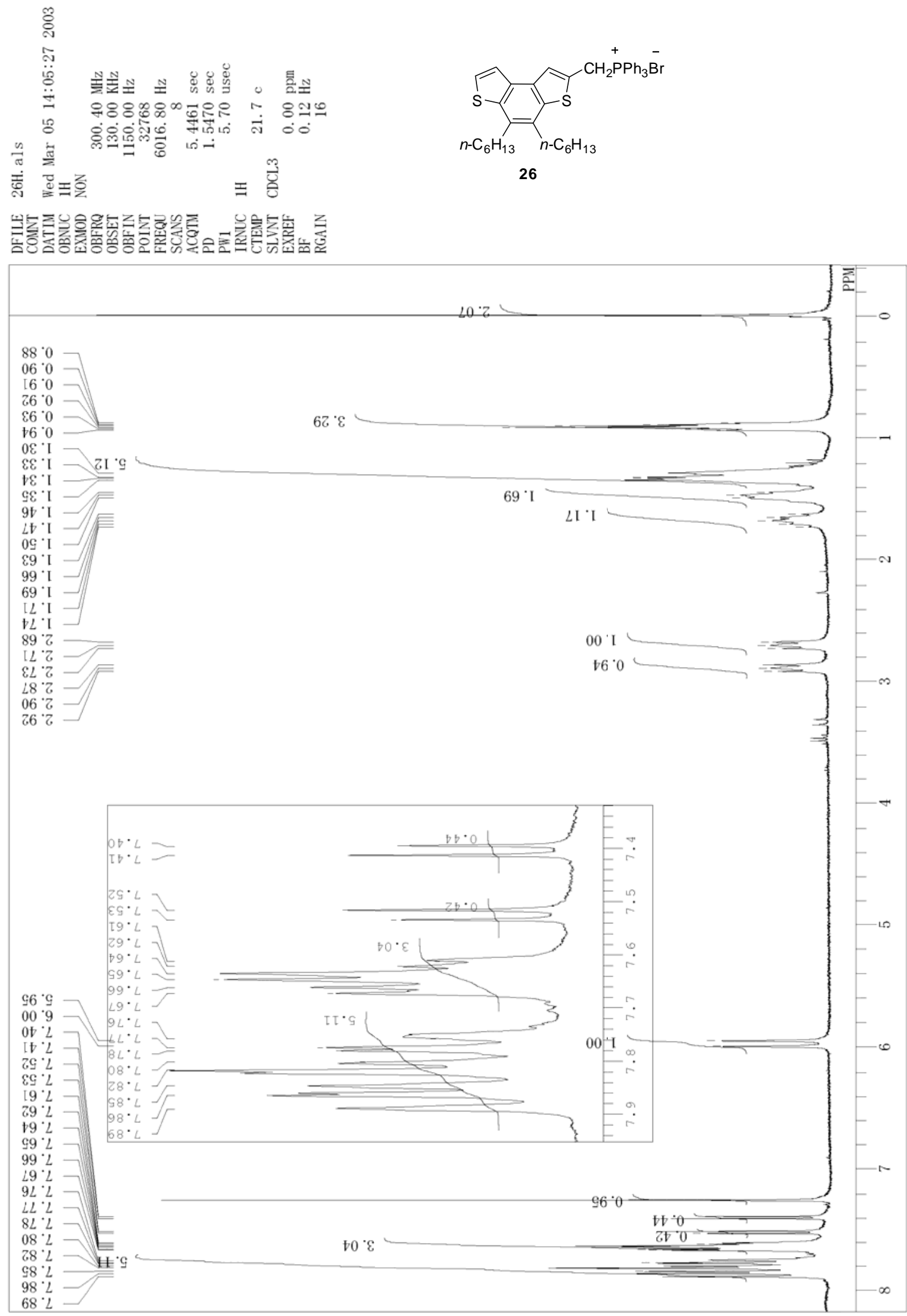




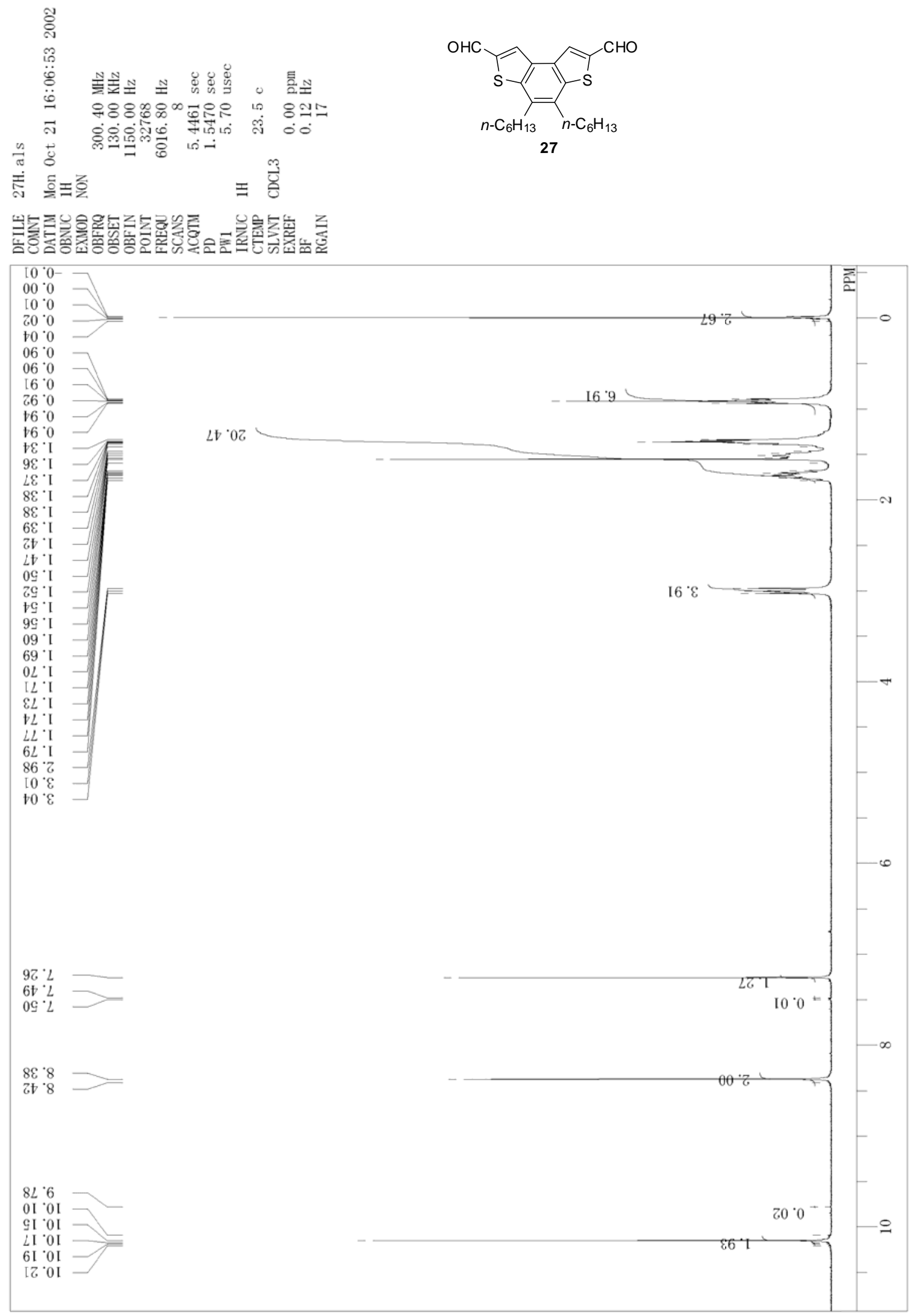




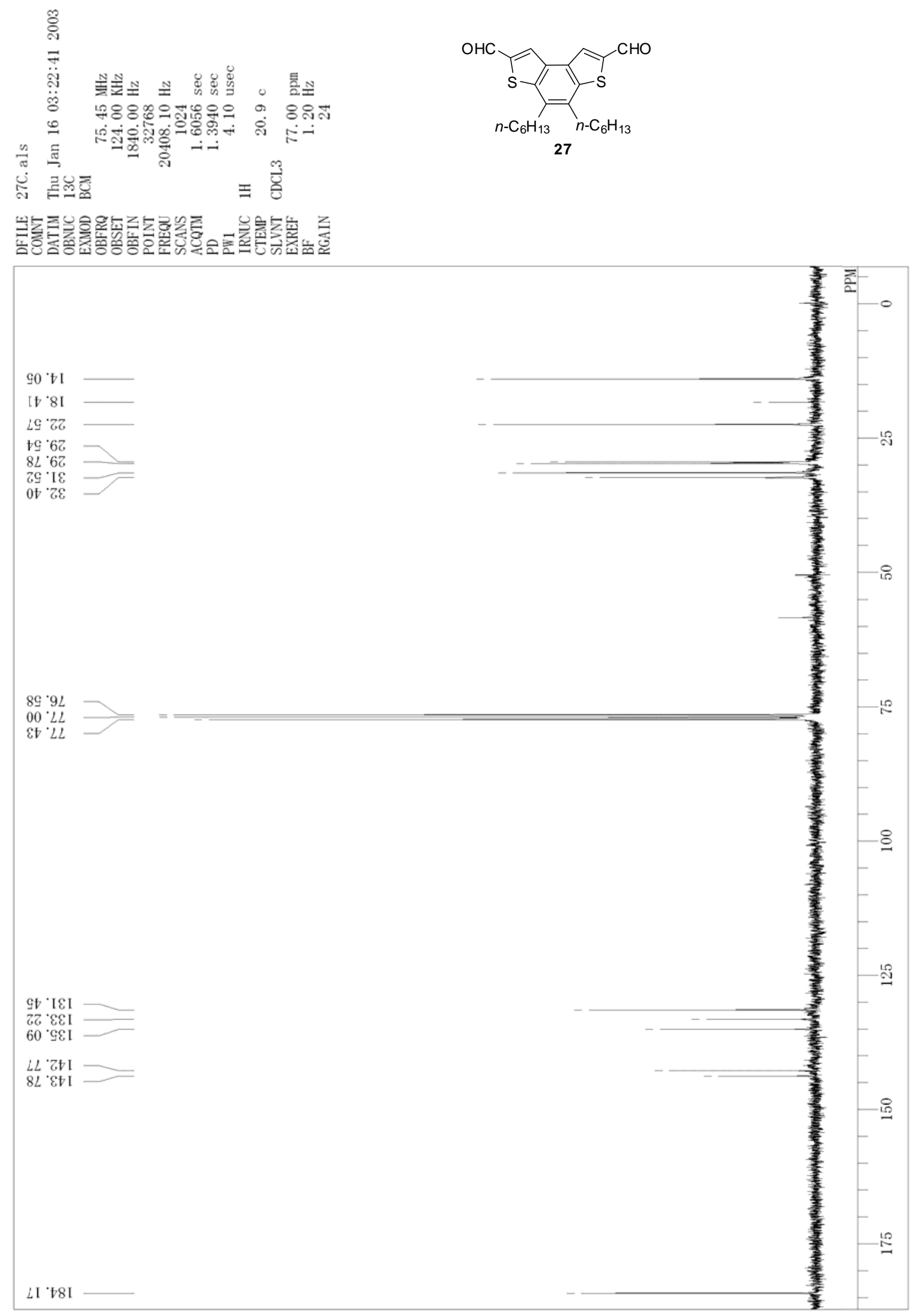



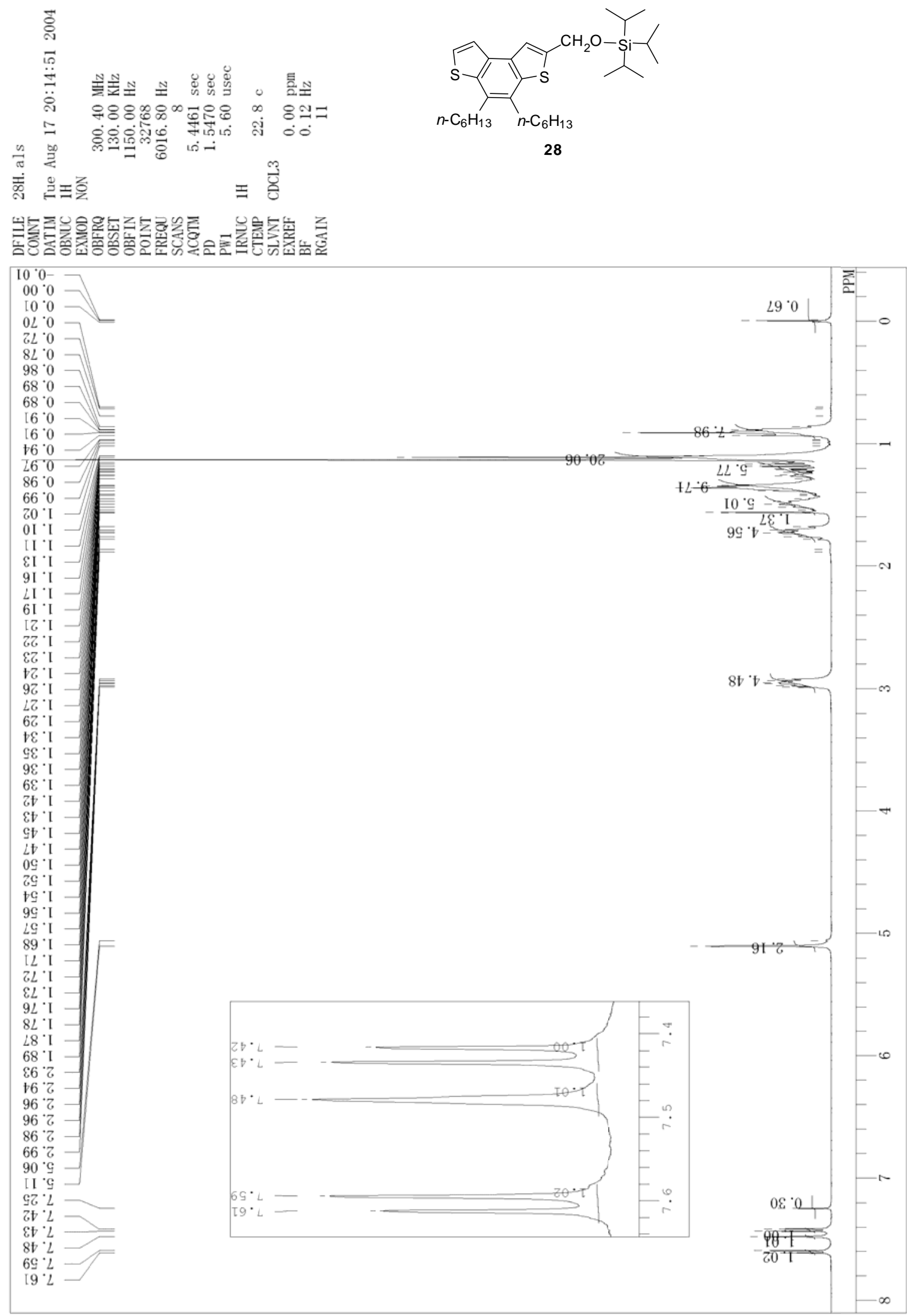


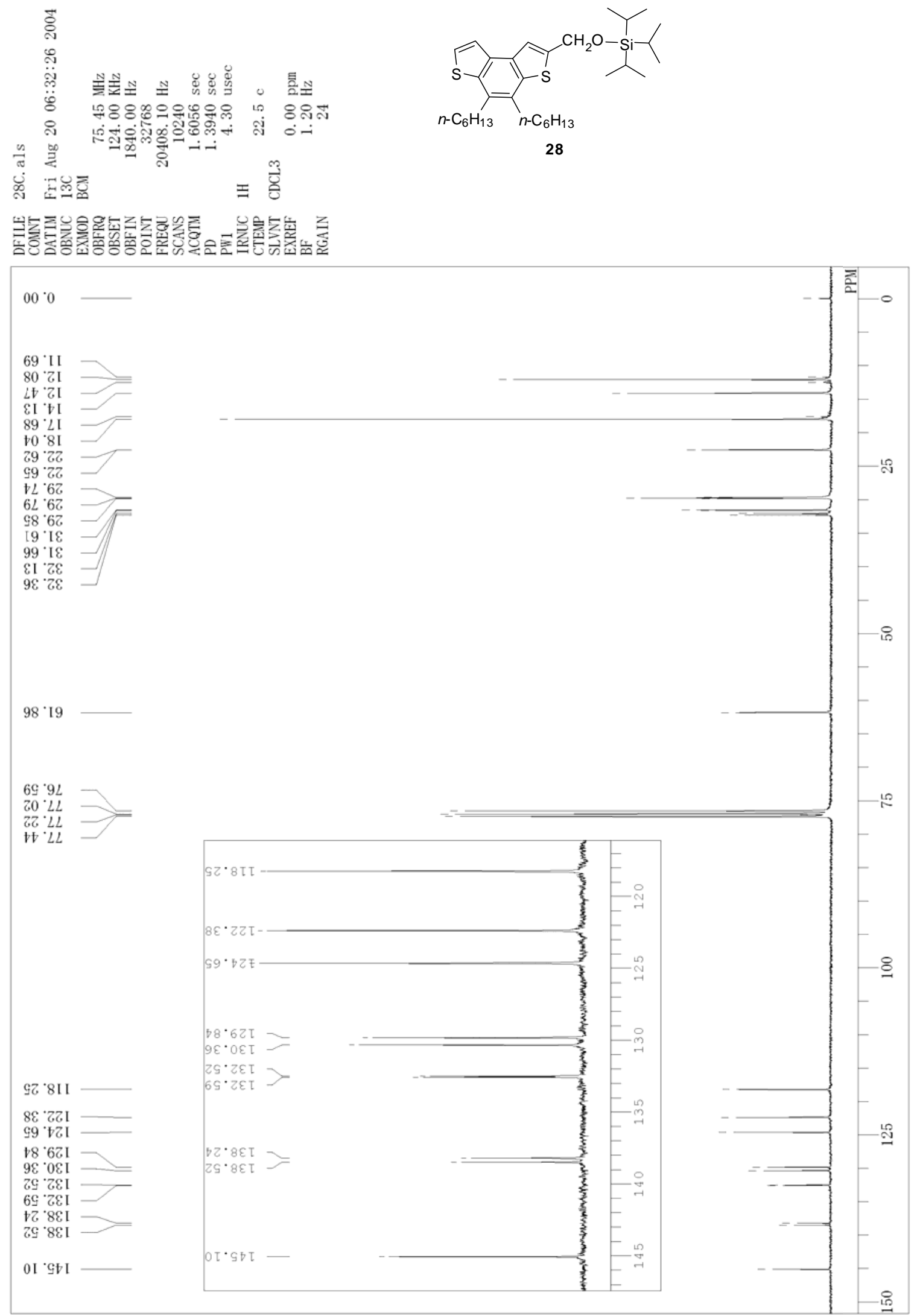


बे

11 เ

实苧

$=\frac{1}{9}$

蛙方

을

홓ㅎㅀ를

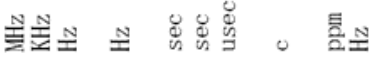

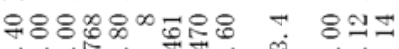

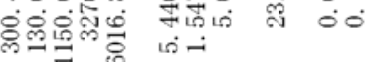

$\equiv \stackrel{m}{\overrightarrow{8}}$

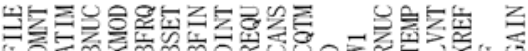

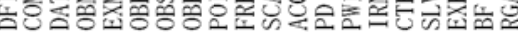

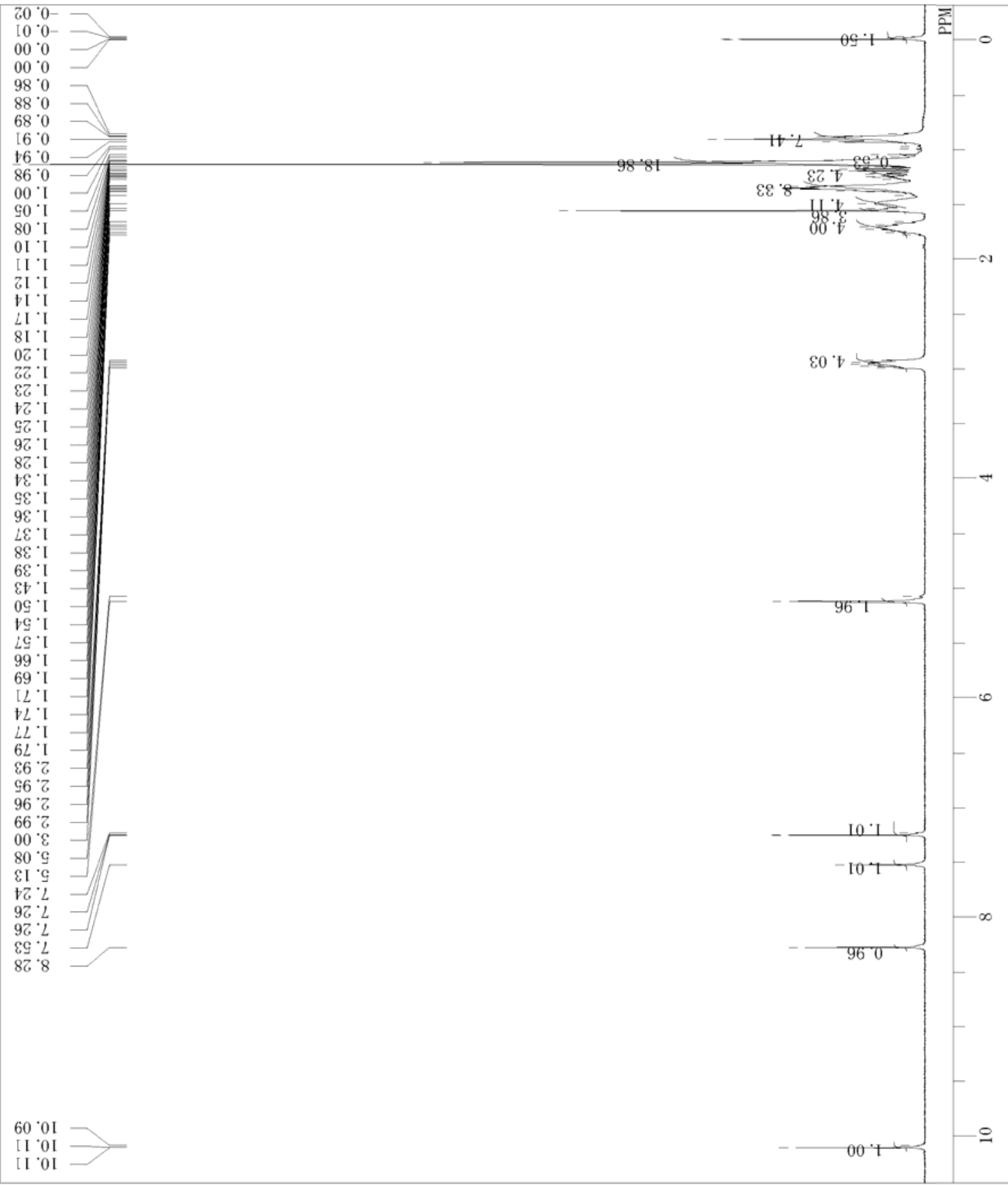




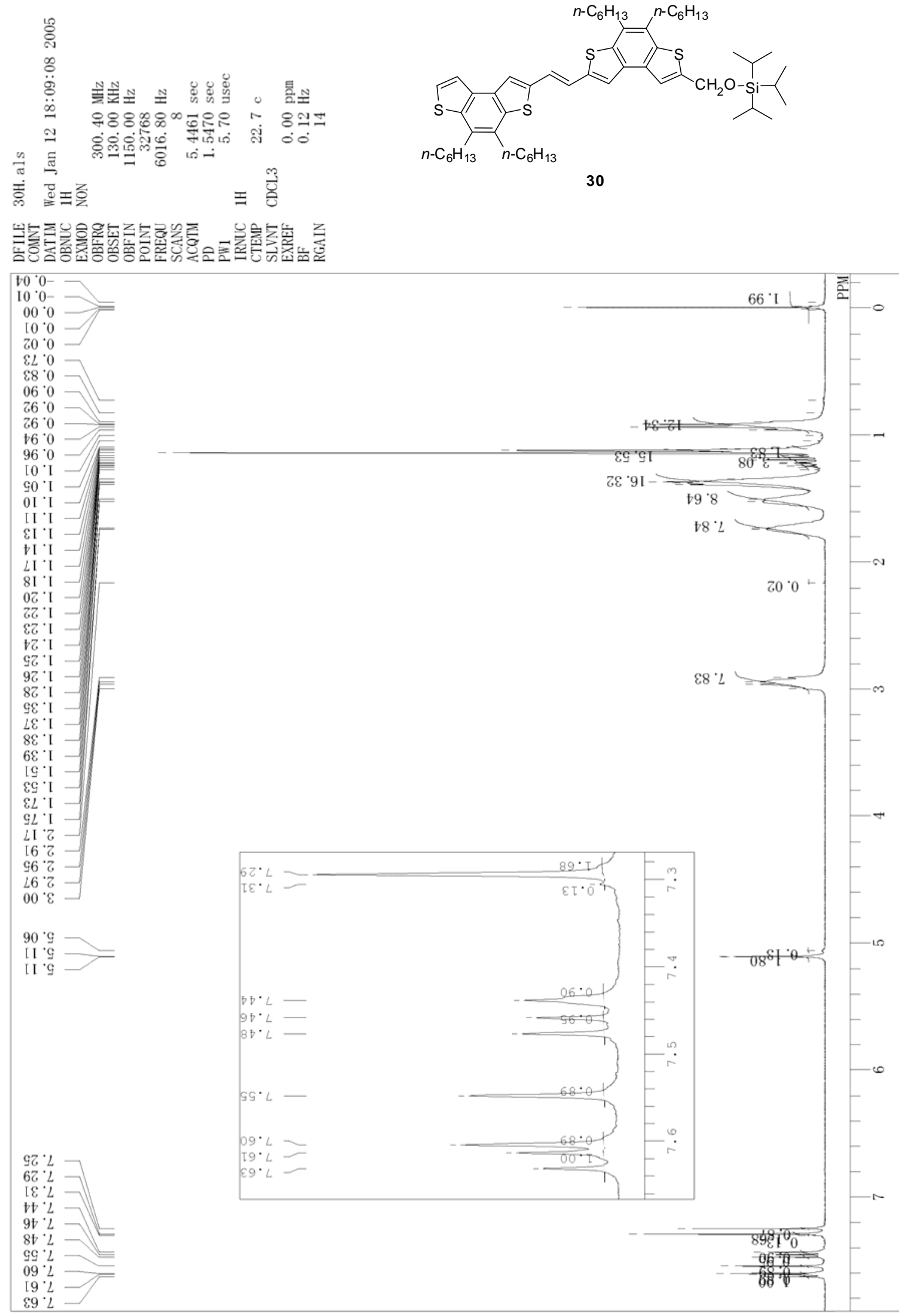




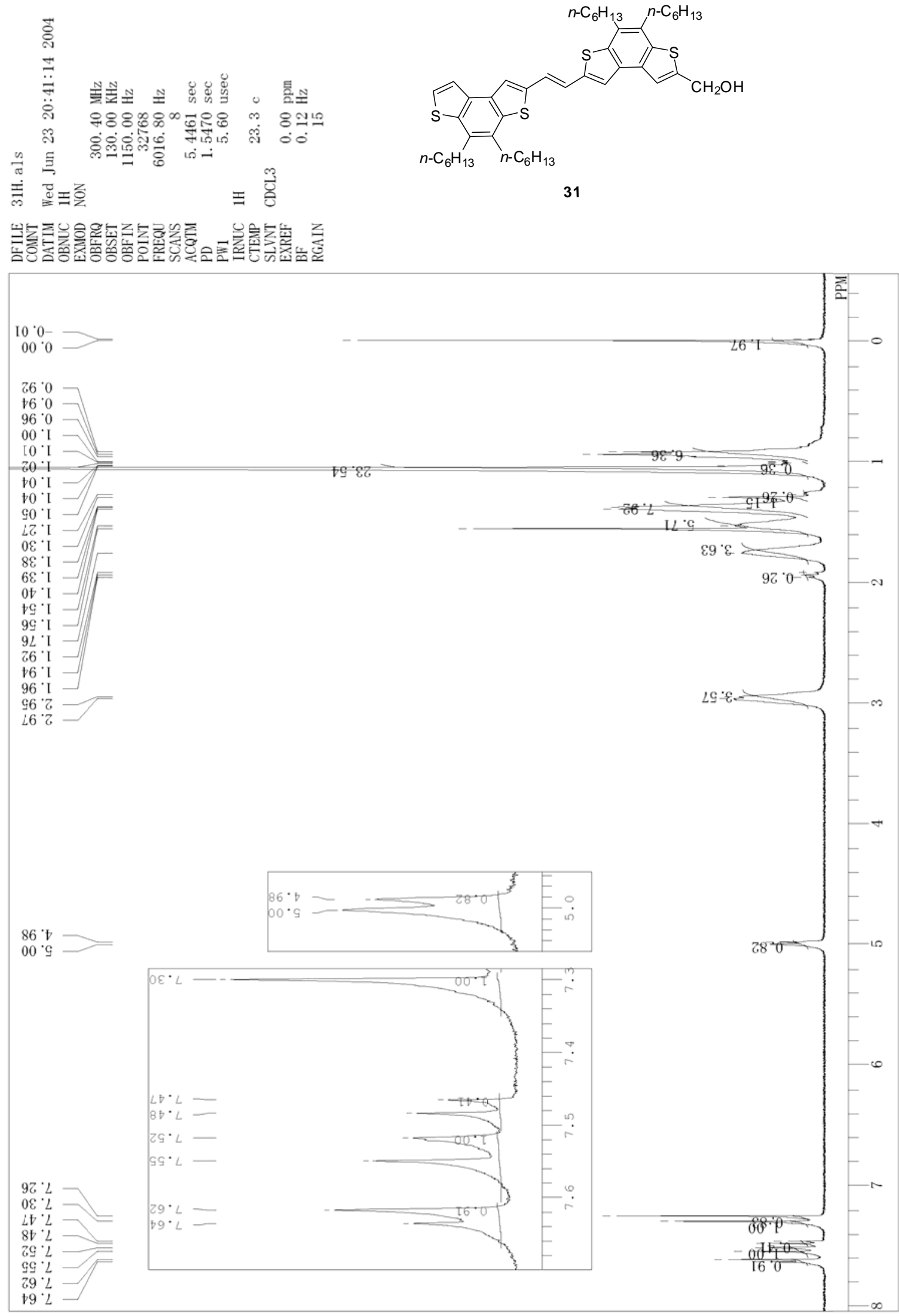



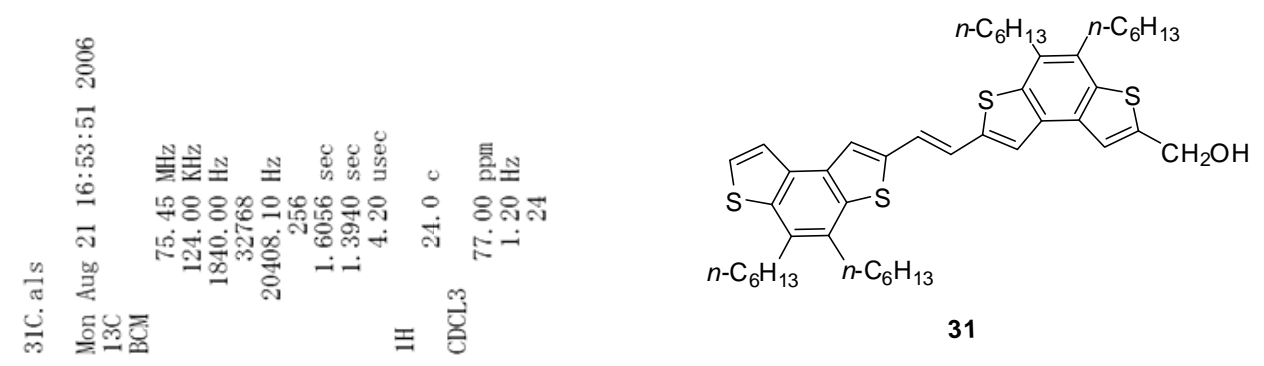

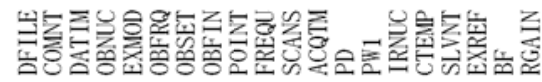

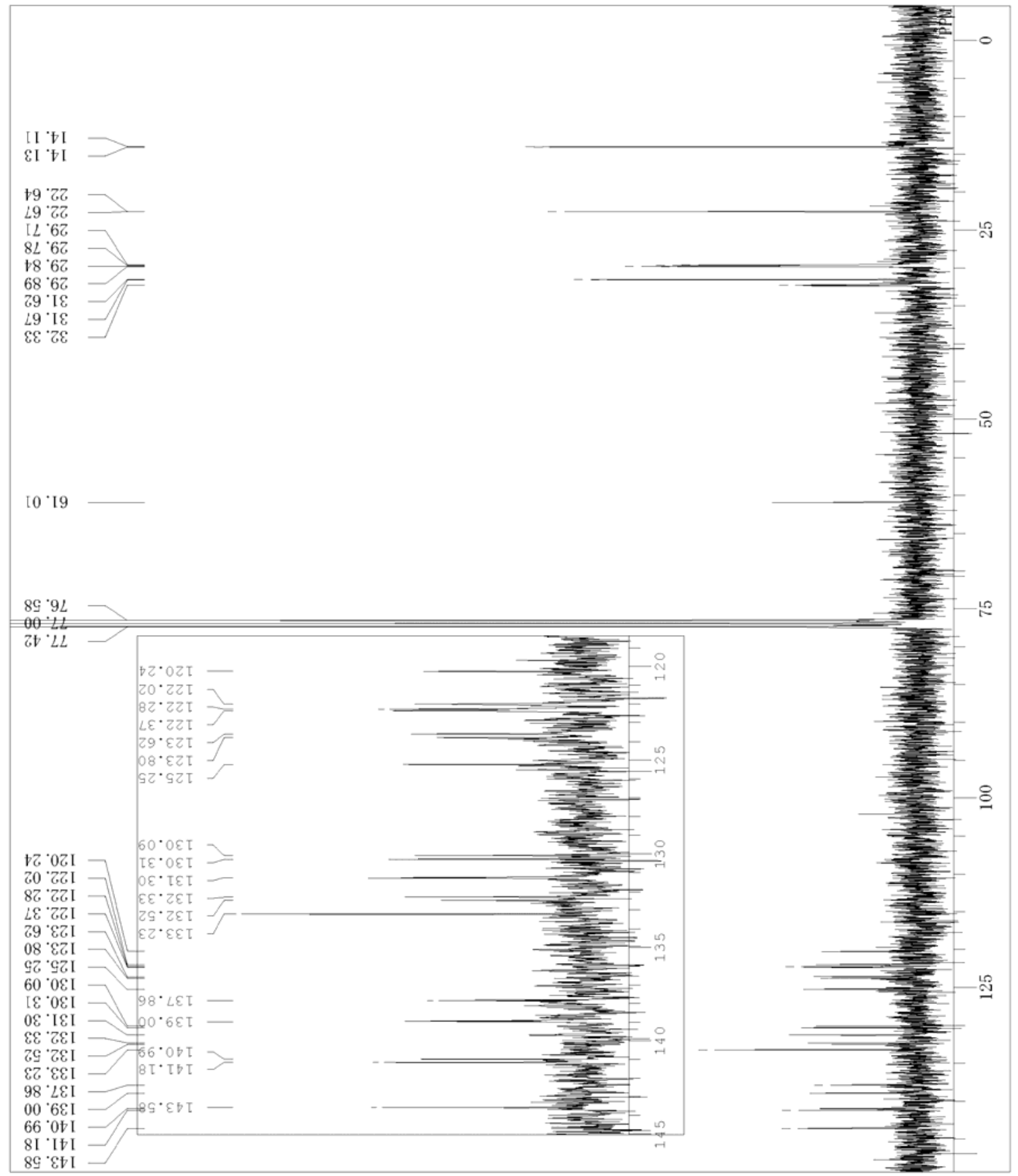




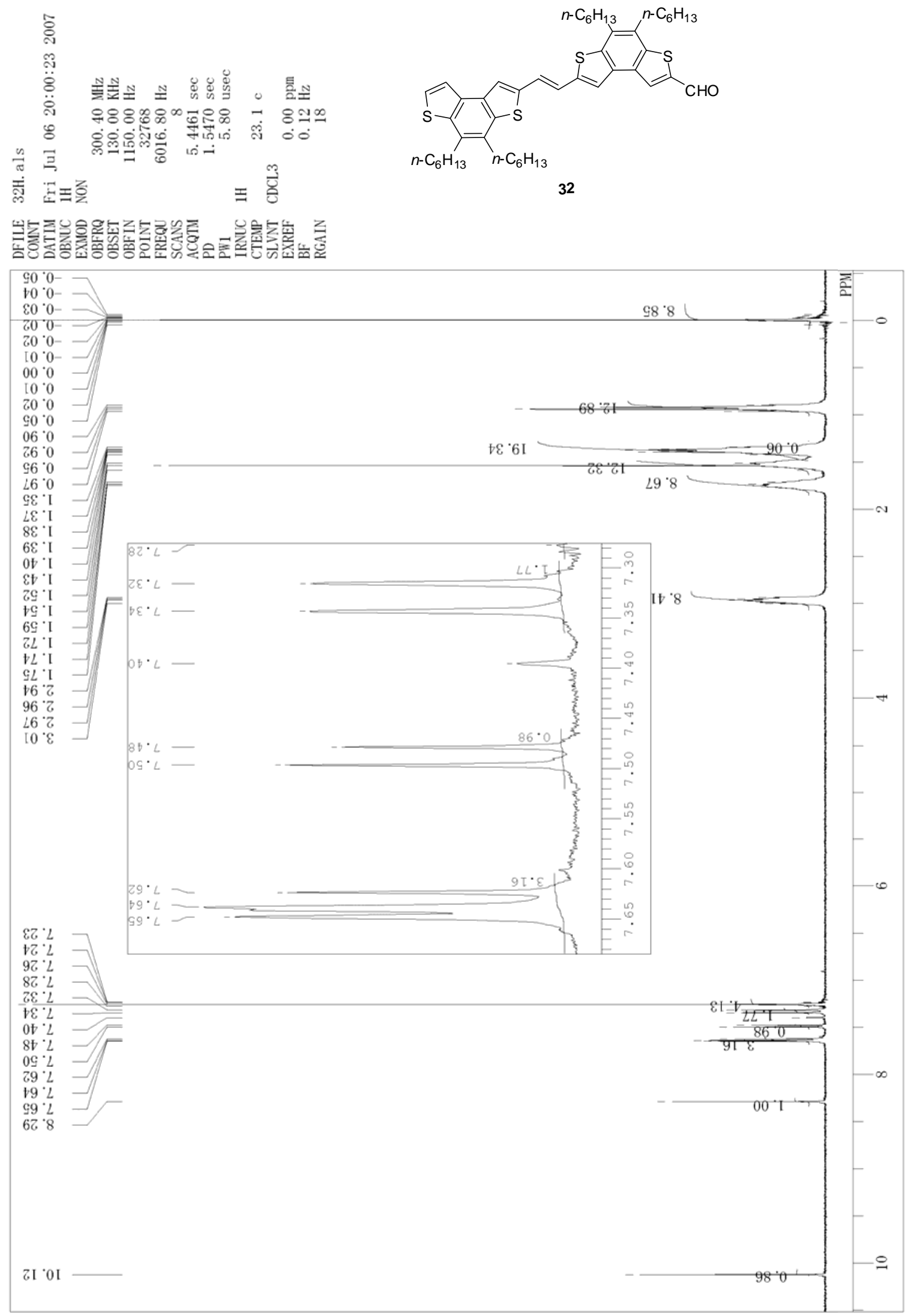




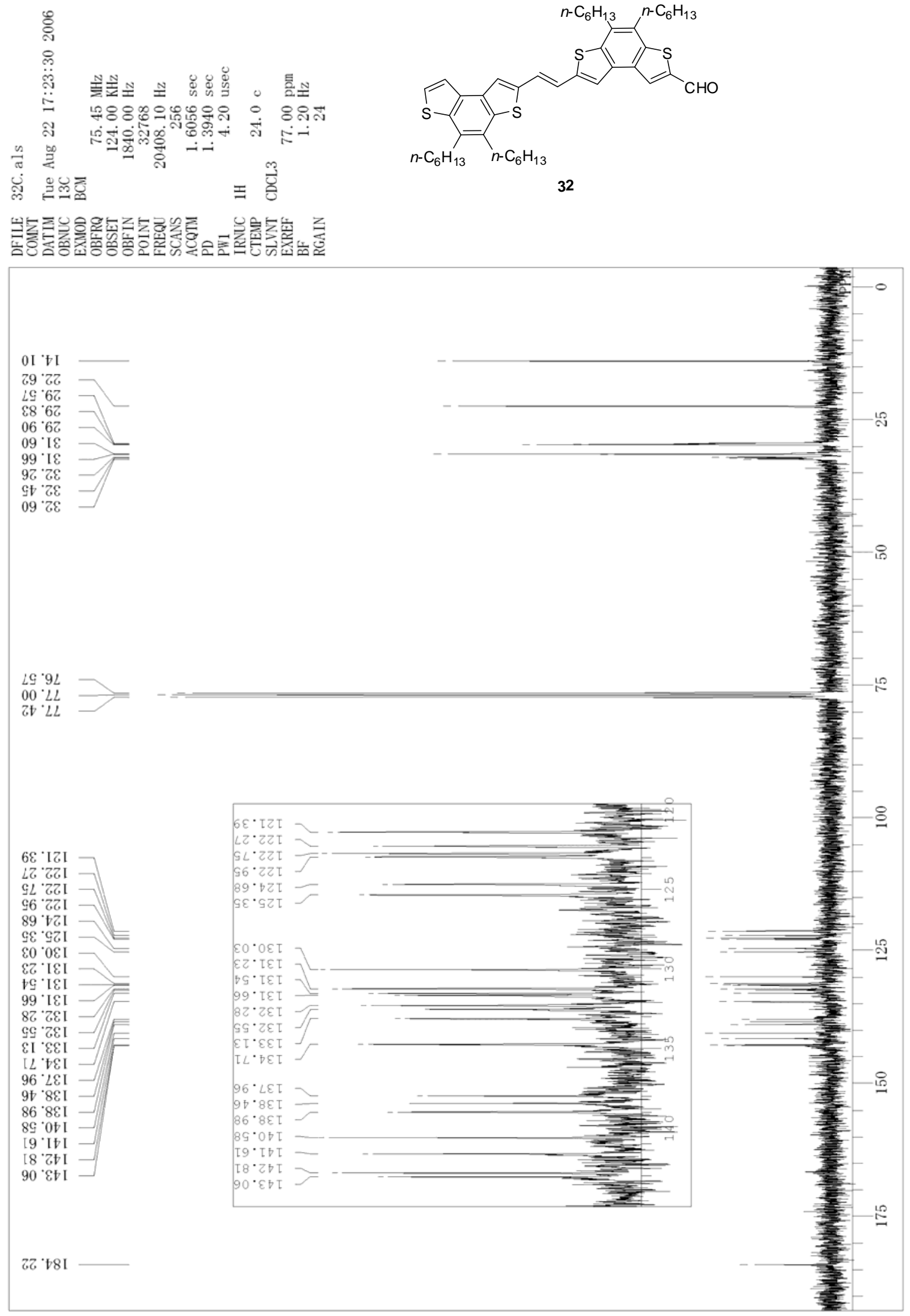



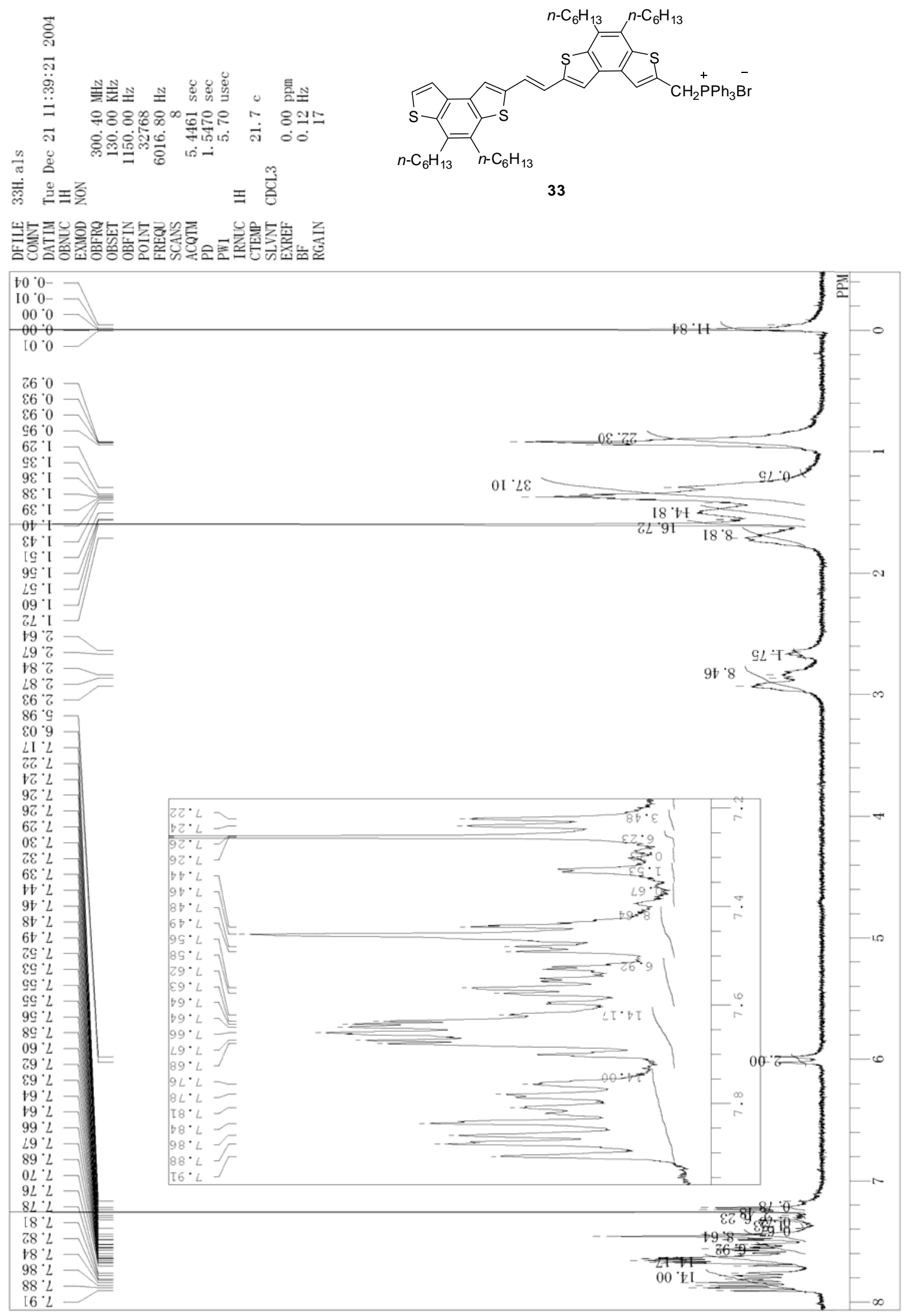


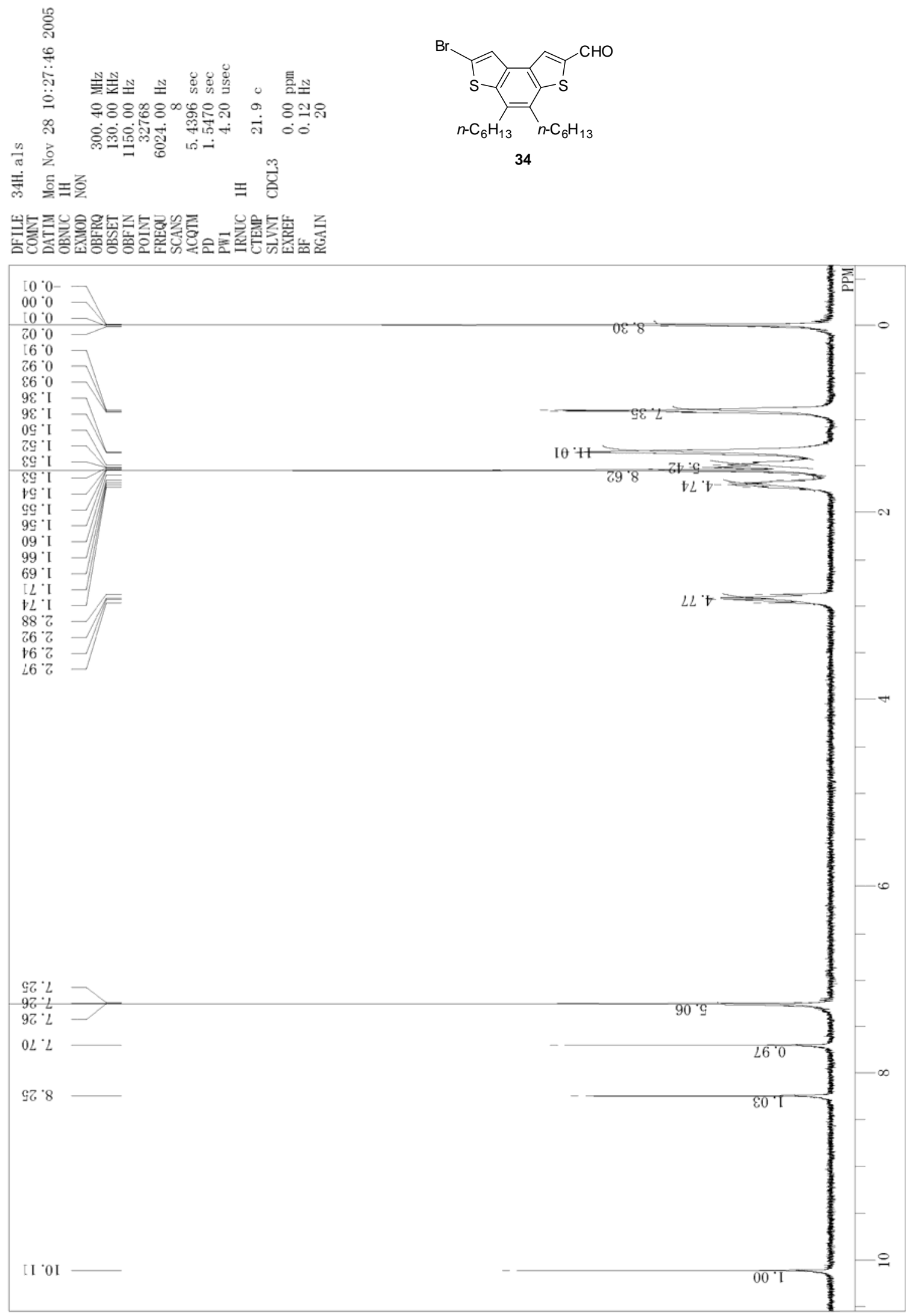




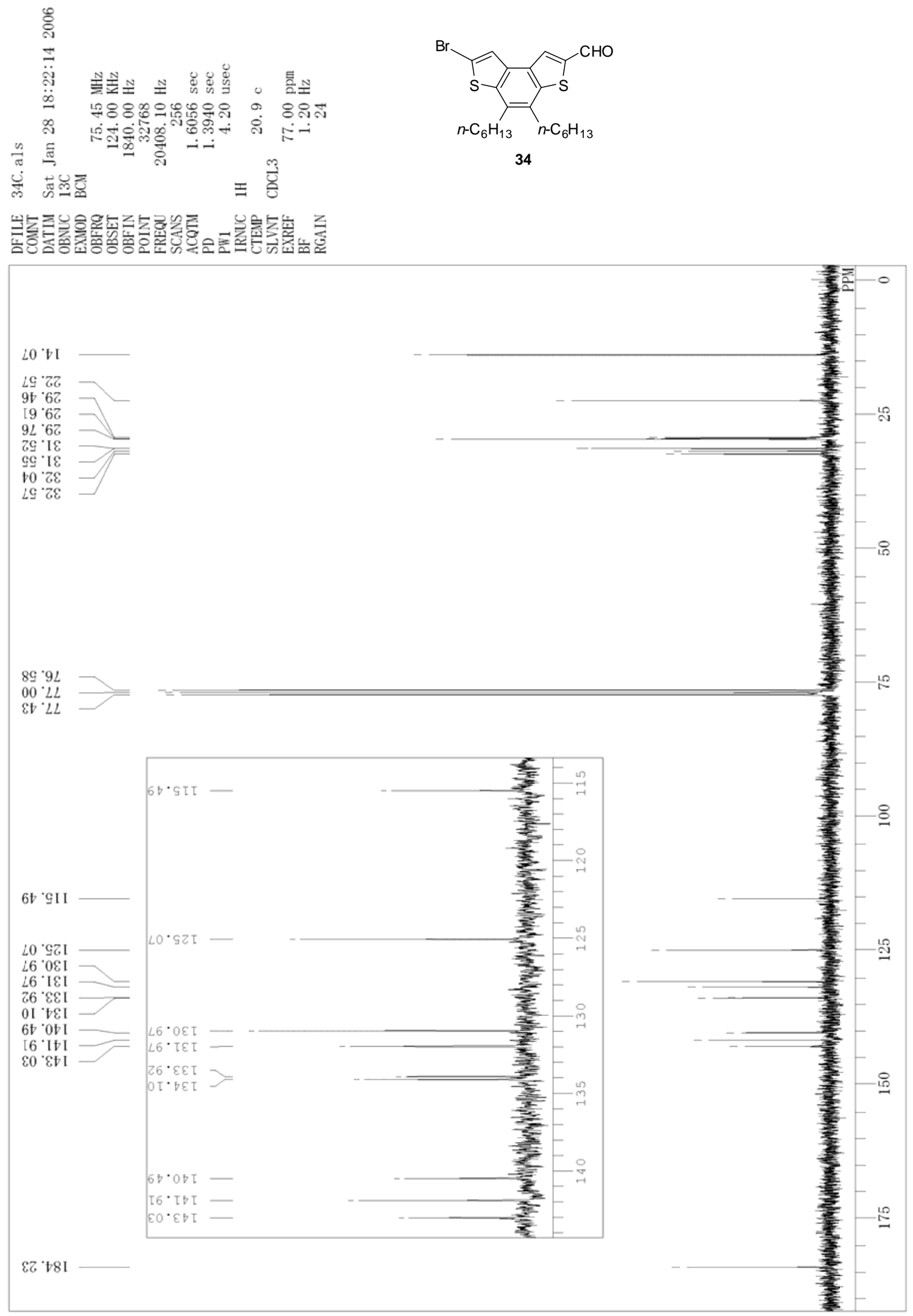




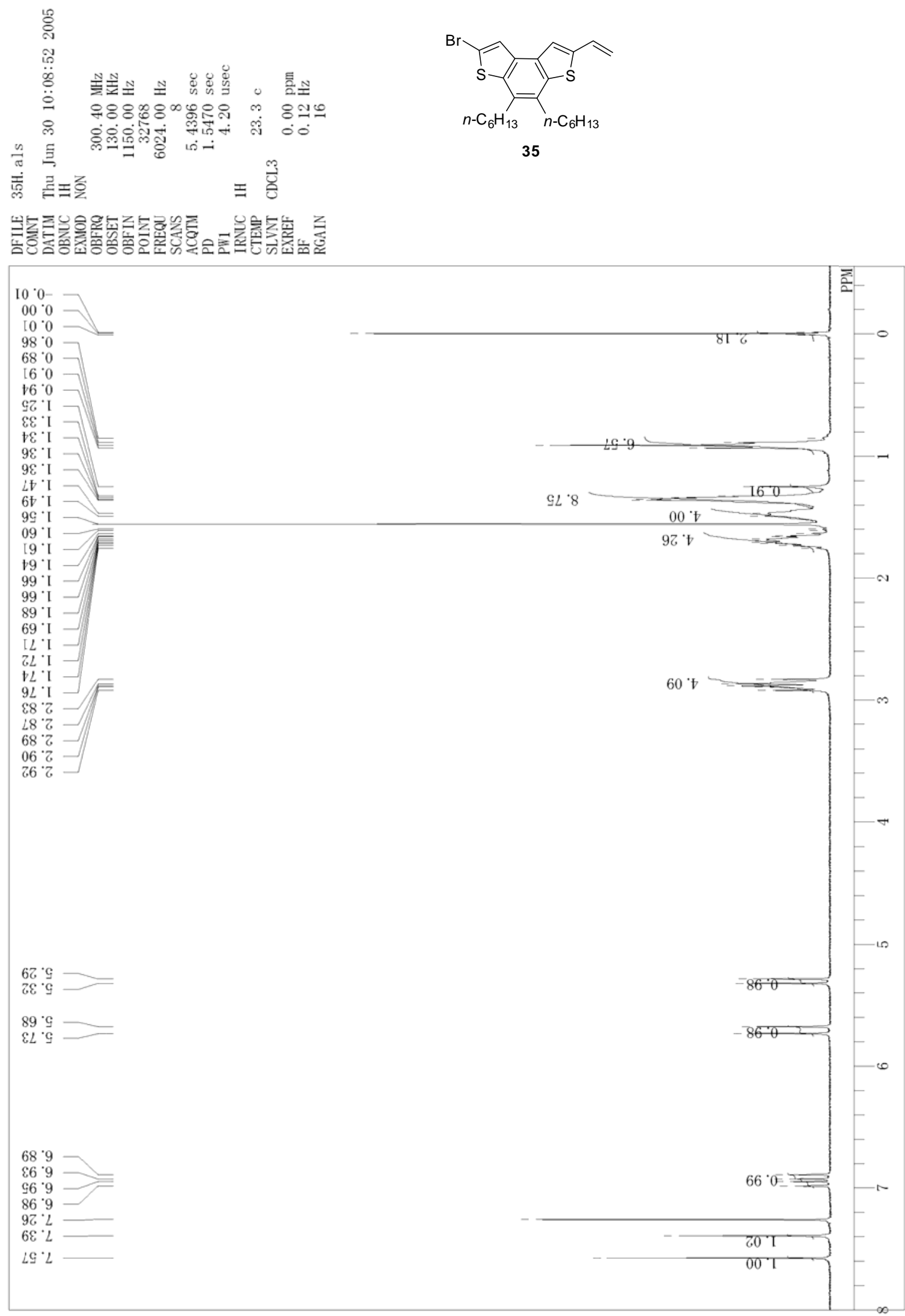



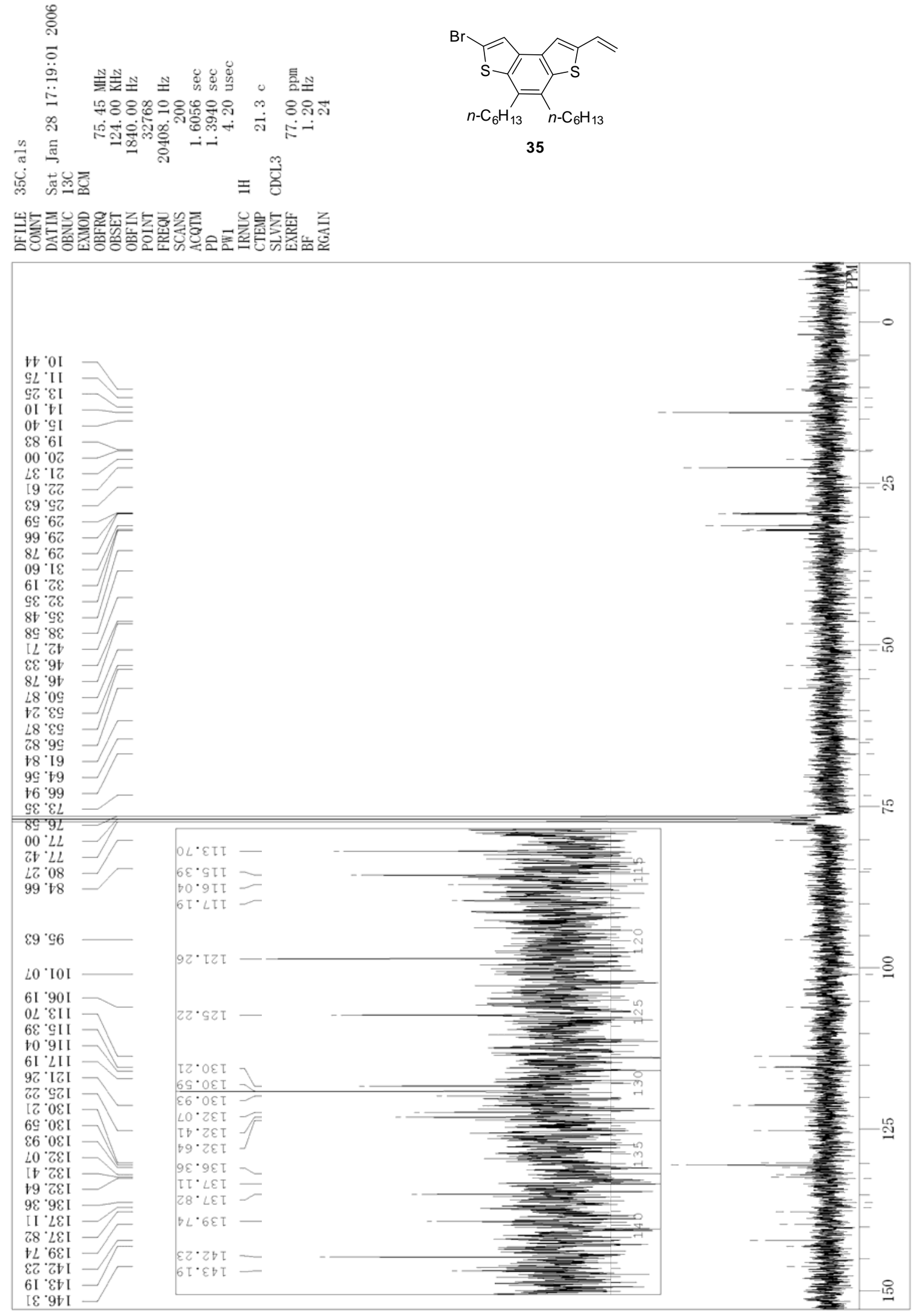


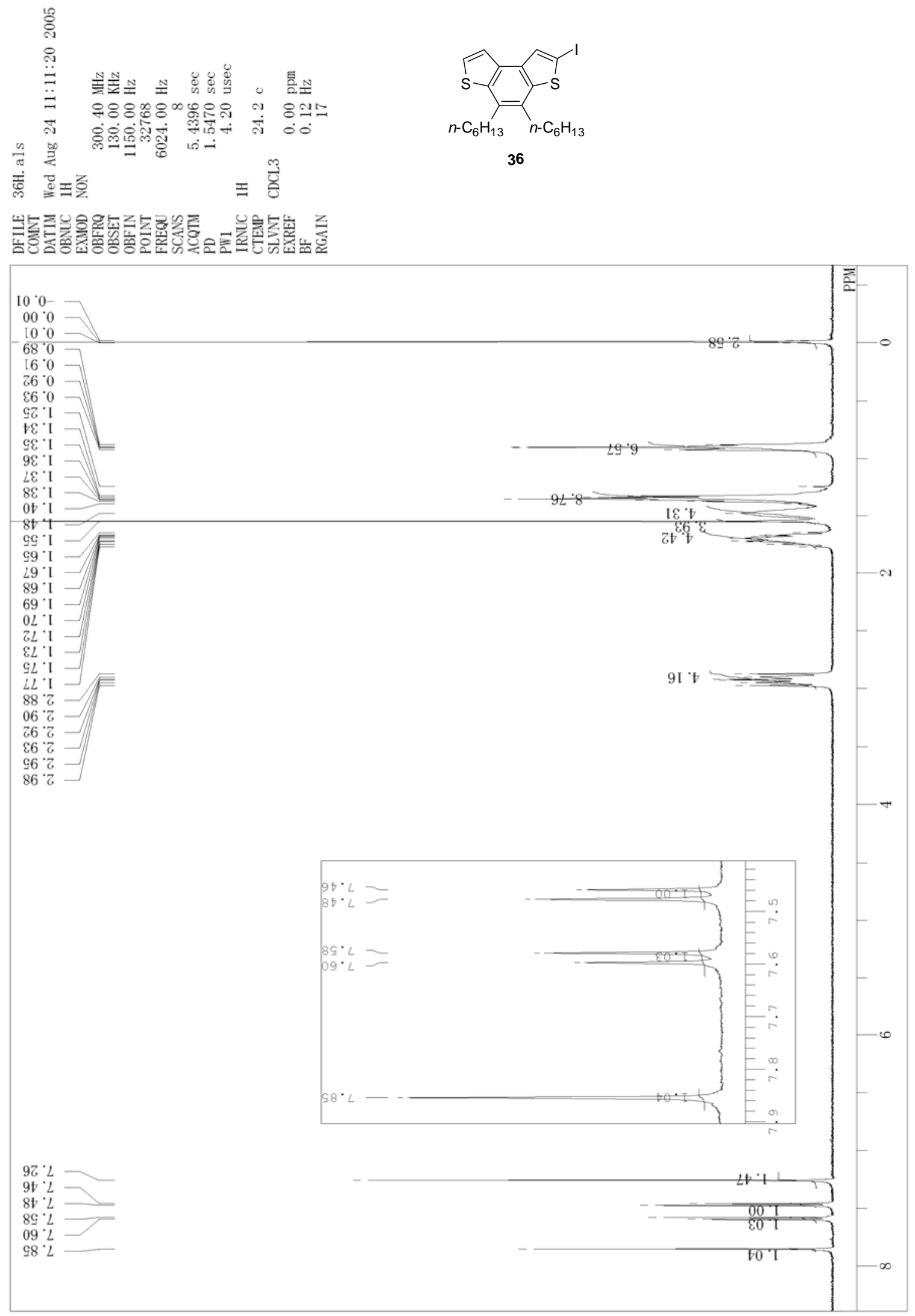



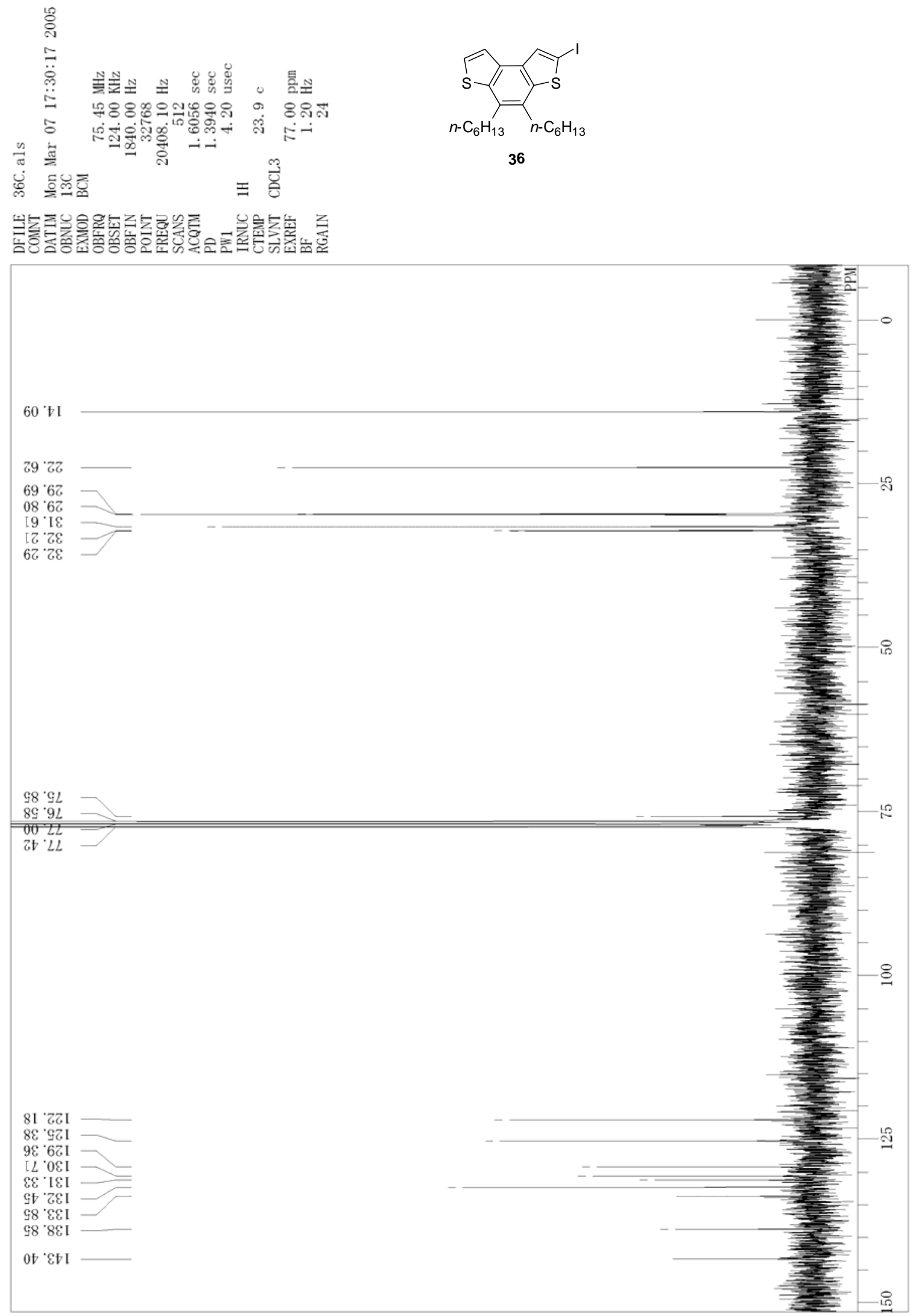

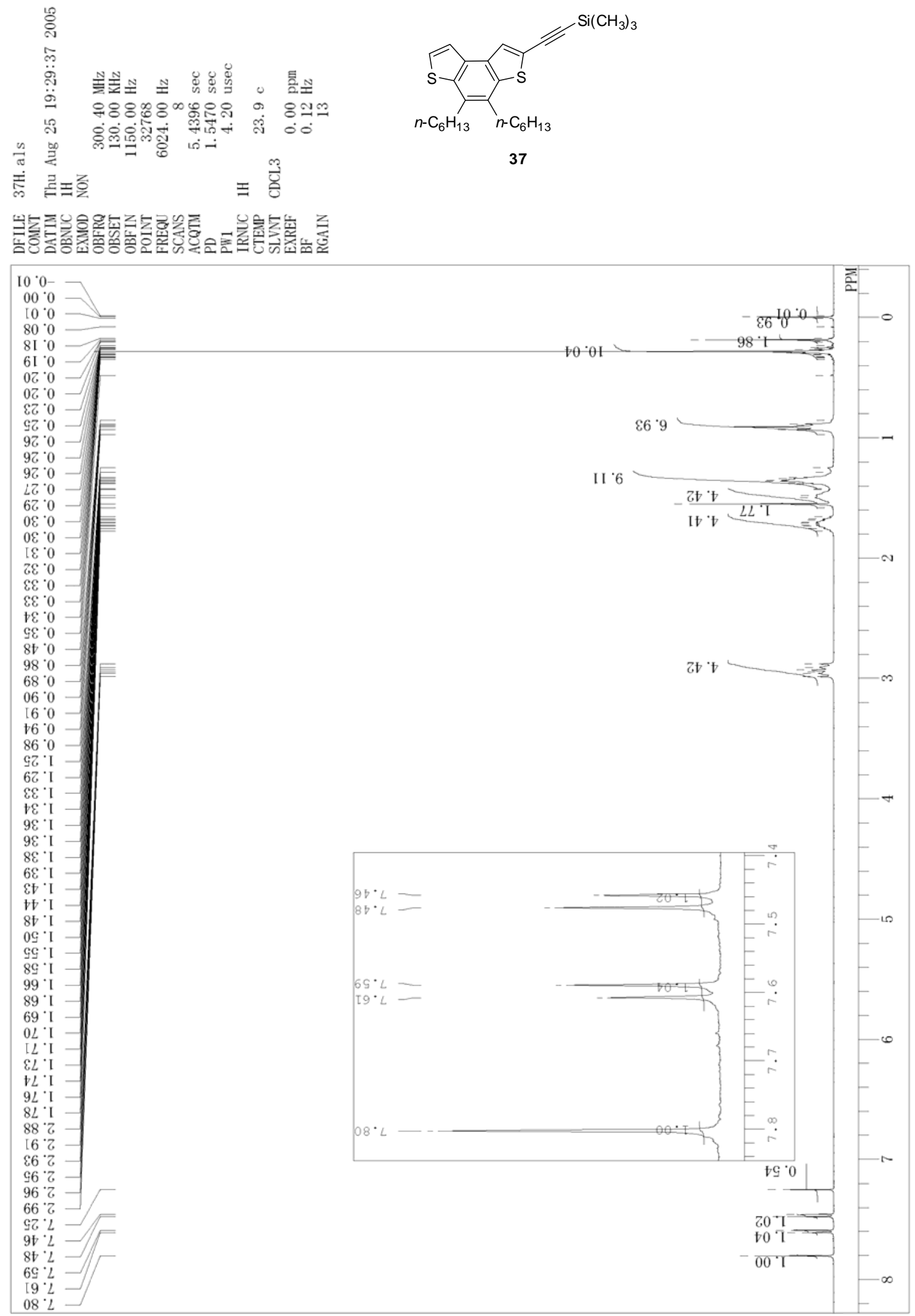


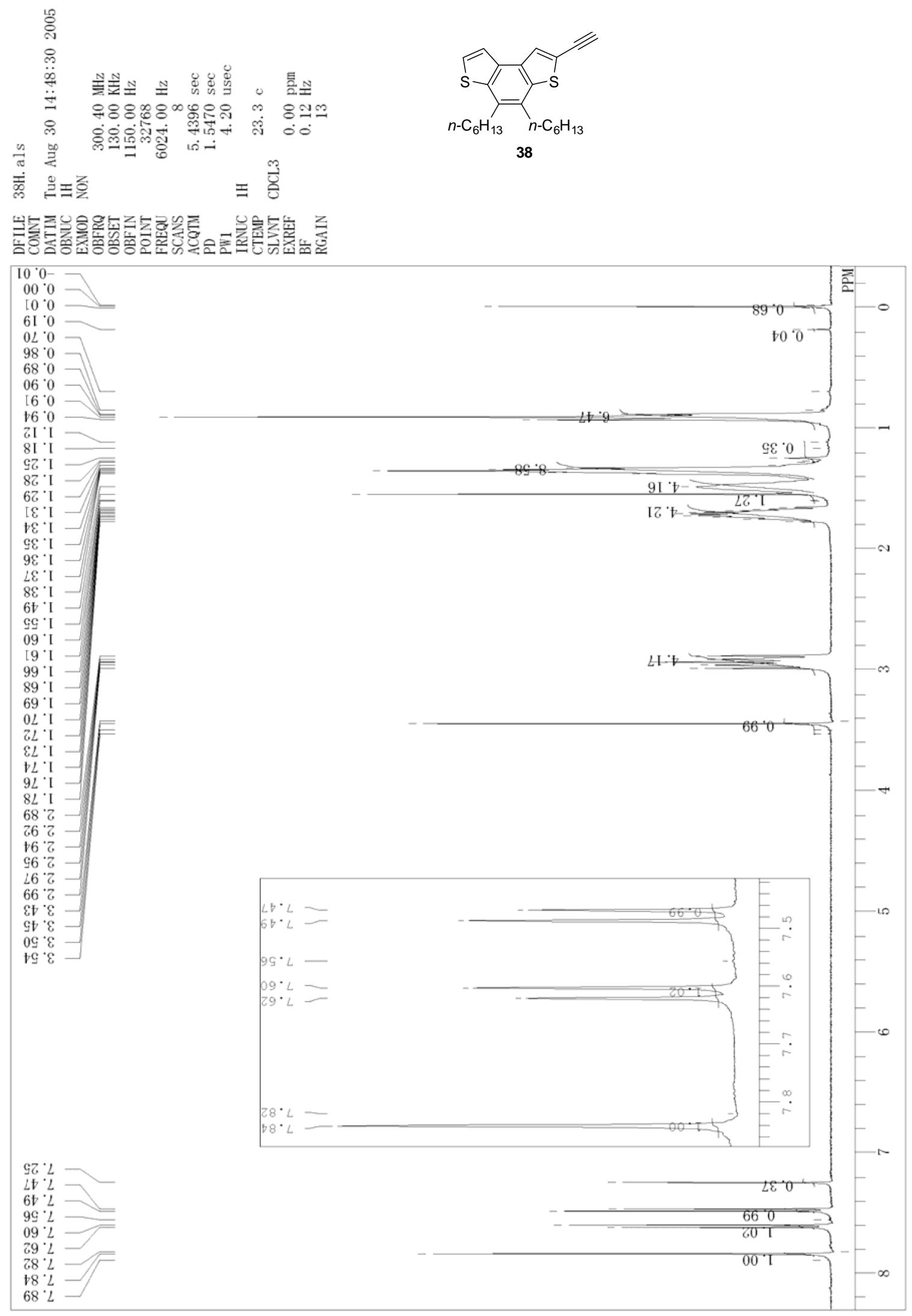




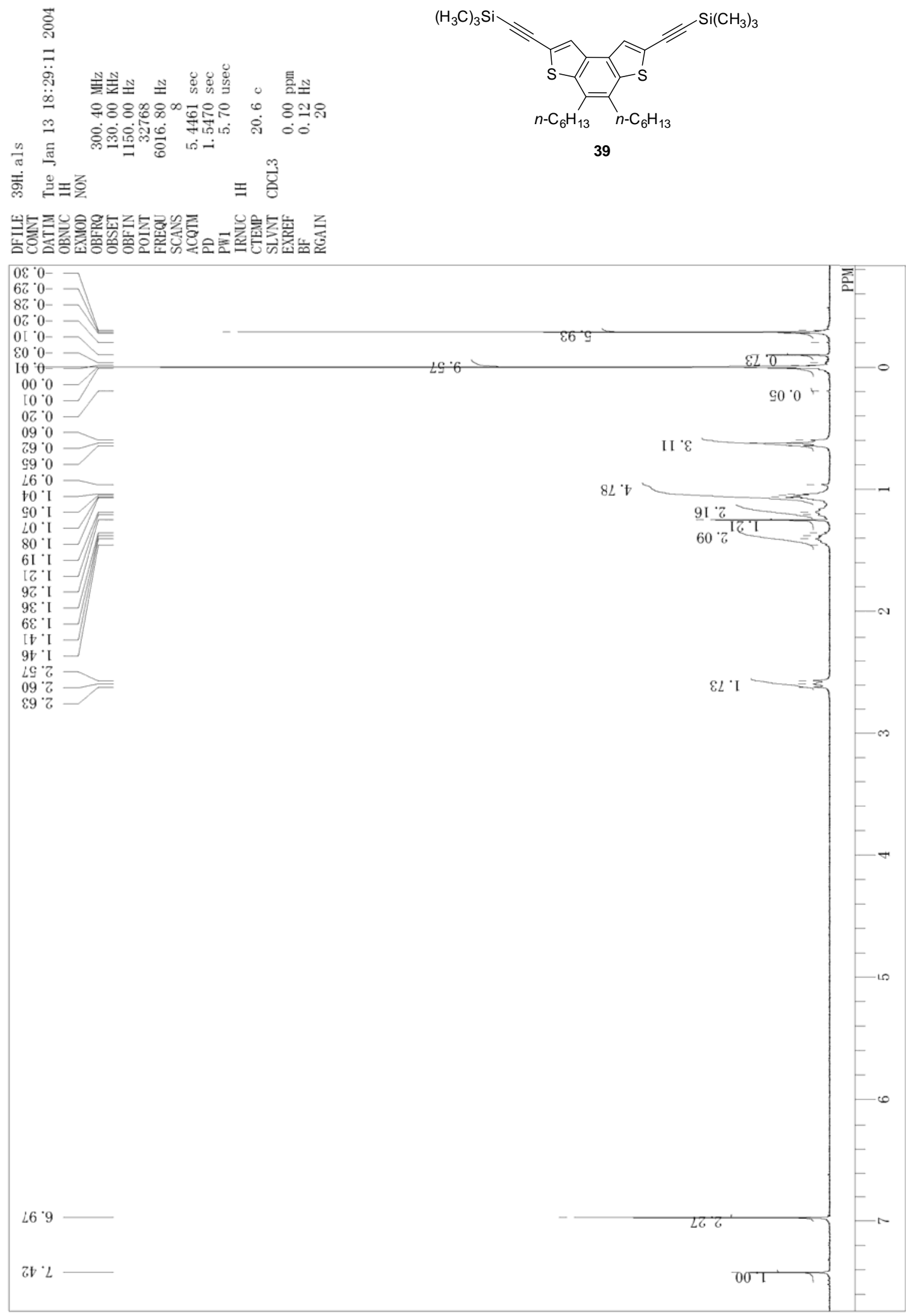




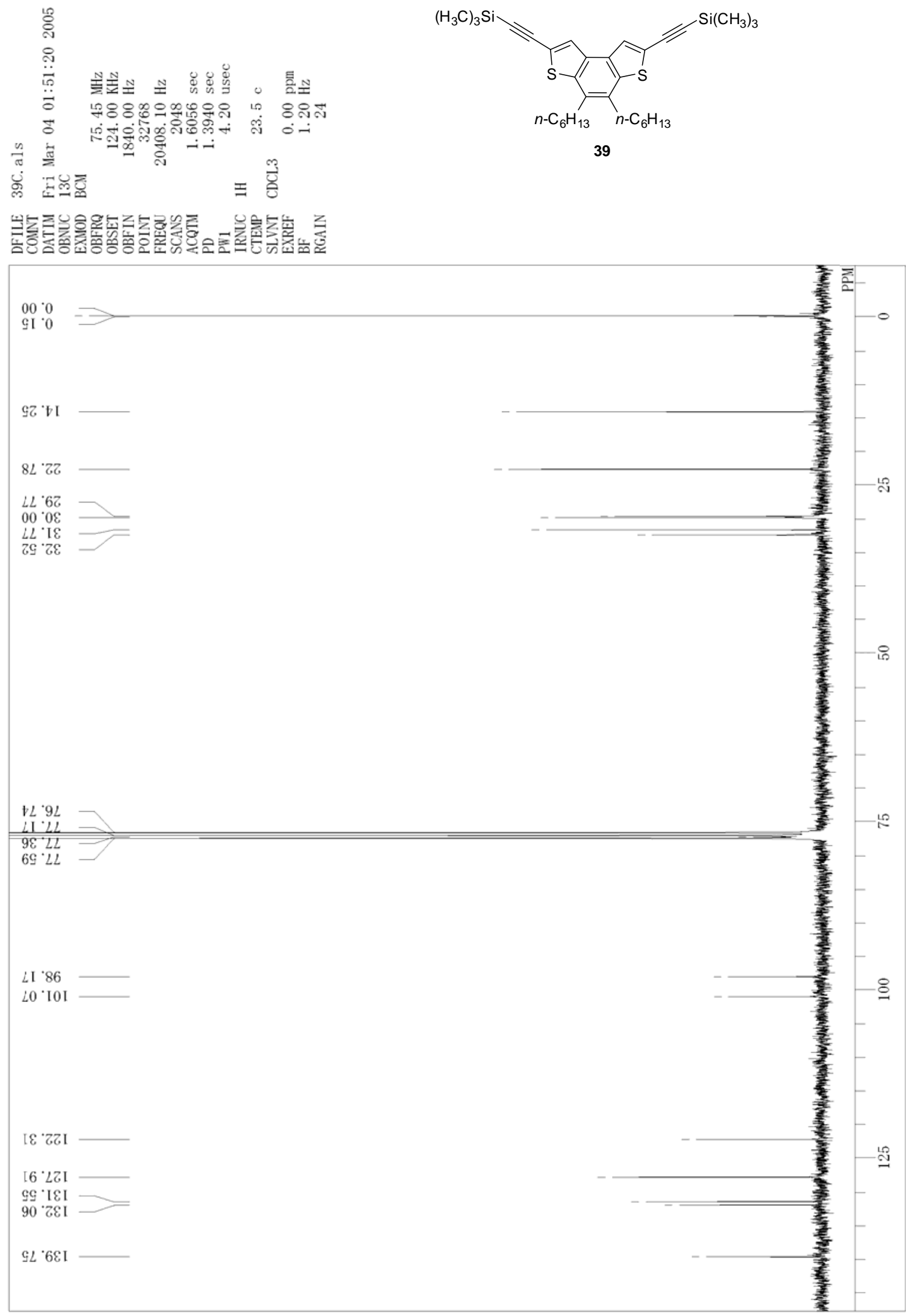




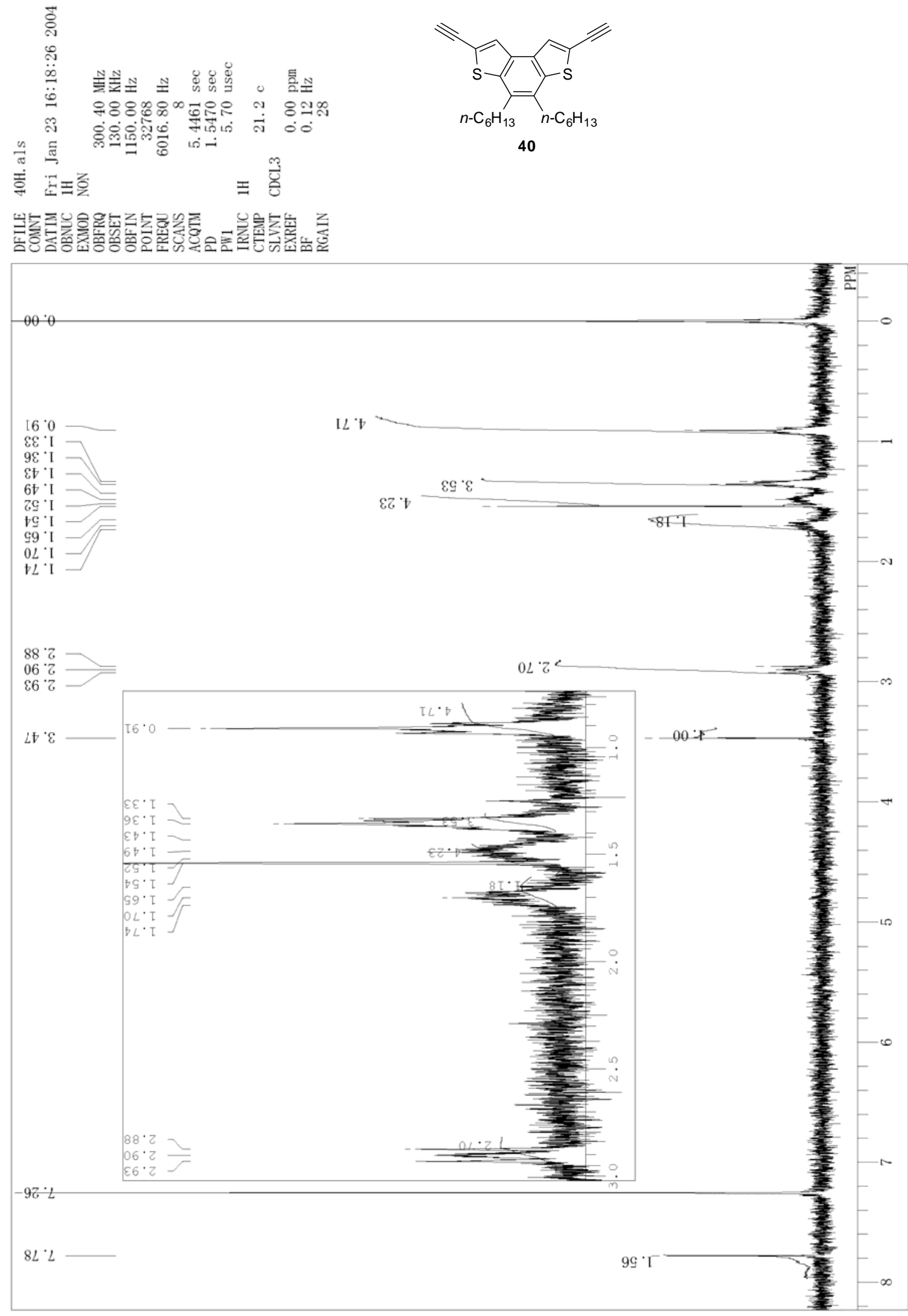




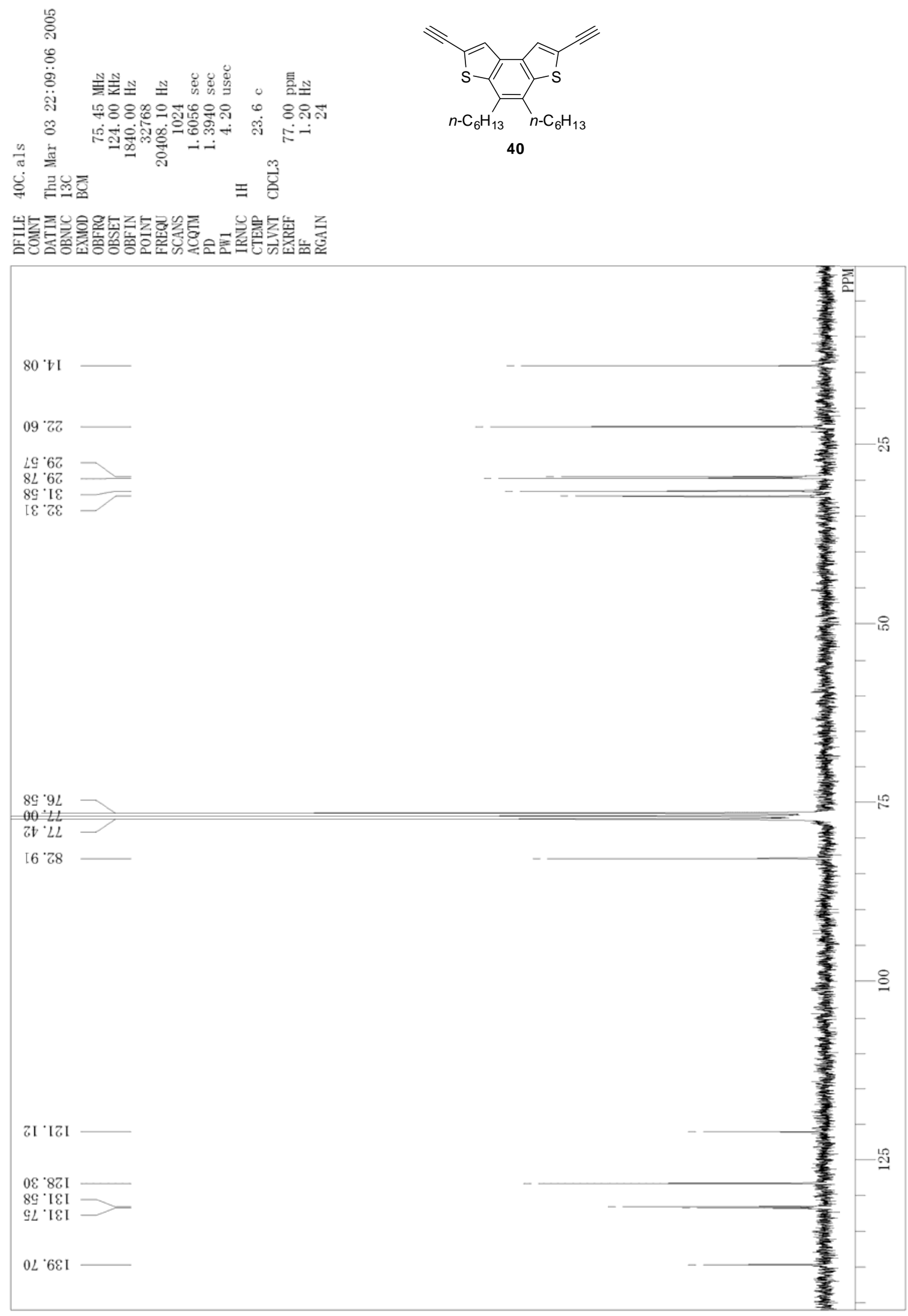




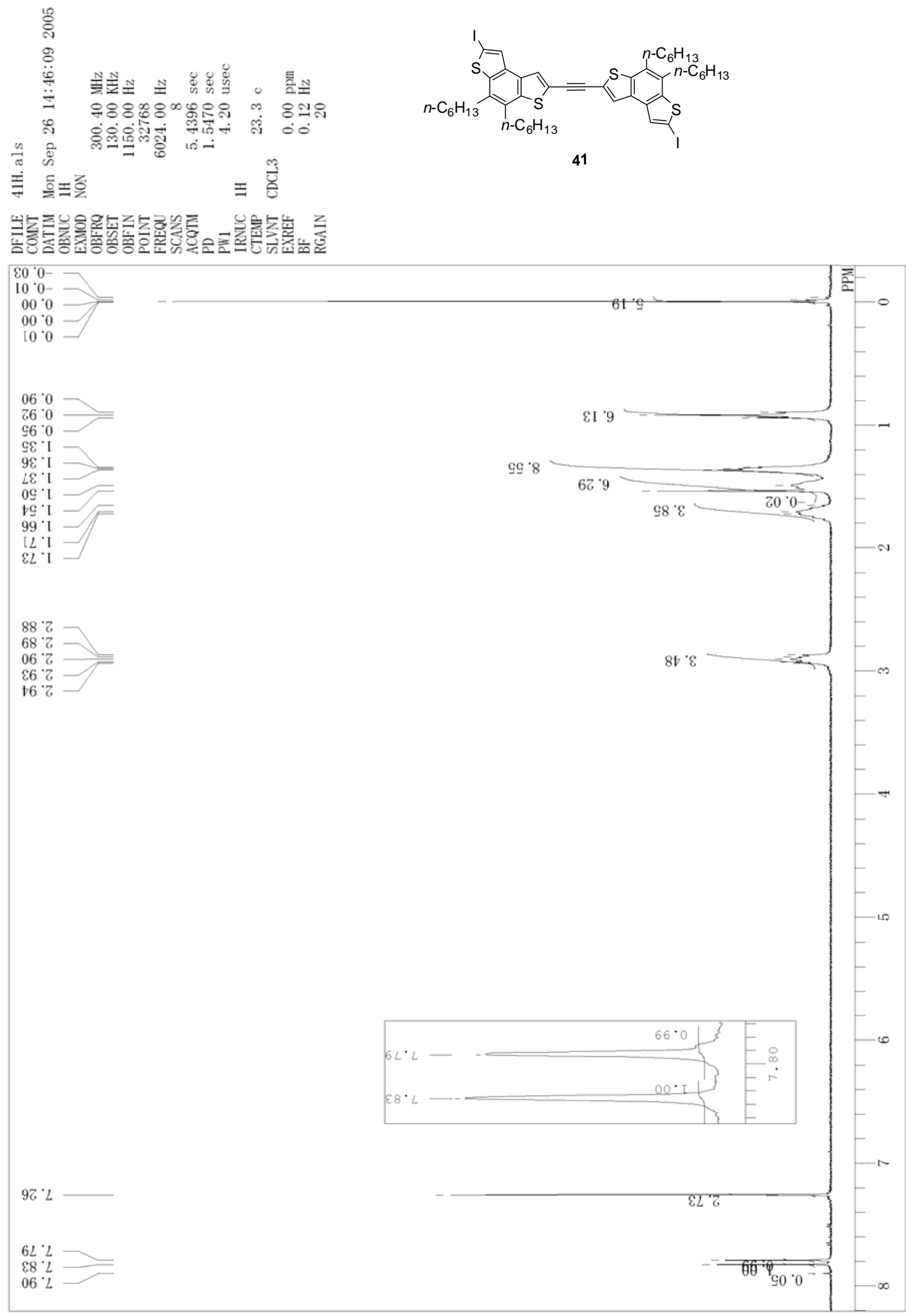

